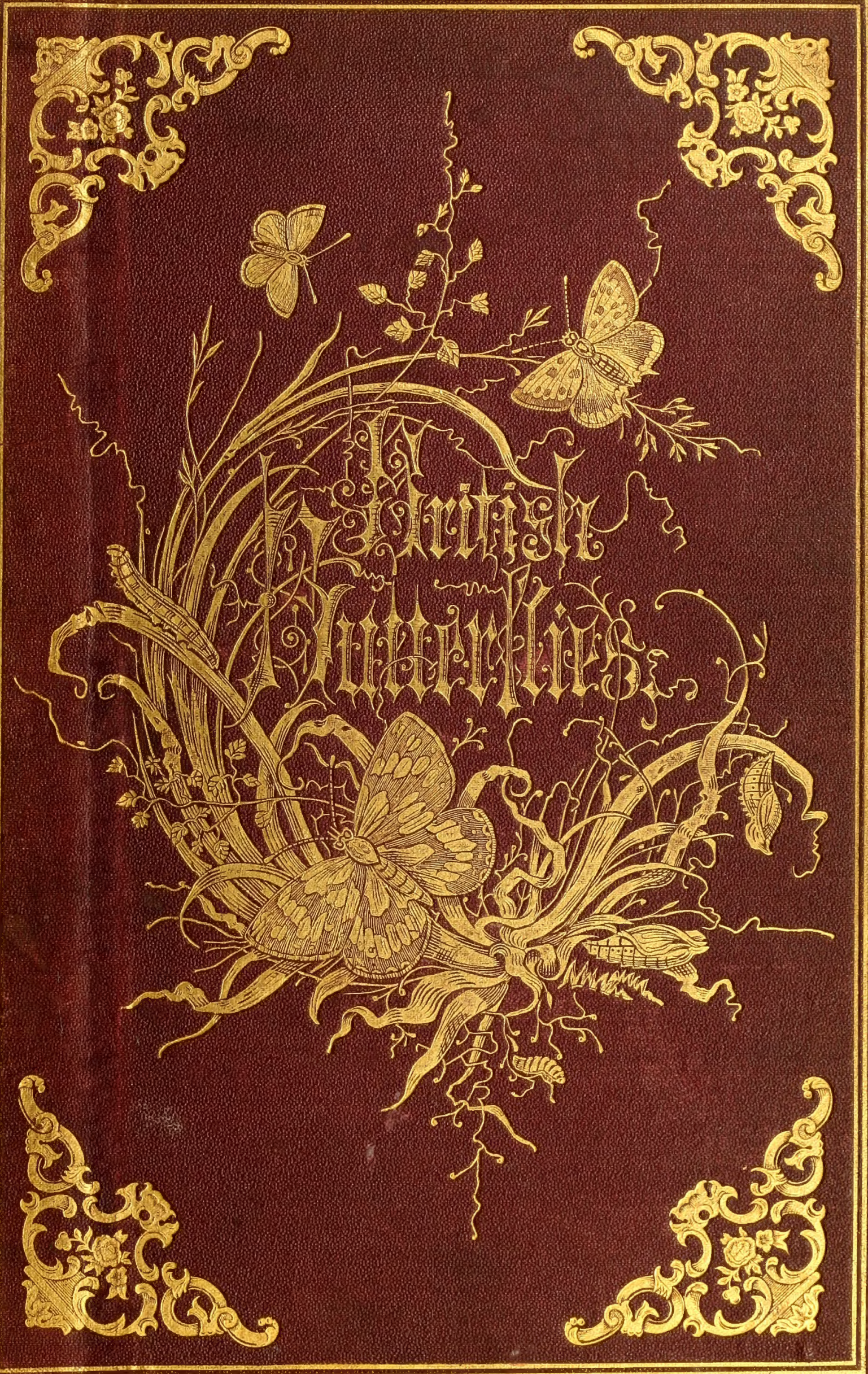







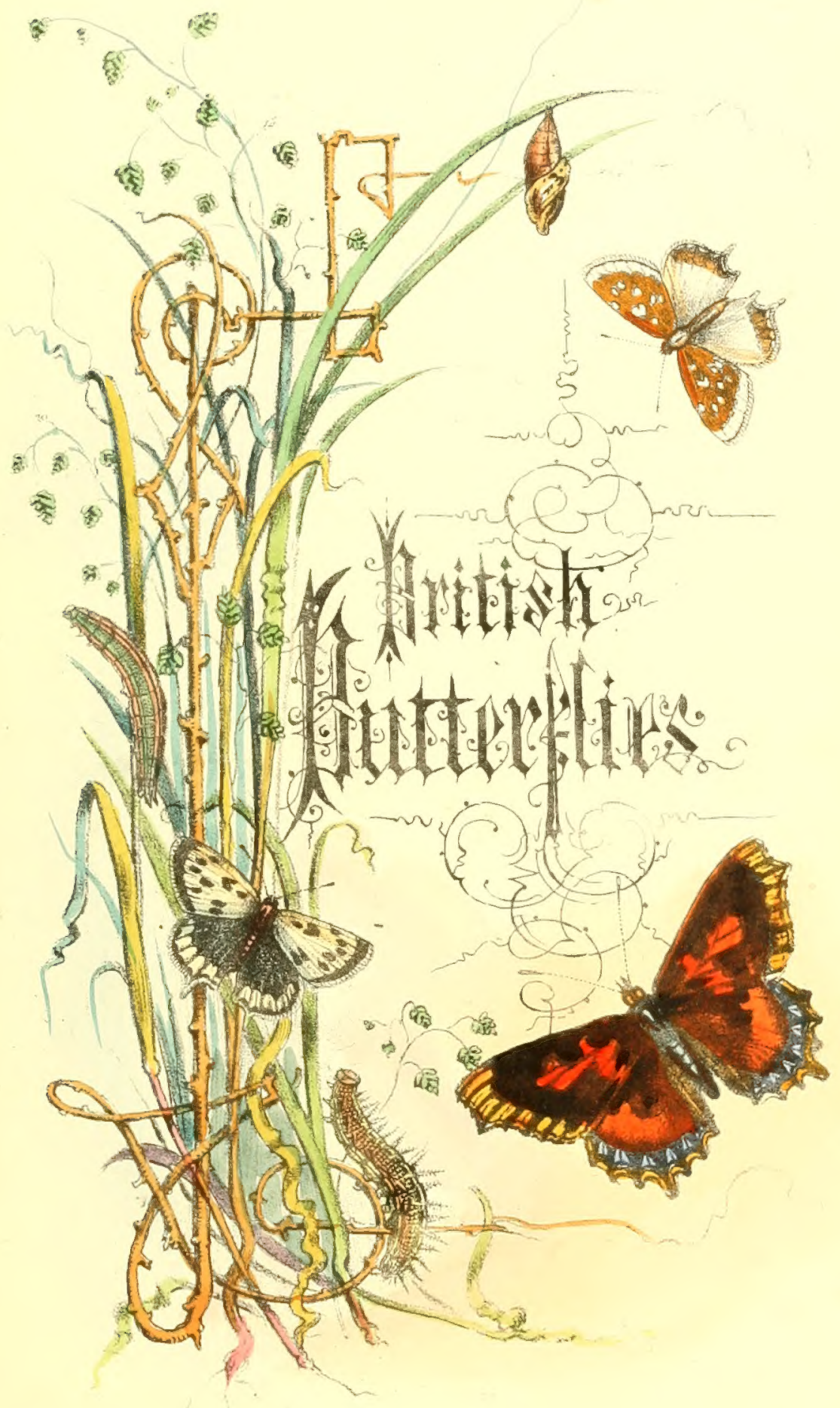





\section{GENERA AND SPECIES}

DESCRIBED AND ARRANGED ACCORDING TO THE SYSTEM NOW ADOPTED IN THE

BRITISH MUSEUM.

\section{H. NO E L H U M I REYS,}

AUTHOR OF "THE GENERA OF BRITISH MOTHS," "INSECT CHANGES," "THE BUTTERFLY VIVARIUMP," ETC.

ILLUSTRATED BY PLATES, IN WHICH ALL THE SPEOTES AND VARIETIES ARE REPRESENTED, ACCOMPANIED BY THEIR RESPECTIVE CATERPILLARS, AND THE PLANTS ON WHICH THEY FEED.

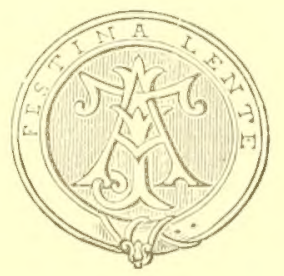

L ONDON:

T. J. A L L M N, 463, OXFORD STRET. Accordingto Horn schenkling - 1859 
BILIING, IRINTER, GUILDFORD.

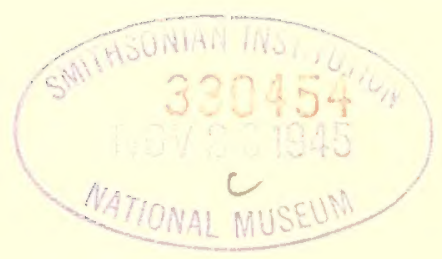




\section{PREFACE.}

WHEN I first became a collector of Butterflies, the pursuit was much less common than now ; and few works upon the subject, in a popular form, existed; so that as my cabinet increased I began to find the want of some instructive manual, in which the distinctive characters of the different kinds of British Butterflies were not only described but also exhibited, by means of coloured representations of all the species, each of its natural size, and accompanied by their respective larva. Finding that no such work then existed, I determined to produce one myself ; and, obtaining the aid of one of our most eminent entomologists, J. O. Westwood, Esq., I published, with his valuable assistance, a volume which I entitled "British Butterflies and their Transformations."

The work was well received, and its sale has exhausted several editions. It undoubtedly did its part, however small, in extending the general taste for entomological studies; but as the circle of students became wider, it appeared to me that a work of less bulk, and of more popular character, might be serviceable. I therefore deemed this a fitting time for remodelling my subject, more especially as many changes have taken place in the mode of classifying our native Lepidoptera. With this view I have undertaken the present work, which, while it will be far less voluminous than the former one, in as far as the text is concerned, will yet contain a greater number of coloured representations of our British Butterflies, of which no single species, or even striking variety, will be omitted, and all the new species and varieties of recent discovery will be introduced.

Without sacrificing anything, as I hope, of scientific accuracy, I have sought to render the present work, and its subject, more attractive by exhibiting the insects in picturesque groups, flitting among the foliage and flowers of their native haunts, or hovering over plants upon which the larve may be seen feeding. I imagined that by thus presenting our indigenous Butterflies to the notice of the student under a natural aspect, instead of displaying them in the form of dried specimens, as stiffly pinned out in a cabinet, my volume might possess the advantage (as an introductory work) of attracting many towards the study of this branch of Natural History who might be repelled by a more dry and technical arrangement. I mean such as generally characterises entomological works which have any pretension to a regular and comprehensive character; or such as embraces (as in the present instance) the complete treatment of any special section of the science. 



\section{THE INSECTS ON THE TITLE PAGE.}

Tot hiving found space to sive many representations of mere "varieties" in the preceling Plates of British Butterflies, I lawe introlued in the Adlitional Title Page there of the mest remarkable that occur among our native species. The largo insect in the lower part of tho page is a rich and very beautiful variety of the common $V$. Urtice, which differs in several particulars from any variety I have previously met with (see page 27). It is in the possession of W. P. Russell, Esq., of Monks Eleigh, Suffolk, and was obtained cluring the season of 1859. From the drep cream-rolumed borlering of the anterier wings, and the lisinosition of the darte bromblylack to fill up nearly all the remainder of the fore-wings, it appears probal, le that it may be a liybrid between $V$. Urtice and $V$. Antiopa.

Above the variety of $V$. Uitica are two of the remarkable varicties of $C$. Phlcas (the Small Meadow Copper), which occur in certain localities not unfrequently. In the lower of the two

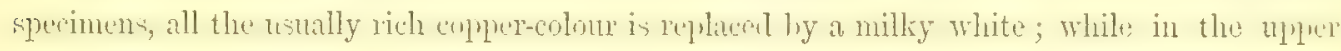
one it is the black that has disappeared, leaving white in its place. (See page 46). 



\section{IN TRODUCTION.}

ALt the tribes of insects necessarily excite our wonder and admiration, either from the striking metamorphoses which they undergo, or by their curious structure, or the intricacy of their form, or splendour of colour; but none arrest the attention of the tyro so soon as the beantiful and distinct class, lmown as Butterflies or Moths. The large size of the exruisitely constructed wings of this tribe of insects-so great in proportion to their generally slender bodies-and the exquisite traceries, often in the richest hues, with which those wings are decorated, render these insects at once conspicuons to the most inattentive observer.

This may be said more truly of the Butterfly than the Moth family, inasmuch as the wings of Butterflies are generally much larger and more splendidly coloured than those of Moths; and also because Butterflies fly by day, disporting in the bright sunshine where they cannot fail

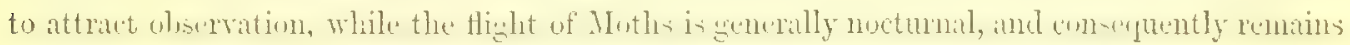
unobserved except by the experienced stulent.

To pursue the detail of characteristics which distinguish Butterflies from Moths, I may call attention to the exquisite rariety of colouring with which the under surfaces of their wings are decorated, often of totally different character to the markings of the upper side. In the class known as the Coppers, for instance, the upper surface of the wings is of a bright metallic scarlet, sometimes without spot or mark, while the under side is of a soft pearly gray; profusely dutted orer with cyclike circlets of white surpumeling a black sut or pupil. In Mother, on the other hand, the under-side of the wings generally presents but a pale reflex of tho markings of the upper surface, and in no case are they of remarkable beauty as with many kinds of Butterflies.

Another distinction between these two closely related families of insects is the different markings of the wings, which occur in the two sexes; these are so distinct, and sometimes in both cases so beartiful, as to have led even the great Linnous himself, in the comparative infancy of the science of Entomology, to mistake the male and female of the same kind for distinct species. As examples of this disparity I may cite the little blue Butterfly, known as the "Cliften Blue," in which the wings of the male are of a lovely azure, while those of the female are of deep brown. Then there is the common white Butterfly of our gardens, linown as the "Garden White," which in the male sex has the beautiful creamy white of the wings perfectly immaculate, except at the dink tips, while in the wings of the fenald there are two large and very conspicuons black spots near the centre. In Moths, on the contrany, scarcely any distinction exists, in the markings of the wings of the respective sexes, though other distinctions still more singular distinguish them in that section of the family, but which to not call for detail in this place. 
A somewhat remarkitile distinction hetween Butterflies and Moths is that exhibited respectively by these grumps of insects when in repose; the Butterfly sitting with its wings raised face to face orer its hack, while the Noth allows its wings to fill on each side towards the suhstance on which it is resting, anch in this position they remain with the upper siles in full view, which, from the internal edges, slope ontwarls with alsout the inclination of an ordinary roof.

Still another elistinction, and one which has served as the basis of the scientific line of separation, is the form of the homs, or antenne, which in the Butterfies are invariably furnished with a small club-like appentage at the extremity, while in Moths the antenme are always more or less pointerl at the encl.

In the preparatory and snccessive states of erge, caterpiliar, and chrysalis, common to both Moths and Butterflies, the distinction is only strikingly renarkable in one stage, that of the chrysaliz. The erencral aspect of the eng and caterpillar being in many cases so similar, that muless from positive knowlulge of the species, it wonld be diffienlt to decile at a glance, whether they were the exes and caterpillars of Moths or Butterflies; hut in the chrysalis stage the ansular forms and light colonring of the Chrysalides of Lutterfles at once dintinguish them from those of the Mrothe, the conical forms of which are generally smooth, and almost invarialily ilark.colonrext.

$\Lambda$ characteristic to be especially noted in these interesting insects, and perhaps the one most intimately connected with their preculiar beauty, is common to both. Moths and Butterties, and distinguishes them from nearly all other insects. I allude to the beantiful fuather-litse scales with which fleir wings are invariahly clotherl on the upuer surface, and most frecuently on the under surface also. This character, which the two fanilies possess in common, has furnished the scientific title (to be described hereafter) of the "order' to which they are made to belong. It is inleet an amply suflicient distinction, heing a leating and prevailing characteristic, scarcely ever fomcl in any other class of insects. There are, however, some remarkable exceptions; as for instunce, the perfect insect of the Caddis-worm, a creature very closely resembling a moth, which has the wings closely clothed with a precisely similar kind of scales; aud some other examples might he cited, though not in sufficient mmler to invaliclate these characteristic scales as an all-suficient means of distingnishing the insect 'order' now under description.

The wings of Jutterflies and Moths may then, for all the purposes of scientific classification, he said to be, colnsively, furnished with a clothing of feather-like scales, to which they are indehted for all their beantiful markings ; for if these coloured scales be carefully brushed away, the naked wings will present, only upon a much larger scale, the general appenrance of those of a common housefly, consisting, as they do, of an excessively thin and nearly perfectly transparent tissue, strengthened by a branching framework of nervures, or veins, as they are more commonly called, which mintains the almost film-like substance distended in an even plane, thus ensuring the form and also the strength necessary to the wings during their exertion in the action of flight.

In order to unclerstand the nature of the entire existence of a Butterfly, it will be necessary to consicler its aspect umler the successive forms or metamorphoses ly means of which its progress to completeness is effucted.

The egg, which is laid hy the female Butterfly in some secure situation, in which the infant insect when hatcled is sure to find abundance of food, is ortinarily of about the dimensionto use a trite comparison-of a pin's lead, of arerage size; and to the naked eye it presents a somewhat similar appearance,-but placed under a microscope, beneath the power of which so many of the mysteries of nature have heen unfolded, it assumes a peculiar and ristinctive form not found in any other class of ceres. The egers of Butterfies and Moths are seldom or never of the usual oral or egg-form; and instrad of being smooth, lilie the egrgs of hirds, they are 
intricately decorated with delicate raised patterns and devices, sometimes extending over the entire surface. These patterns are of almost endless variety in different species. Those of the delicate little moth Gcometra Cratagate are covered with regular geometric network, resemhling a shallow honeycomb. The eggs of one of the brown MLadow Butterflies are nearly splerical, but flattened at the base, and ornamented with rows of minute raised linobs disposed like the segmental marlis in a peeled orange, only closer together. Those of another, of the "Meadow Brown's," are enriched with longitudinal ribs, connected in the lower portion hy delicate horizontal marks, which at the top have the appearance of a small cap of scales. Those of the common Garlen White Butterfly have fifteen small longitudinal rilges, converging to the centre of the smaller extremity, the spaces between being omamentally subdivided crosswise by a series of regular grooves or chamels. It may be noticed that there is no calcareons substance contained in the shells of the eggs of insects analogons to that which forms the basis of the egg-shells of birds.

The eggs of Butterflies and Moths vary consideraljly in number, but are always abundantthe MIoth. of the Silkworm laying about 500, and the Goat-Moth above 1000. Those of Butterflies vary in similar proportions. As an instance of the heantiful symmetry with which the egrys of insects of this class are placed by the parent, in rows, close together, those of the common White Butterfly may be cited. Patches of them may often be observed upon calbage leares, when they look like small pieces of evenly woven lace, each opening being filled by a semitransparent globule, resembling a little pearl. The eggs of other kinds are disposed in many different ways, some assuming the appearance of minute bracelets of beads, round the branches to which they are attached.

The mode of exit of the young larva, or Caterpillar of the Moth or Butterfly, from the shell is very various in different kinds. In general the little creature gnaws its way out at the part nearest the head, much as a chicken at the proper time peclss at the shell till it forces its way out. The gnawing process often costs the embryo Caterpillar many hours of labour, especially when the shell is thick, as in the eggs of some species, which being laid in the autumn, are destined to resist the trials of a winter, and not be hatched till the following spring. In some cases the shell is fumished with a kind of lid, which is lifted by a very complicated pulley apparatus difficult to describe, but which the insect thoroughly understands-never making a mistake and pulling the wrong string. MIany very singular peculiarities might be enumerated concerning the mode of exit of the young Caterpillar, but I must proceed at once to describe the next stage of his career, after his escape from his little quaintly sculptured prison.

The Caterpillar or Iarva of a Butterfly or Moth differs from the larva of most other linds of insects, inasmuch as it almost always feeds on the leaves of plants, and is frequently gaily clothed in a skin of velvety texture of the richest colours, or with a mantle of silken fur of many hues, which makes it in its larra state nearly as attractive in general appearance (to those who have no prejudice against the wormlike form) as the perfect Butterly itself. The larve of most other insects, on the contrary, are either naked and repulsive-looking grubs, feeding underground, or of still more unprepossessing forms, such as those, for instance, that pass their larva state in water.

The caterpillars or larve of Butterflies, to the description of which I must confine myself, should be described here in some detail. They are most commonly furnished with six positive legs, which represent those of the future Butterfly, and cight pro-legs, as they have been termed, appendages which merely serve to balance and secure the central and posterior portion of the body of the Caterpillar while feeding, and in holding on to the under side of leares while the true legs are otherwise employed, perhaps in drawing the edge or some other portion of the leaf towards the mouth. These pro-legs entirely disappen after the Caterpillar stage, no trace of them remaining in the perfect insect. They are generally disposed as follows:-after the three 
segments next the head, which are each furnished with a pair of true legs, there are two segments without legs, the next four being each furnished with a pair of the alyove-named pro-legs; then fullow two segments without legs, succeeded by the last segment, to which is attached a final pair of pro-legse, frequently somewhat different in character to the other four pairs.

This distribution is, however, not universal among the Caterpillars of Moths and Butterfies, though nearly so among the latter. The larve of some Motlis, those called the Loopers, for instance, have the pro-legs differently disposed, and, among Butterflies, the onisciform Caterpillars of some kinds must be mentioned, which, while they have the gaily coloured slin and markings of Caterpillars, have nearly the form of the Woodlouse, to which the term cnisciform refers.

The general appearance of Caterpillars is greatly varied by the nature of the skin, and the clothing or other appendages with which it is furnished. Some are nearly smooth and glossy; others have the skin of velvety texture, others are covered with small tubercles, sumounted by a black or coloured point, sometimes maked, but from. which emerges frequently a slender filament, or a tuft, more or less spreal, of shining hairs; others are entirely covered with a thick growth of richly coloured silky fur, or exhibit it arranged in a row of dense tufts, which appears as thongh cut off square at the top. But nearly all Caterpillars that are more or less clothed with hair are those of Moths, the Caterpillars of Butterflies ( $\mathrm{a}$ an only speaking of British species) being more generally smooth, except when furnished with curions spines, such as those which distinguish the larra of the Peacock Butterfly and some others, to be spoken of in their jroper places.

The head of the Caterpillar is the only firm or horny part, being necessarily so on accomt of furnishing the levenge for the powerful jaws or mandibles, by neans of which the toughest foliage is cut through and masticated. The mouth, in the larva, or caterpillar state of insects, is very similar to that of the perfect insect, with the remarkable exception of the larve of Butterflies and Moths. In the larve of these the mouth is furmished, as before mentioned, with strong mandibles or jaws for the mastication of solid food, but in the perfect Butterfly nothing of the kind appears, the mandibles being replaced by the singular proboscis or trunk, the slender tube of which forms the only means by which the perfect Butterfly takes the little food lie requires, which consists only of the delicate juices lying deep in the nectaries of Howers. Such is the contrast between the voracity of the Caterpillar, and the delicate appetite it exhibits in its perfected form.

The eyes of Caterpillars are generally very minute, often only perceptible by the use of a microscope, and they are not always situate in or near the head. In the Caterpillars of Butterflies they are generally six in number. Their distribution is various, but they are most frequently arranged in a circle. They are nothing like the exquisite facetted eyes of the perfect insect, but are merely simple globules, and disapuear with the skin of the Caterpillar, like the pro-legs, leaving no trace in the perfect insect.

Antennæ or horns are slightly indicated in nearly all Caterpillars, in a minute rudimental state, but are often only visible by the aid of a porverful microscope.

The breathing apparatus of Caterpillars consists in a series of small apertures, termed spiracles, which are generally situated on each side of the body in a line just above the legs and pro-legs, and never occur in the head. These breathing apertures are generally surrounded by a distinctly marked iris of some bright colour, and are thus rendered tolerably conspicuous, though often very small.

The means of defeuce of Caterpillars against their several enemics is exceedingly various, but want of space prevents me from enumerating them here. I my, however, state that some have the power of spinning a web, by means of which they allow themselves to drop from a branch, and remain suspended in some less exposed place, till the danger is past. Some lrop to the 
sround, while others-the Cuterpillar of the Creat Swallow-tail Butterfy fin intance-is furnished with a fork-like appendage near the head, from which it can emit at pleasure a foctid odour, which has doubtless the virtue of proving very disagreeable to a certain class of enemies.

The enemies of Caterpillars are not only many tribes of bircls, of which they form the chice summer food, but also a class of insects, the Ichneumon tribe, who deposit their eggs beneath the skin of the Caterpillar, by means of a sharp instrument or ovipositor with which they are furnished for that purpose. The eggs of the Ichneumon are liatched by the heat of the Caterpillax's body, and the young larve of the Ichneumon feed upon the fatty substances within the devoted Caterpillar's body, taking care to avoid a vital part. When these parasitic larvie arrive at their full growth, they form their cocoons, and undergo their change to little Chrysalides within the body of their victim, which, under these circumstances, generally perishes about that period.

The growth of the Caterpillars of Butterflies is very rapid, and they cast their skin several times before arriving at their full growth, which in some instances, as in that of the common Butterfly known as the Silver-washed Fritillary, is in fourteen days.

Caterpillars are of no sex, thongh, as in the case of the eggrs of birds, a certain portion, no doubt, are so pre-organised as to become males in the perfect state, and others females.

It was not till so recently as the end of the seventeentl century that the true nature of the progress from the larva to the perfect insect was linown. At that period the invention of the microscope, combined with other causes, led to those scientific investigations which have been the means of unravelling the mystery of what seemed positive metamorphoses, but which now only appear successive steps of regular development. Swammerdam, among the foremost of a phalanx of indefatigable investigators, discovered, beneath the slin of the Caterpillar, all the embryo forms of the perfect insect, which become more and more palpable as the Caterpillar approaches its full growth. In the course of these minute dissections he discovered even the future wings, spirally folded in a singular and beantiful manner, and also the long antenus and proboscis of the Butterfly, which were closely packed against the inner front of the heal. The eventual legs, though so different in form, were also found, encased within the six pectoral legs of the Caterpillar. The skin of the Caterpillar is therefore little more than a second egg shell, and the Caterpillar, a creature become a walking egg, as it were, after having been within one that was motionless.

The strictly external members of the Caterpillar may therefore be considered in the light of a kind of disguise, and Linmeus, taking this view of the subject, gave the mame of lurre, a Latin word meaning a mask, to this stage of the development of insect life. It is indeed a very happily selected and characteristic term, by means of which the stage of insect development, which follows that of the egg, is now universally expressed.

The English term "Caterpillar" is not perhaps so ingenious and characteristic as the one invented as a scientific definition by Linnæus, but its origin is yet worth describing. In the earlier stages of the English language, cates, or cate, was a common term for provisions or delicacies of any kind, and was applied in that sense to garden herbs, or culinary vegetables : if to this we add the old Anglo-Norman verb piller, Anglicised to pill, * we obtain for the larva of the Butterfly the highly descriptive title of cate-piller, cuphonised Caterpillat, that is, plant pillagrer, or destroyer.

The chrysalis is not formed till the larva has attained its full growtl. At this period the Caterpillar, instinctively aware of the coming change, ceases to feed, quits the scene of its derastations, and seeks some spot of safety in which it may undergo its transformation, and remain securely in its semi-dormant state till the proper time for the final change, when the perfected insect is to issue from the shell of the chrysalis in all the completeness of its winged and final

* From which re have still-pillage, pilfer, \&c. 
state. Some Caterpillars secure themselves to a branch or wall liy means of a slencler web which they loop across their boclies to prevent them from falling, as they sink into the dormant state which immediately preceules their change to the chrysalis. Others suspend themselves by the tail to some convenient object by means of a knot of a similar kind of wels. These are the most usual methods alopted by the Caterpillars of Butterfices, but those of Moths often weave for themselves a perfect enclosure hy means of their silken weh, which is caller a cocoon, while others burrow in the sround, ancl construct a protective cocoon of earth, often so slight, however, that when the chrysalis is accidentally dug up by the gardener, the fragile cocoon falls to pieces, learing the naked chrysalis exposed.

After the larva of a Butterfly has suspended itself for change, the body gralually shortens and thickens, and in the course of a certain number of hours or days the soft slin of the Caterpillar shrivels, bursts, falls off, and discloses the horny case of the chrysalis, which has been so rapidly formed within.

The clirysalides of Butterflies are, as hefore stated, of much more angular form than those of Moths, having, nearly all of them, curious little spine-like points along their varions ridges; these, howerer, do not entirely conceal the form of the insect within the shell; for in almost all cases the forms of the still small wings may be observed in the space traced out loy linear markings on each sile. Undemeath, starting from the head, the form of the anteme or horns may be traced; as may also the situation of the cyes. The articulations, or joints of the aluclomen, are plainly shown, as they agree with the corresponding joints of the shell in which they are enclosed, and it is this portion of the chrysalis alone that is endlowed with any power of motion.

The colour of the clirysalides of Butterties varies from dull brown or green, to gray, and occasionally to more decided and brighter colours, often sprinkled more or less with black specks. Their most singular peculiarity, however, consists in metallic patehes, resembling gold, which some of them exhibit. This effect, which led to some curious aberrations among the elder alchymists concerning the transmutations of metals, is now well known to be produced in the following mamer. Reaumur satisfactorily explained that this golden appearance is eaused by the exist. ence of a lnyer of fluid between the transparent outer skin and the more solid part of the shell of the chrysalis, which is bright yellow, and which in certain lights produces the metallic cffect. This may be easily proved, by moving about a fresh chrysalis of the Tortoiseshell Nettle Butterfly, when it will be found that the secming specks of gold change their places with the fluid when the chrysalis is moved about in various directions. After a certain time this fluid clries, and the "gold" disappears.

The term, Clirysalis, is derived from this metallic appearnnce, which some of them exlibit;

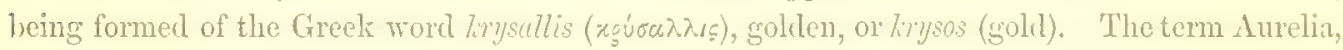
likewise, by which this stage of insect development is also known, hear's a similar import, from the Latin words aurum (gold), or aure (goliten). This last was a term in more common use than chrysalis among our early Linglish collectors, who were thence temed Aurelians.

The time that the Butterfly remains in the chrysalis state raries in different species. But it may le stated that the chrysalides of the early broods of Caterpillars generally remain in the chrysalis state from fourteen to twenty days, while the late hrovits, even of the same kinds, generally continue in the chrysalis throughout the winter, and the perfected insect loes not emerge till the following spring or summer.

When the time is arrived for the insect to escape from the horny husk or shell, the time of the coming change may be recognised in the chrysalintes of Butterties by the gradual darkening of the shell and its incruasing transurency, by means of which the rich colouring of the wings within may often be perecived, and the species of Butterfly alout to emerge casily distinguisherl. 'The first synutom of the positive Treaking ont of prison is shom by the splitting wy the back of the shell of the chrysalis, cansed by the muscular efforts of the insect within. The escape is 
then rapidly effected, but the wings are as soft as wet paper, and not larger than the indications of their outline upon the shell. They attain their full size, however, very rapidly, often within an hour, and sometimes in half that time, while in other cases a whole day is required. As the wings thus rapidly grow, or dilate, they harden at the same time, and, under the influence of a fine sunny day, the insect has only to raise and drop these splendict new additions to his organisation a few times, before he feels their strength sufticient for their destimed purpose, and boldly takes to the new exercise of flight, in which he proves himself at once an adept without any previous practice.

Having now traced the Butterfly from the egg to the perfect or imago state, it remains to state, in as fer words as possible, the nature of the scientific tems by which his stages of development have been distinguished, and by which the order to which he belongs is defined.

The egg state, as we have seen, was succeded hy the Caterpillar stage, - that for which Linneus invented the generic term laru, or masked state. This was again succeeded by the chrysalis, for which the same celebrated naturalist invented the alnost equally felicitous term purpe, being the Latin term for an infant, which, bound in its swadlling clothes, after the ancient fashion still prevalent on the Continent, suggested to Limnous the idea of the larva bound in the chrysaline shell during the period which immediately preceded its change to the perfect state. This last he termed the imago state, or that of the true image, which hal only been as it were, foresharlowed in the previous stages of its existence. The aptness of these definitions is proved hy their general aloption-no other terms than larra, pupa, and imago, being now employed in scientific works to designate the three principal stages of insect life.

In dividing the vast mumbers of the insect tribes into separate and homogeneous 'orders,' ench distinguished by a title of appropriate character, the great fanily of Moths and Butterflies were formed by Linneus into an 'order' bearing the title of Lemiloptere, a term formed of the Greek words lcpis, a scale, making lepilos in the plural, and ptcron, a wing, in allusion to the scales, with which the wings of this class of insects are invarialuly clotled. Aldrovandus, one of the old Italian naturalists, a contemporary of Shakespeare, aclopted a similar mode of classification in reference to this orter of insects, calling them Alee ferinose, that is, the farinaceons, or flourywinger order. This is, however, less strictly clescriptive than that of Linnæus. But then Aldrovandus wrote before the invention of the microscope, which enabled later naturalists to define more exactly the nature of the seeming powler which covers the wings of Butterflies. A more recent naturalist, differing from Limmens, regardecl the proboscis, or trunk, as strictly peculiar to this order of insects, and thence called them the Glossutu, or tongued tribe, a term founded on the Greek name of that organ. The Limnan term has, however, prevailed; and Butterflies and Moths are now finally only lnown in scientific classification by the term Lepidoptera.

Having settled the principle upon which the order was to be established, and the name by which it was to be distinguished, Linneus next attempted a series of subdivisions. Of these he made three principal ones. The first he termed Pupilio, from the ancient Latin name by which the Butterfly was popularly known. This clivision included all the Butterflies, or day-flyers. The second he fancifully termed Sphinx-a name which he adopted, because the Caterpillars, when in repose, assumed an attitude not unlike that in which the fabled Sphinx is generally represented. This division included the first section of the great Moth family-- being those which generally fly by twilight. To the third class, consisting of all the rest of the Moth tribe which generally fly by night, he gave the term Phulene, a term which he may have adopted

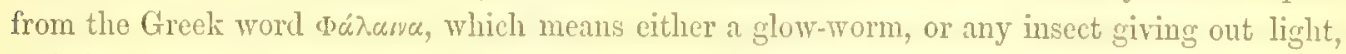
and thus rendered conspicuous by night - the moth being only noticed in flight at that time: or he may have arlopted another meaning of the word, which refers to such insects as fly towards a lighted candle. Latreille found the general division thus effected npen to little oljection ; hut 
he discarded the fanciful terms by which they were distinguished, and adopted the more descriptive term Dimma, or day-1lyers, for the first section; Cremescularie, or twilight-flyers, for the second division; and Noume, comprising the night-flyers, for the last. The more recent method, however, adopted by Dr. Boiscluval, in which only two great sululivisions are recognised instead of three, has been generally adopted in the scientific world. The great order Lepidontere is, therefore, now divided, first into Rhopuloccer, or those having clubbed horns, or antennæ,

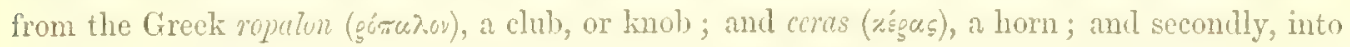
IIcterocera, consisting of such as have rarious linds of antenne, but never clubbed-the last term being composed of the Greck words cteros (rrgos), dissimilar, with the addition of corus, a hom, as before.

These scientific terms, Rhopaloceve and IIeteroceru, correspond very naturally and conveniently with our popular terms, Butterflies and Moths, and serve to separate the great scalewinged family in a precisely similar manner.

It is only with the first division, Phopatocera, or Buttertlies, that we have to do in this volume: and of these, only with that small section which are natives of the British Isles, among which, however, will be found some remarkably beautiful species, and much to interest the student in tracing their metamorphoses, their habits, their distribution, and their classification.

With "Part Ten" of this work some account will be given of the best mode of capturing Butterflies; also of rearing them from the egg or Caterpillar stages. It will also be shomn in a detailed account of some portions of the plyssiology of insects, that the power of appreciating pain is almost entirely absent in their organisation; and that, therefore, Fntomological pursuits are entirely free from the charge of crutely which has been so often and so ignorantly urged against them. 



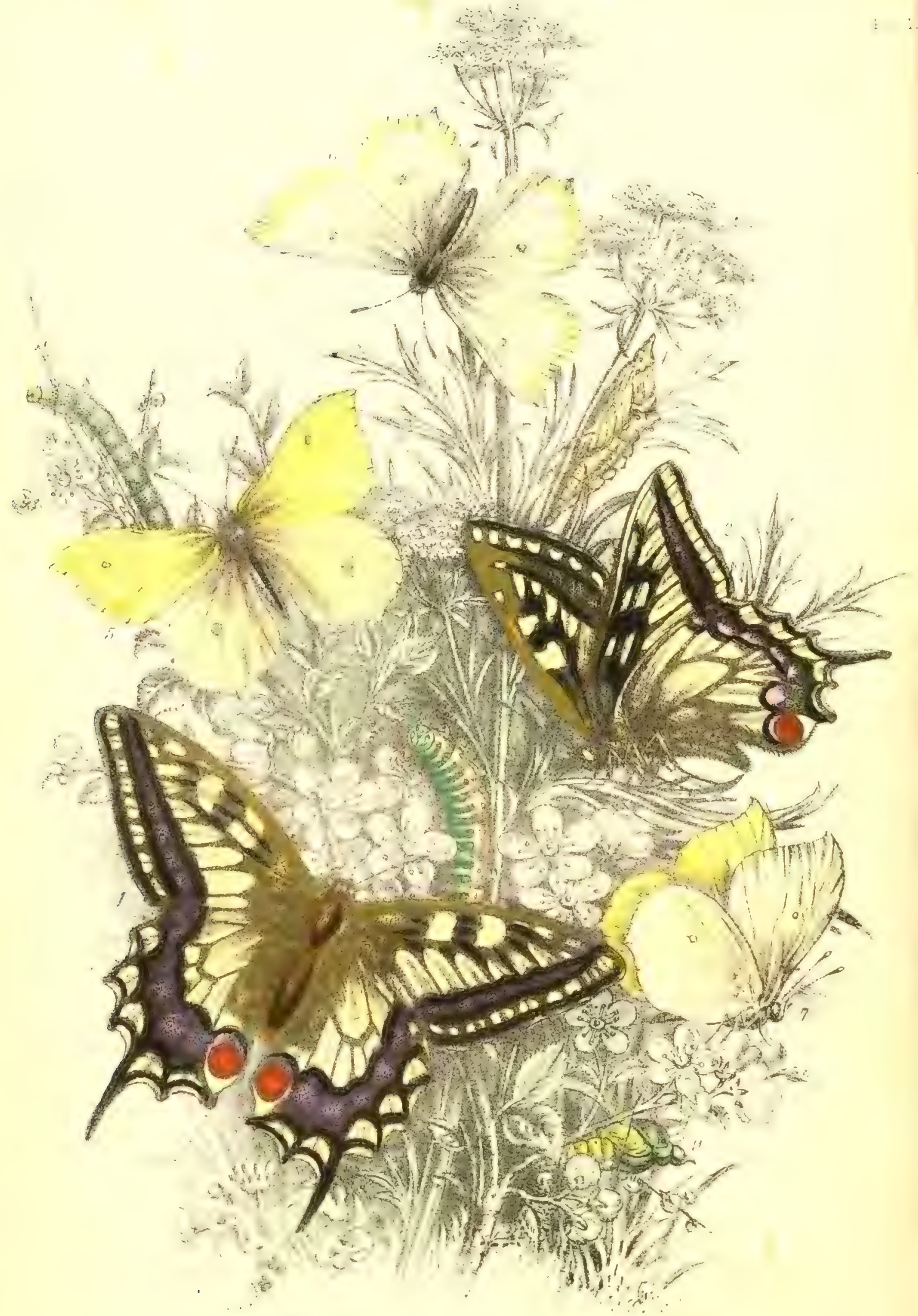




\section{THE GENERA AND SPEUIES}

\section{OF' \\ B R I T IS H B UT T E R T L I ES.}

\section{PLATE T.}

No. 1.-The Great Swallow-tailed Butterfly (Papilio Machaon).

No. 2.-The Under side of the Great Strallow-tailed Butterfly.

No. 3.-Tho Caterpiliar of the Great Strallow-tailed Butterfly.

No.4.-The Chrysalis of the Great Sraliom-tailed Butterfly.
No.5.-The Brimstone Buttertly (Gonepteryx Rhamni).

No. 6. The Female of the Brimstone Butterfiy.

No.7.-The Under side of the Male Brimstone Butterfly.

No. 8. - The Caterpillar of the Brimstone Butterfy. No. 9.-The Chrysalis of the Brimstone Butterfly.

THe division Rhopalocere, as shown in the Introduction, is that section of the order Lepidopsterc containing all the groups distinguished by clubbed antenna, that is, all kinds of "Butterflies ;' which are thus distinguished from Moths.

The first Fomily of this division are terned the Papilionide.

The first Sub-Family, according to the system I am following, is defined as Papilionidi, containing only one British genus, Papitio, a genus which includes but a single native species, though the exotic kinds are so numerous, and so various, both in form and colour.

The insects comprised in the genus $P$ (pilio are distinguished by antenne somewhat elongate, and terminated by a knob or club of moderate size. The palpi are very short, and have the third joint almost obsolete; the eyes are large, and not clothed with hairs, as in some other genera. The abdomen is short, and the hind wings are long and narrow, and generally terminate at the angle next the body in a more or less elongated portion, having a tail-like appearnec. The anterior pair of legs are alike in both sexes, and are fitted for walling, as well as the two hinder pair, which is not the case in genera which I shall shortly lave to describe. The Cater-

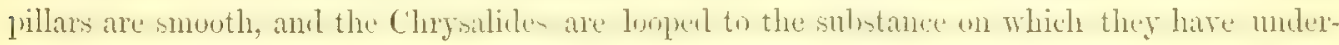
gone their transfomation with a thead of web: they are also attached by the tail, the heal pointing upwards.

Papilio Muchaon (the Great Swallow-tail, No. 1), is the largest, and perhaps on the whole the most strikingly handsome of all our native Butterflec, and is abmilut in mimy localitie. It is, however, rare in the metropolitan counties, though there are records of its occasional capture in Hampshire, Sussex, Kent, and even Middlesex. It energes from the chrysalis in May, and is seen till the end of August, but must be sought in its own farourite localities, the Fens of Inntington anl Cambridgwhire, or at Whittlera. Were, which is another of its haunts.

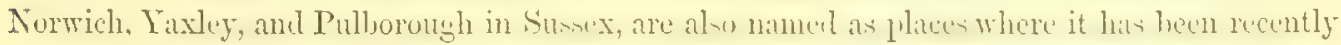
captured in some plenty. The Caterpiline (No. 3) is fonnd in June and Selptemler', there being two broods according to Continental entonulogist:. It fecels unon nuany plants conmon to 


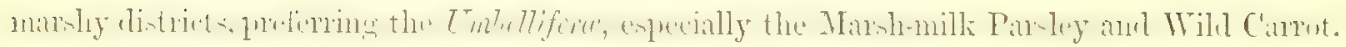
It is furnished with a fork-like appendage near the head, by means of which it is said that it is aljle to emit a fatid odour which keeps off Ichemmons. The under side of the wings of this fine insect is much paler than the upper, and somewhat differently marked, as represented at No. 2. The chrysalis of the Great Swallow-tail (No. 3) is shown suspended to a branch of the Wild Carrot. P. Ifuchoon is much more alundant on the Continent than in England.

l'opilio Podalivius was formerly claimed as a British species, and it is to be regretted that the proofs have turmed out insufficient, and that it camot even be artificially naturalised after several attempts, though very common on the neighlouring shores of the Continent, for it is as fine an insect as $P$. MTacheon, with the markings of which its broad zelna-like stripes form a fine contrast. This handsome species is exceedingly common in the Campagna, in the immediate neighbourhood of Rome, where I captured many fine specimens, and from whence I brought clirysalides which I reared in England, turning many of the perfected insects loose in suitaljle localities, in the hopes that the species might establish itself; 1but they all disappeared withont any results. Both P. Muchuon and P. Polutivius are, as I have said, common on the Continent, and they are anong the species named by Linneus, who in conferring specific and sometimes even generic denominations, seldom adopted descriptive or characteristic names in the way now generally alopted, hut gave arbitrary appeliations, after historical or mythological persons of the early ages of Greece or Rome. These two fine species received their names in this manner after the two sons of Esculapius-Podalirius and Machan, and will continue to bear them, in honour of their great name-father, so long as the present systems of science shall continue, though so completely at variance with the present system of momenelature.

The second Sub-Family of the Pupitionide is that of the Rhodoceridi, a name derived from. Greek words meaning red-horned, in allusion to the pinkish or brownish pink antenne by which the genera it contains are distinguished: these are the following, Concptoryn and Colids.

The genus Goneptryy is so named from the angular form of the anterior wings, from the

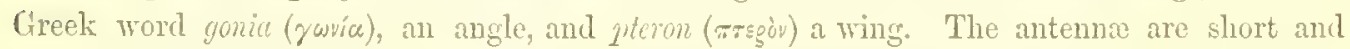
rather robust, terminating in a club, towards which they gradually thicken. The front pair of legs are alike in both sexes, and are, as well as the posterior pairs, fitted for walking. The Caterpillars are attenuated at each end, and the Chrysalis always attached by the tail, as well as suspended by a loop round the middle.

Gonepteryx Rhami (the Brimstone, No.5), is generally the first of the Butterfly tribe to announce the coming summer, making his appearance, on fine days, as early as March or even February; becoming, however, much more abundant in the more genial days of April. The female (No. G) is nearly white, and by the inexperienced is often taken for one of the common Garden Whites. The under side of this insect scarcely raries from the upper, but in the male it is somewhat paler, as shown at No. 7. 1 second brood appears in August.

The Caterpillar (No. 8) feeds upon the leaves of the common Buckthorn, Ihommus Cuthorticus, from which its specific name is derived, and also upon the Berry-bearing Alder, Ir. Frungulus, and some other allied trees. The Clirysalis (No. 9) is green, with some small red dots, and suspended with a loop like others of the family.

This pretty insect is common in all parts of England, as far north as Newcastle, lunt is rarely found in Scothand. A beautiful variety oceur's commonly on the Continent, once made a separate species as Gonepteryx Cleopetru, in which the antexior wings of the male are beautifully suffused in the centre with a lirge patch of the richest orange colour, becoming fainter towards the edges. Some specimens occasionally captured in England are mentioned as having slight indications of this peculiarity. In the neighbourhood of Rome, however, I captured numbers of the orange raricty, which appeared to be quite as common there as those of the sulphur coloux. 



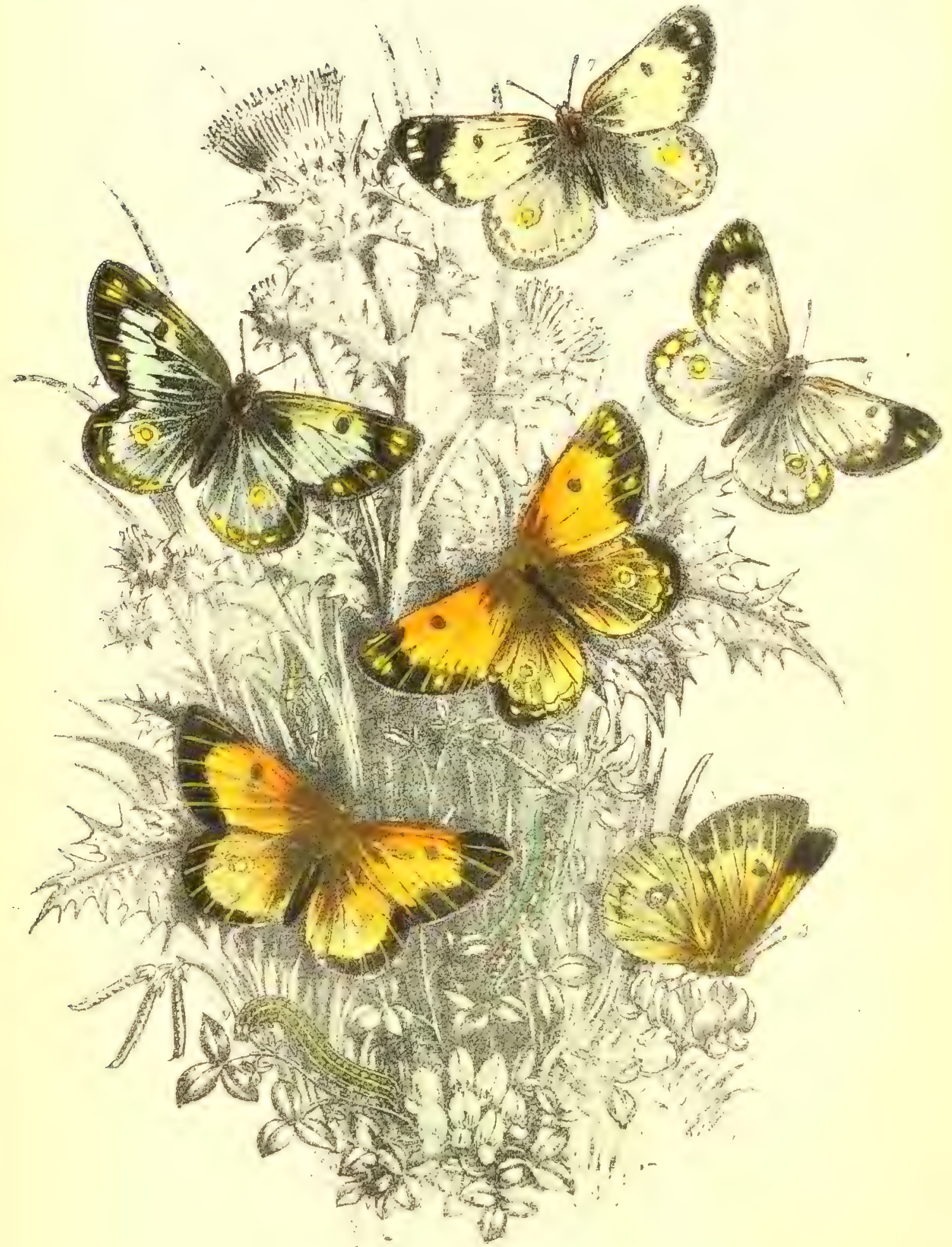




\section{PLATE II.}

No. 1.-The Clouded Yellow Butterfly (Colias Edusa). No. 2.-The Female of the Clouded Yellow ButterAly.

No.3.-The Under side of the Clouded Yellow Butterly.

No. 4. $-\Lambda$ rariety of the Clouded Yellow Butterily.

No. 5. The Caterpillar of the Clouded Yellow Butterfly.
No. 6.-Tho Chrysalis of the Clonded Ycllow Buttcy"fly.

No. 7.-The Pale Clouded Yellow Butterly (Colias Iyale).

No.8.-The Female of the Palo Clouded Tellow Butterlly,

No. 9.-The Caterpillar of the Pale Clouded Yellow Butterfly.

THE Genus Colias. The insects contained in this genus are more robust, both in the texture of the wings and the dimensions of the body, than the preceding, from which they are also distinguished by the rounded apex of the anterior wings, the deep black bordering of which forms another distinctive feature. The antennæ are short, rather thick, and swelling gradually into the final club or knob. The Caterpillar is naked, somewhat elongate, and tubercled. The Chrysalis is rather short, and at the head somewhat hooked in a beak-like form; it is suspended by a girth of web, and attached at the tail by a knob of the same substance. The name Was conferred by Fabricius, who, in this instance, following the system of Linnæus, gave an arbitrary one, a surname of Aphrodite, the Greek Venus, who had a statue on the Attic promontory of Colias.

- Colias Edusa (the Clouded Yellow, No. 1), is one of our handsomest Butterflies, the fine contrast of its black and orange markings having probably suggested to Fabricius the idea of selecting one of the titles of the goddess of beanty as the name of the genus. It is very common in some seasons in this country, but in others comparatively rare. Its abundance once in three or four years has not been satisfactorily explained. The Caterpillar (No. 5), is found in the spring feeding on different plants of the trefoil family, and the perfect insect appears later in August, frequenting lucern and clover fields, and is sometimes seen as late as October, at which time the sunny side of railway banks is said to be one of its favourite resorts. Bembridge, Isle of Wight, Blandford, Brighton, Plymouth, Teignmouth, Winchester, \&c., are named as good localities for the capture of this handsome insect.

The female (No. 2) is generally rather larger than the male; is of a somewhat clearer orange, and is also distinguished by bright yellow dashes in the black border. The under side of the male (No. 3) is almost exactly similar to that of the female, though so different on the uper sile, both being remarkable for the spot of silver in the centre of the circlet in the hind wings.

No. 4 is a striking variety of the female, of not uncommon occurrence, in which the whole of the orange and yellow tones are suffused with a pervaring tone of hluinh gray, which grive rather a green tone to the hind wings. The chrysalis is represented in No. 6.

Colias Hyale (the Pale Clouded Yellow, No. 7), is a very distinct species, and much more rare than C.Edusc. Its wings are of very chaste and delicate colouring, which may have suggested to Limneus its specific designation of Hyale, one of the nymphs of Diana, for it figures under that name in lis great division Popilio. The perrating colour of the male is a 
delicate lemon yellow. It does not differ in its markings from the female (No. 8), lout the ground colour of the latter is creamy white. On the under side, however, they are both alike, and though so much more delicately coloured than C. Edusu on the mper surface, they are on the under side much more strongly tinter than that insect, though the tones are similar.

The Caterpillar (No.9) feeds on Medicago and other leguminous plants in the spring, and the perfect insect appears in the autumn. Though a very common insect in the neighbouring countries of the Continent, it is comparatively rare in England, except in certain seasons; in 1842, for instance, it was abundant, and it has becn taken in some numbers during the present season. The following are the places in which it has been captured most frequently: Brighton,

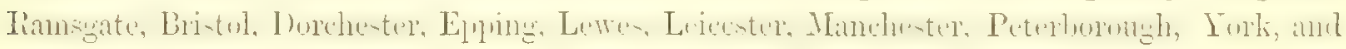
some places in Ireland.

I am indelsted to my friend, MIr. ADA WHITE, of the British Museum, for the following note:

"The two British species of Colius are very widely distributed. The $C$. Hyale has been taken in the Punjaub, and also on the slopes of the Himalaya, while both the species are found at Dhargeeling in N. India, and at Shanghai, in Northern China. Indeed there seems to be cvery reason to believe that botlk the species', like the 'Painted Lady Butterfly', are all but cosmopolitan. The question, how some species are so generally distuibuted, and others so limited in their geographical range, is one of great interest. We may yet also be able to ascertain why some species are abundant every five or six years, like the species of Colue, and again become scarce. The moisture or dryness of the atmosphere, and the conseqnence of such meteorological changes, must affect all insects more or less, but some more particularly than others. A long period of frost kills many, and might kill all, of the specimens of certain shell-fish in our seas, as has been well observed by the late Hugr MIrLer, while others, closely allied, are quite unaffected. These others are found to extend far north, into regions subject to long periods of frost; while the clelicate species belong specifically to temperate, or more southernly regions. From somewhat similar reasons, Colias Edusa, and Hyale, and the 'Camberwell Beanty' Butterfly ( $F^{\top}$ unessa Antiopu), may vary in their abundance. Other species of Colius are found very far north. The sobered gaiety of the Colias Boothii, of Curtis, cheered Sir James Clarke Ross and his comrades on the shores of Prince Regent's Inlet; while Sir John Richardson, Captain Collinson, and other Arctic voyagers, sent to the British Museum species of Colias, and other Butterfies, from localities where an Arctic winter mles for nearly threequarters of the year. Where flowers bloom on the disappearance of the snow, there Bees and Butterflies are found, and none are more cheerful or gay than the species of Colius. At St.

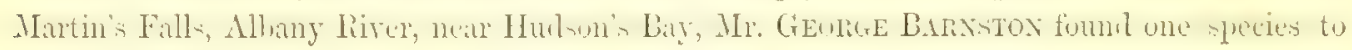
be very common." 


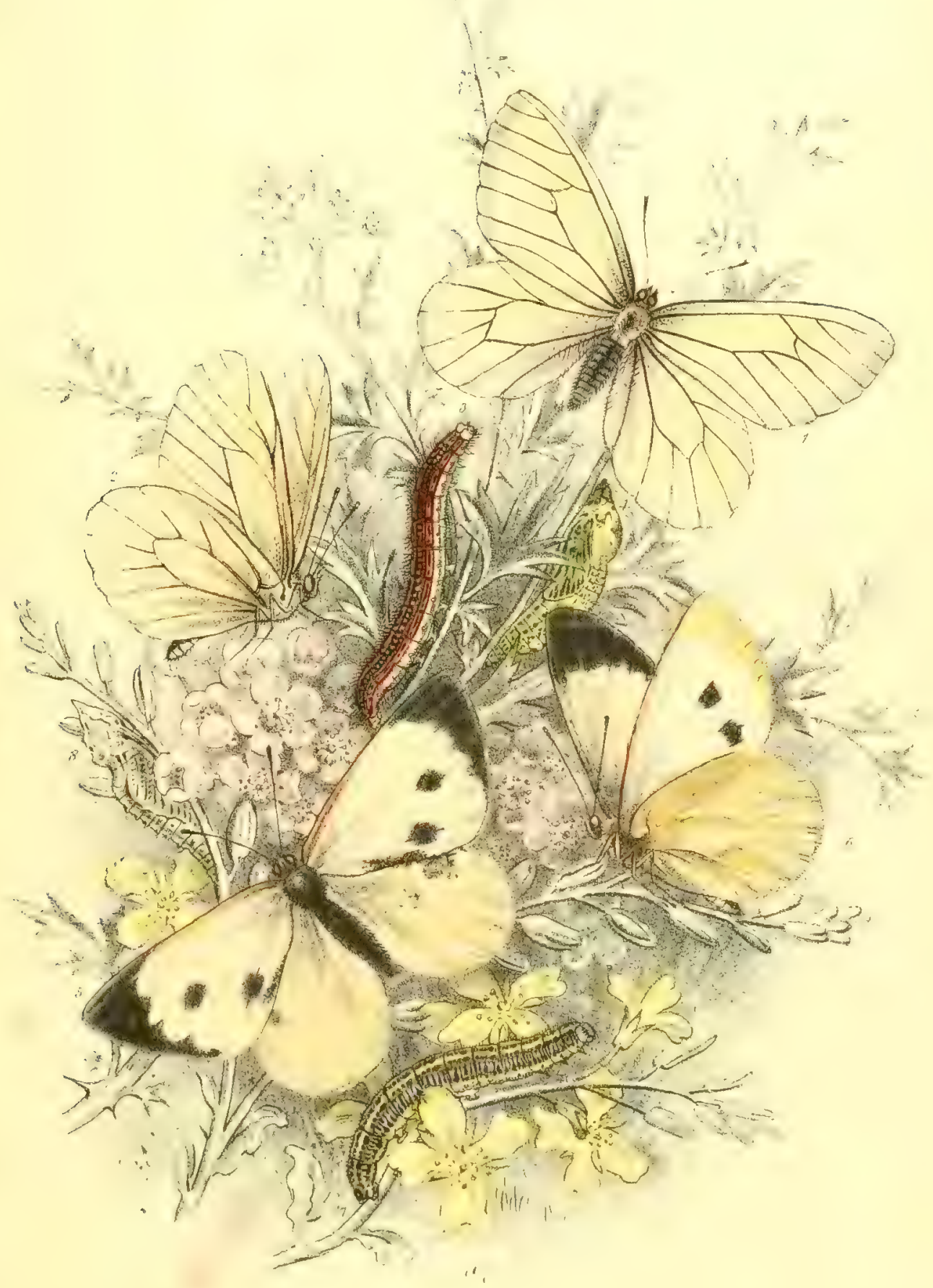





\section{PIATE III.}

No. 1.-The Black-reined White Butterfly (Aporia Cratagi).

No. 2.-The Female of the Black-reinerl Thite Butterfly, showing the Under side.

No. 3.- The Caterpiliar of the Black-reined Wlite Butterfly.

No.4.-The Chrssalis of the Black-reined White Butterily.
No. 5.-The Great Cabbage-Thite Butterfy-the Female, (Pieris Brassice).

No.6.-The Male of the Great Cabbage-Thite Butterfly, showing the Under side.

No. 7. - The Caterpillar of the Great Cabbage- Thite Butterlly.

No. 8. The Clrysalis of the Great Cabbage-Thito Butterfy.

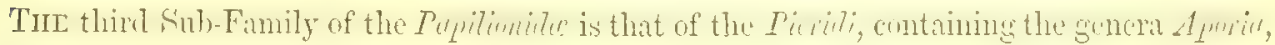
Pieris, Euchloe, and Leucophasia.

The gents Aporiu contains but one British species, resembling, in general aspect, the Garden Whites of the genus Picris, but distinguished from them in a very marked degree, both by its habits and structure. In this genus the first distinguishing character appears to be the excessively thin layer of scales by which the wings are covered, which are nearly transparent. It is, doubtless, from this circumstance that Huibner adopted for it the generic name Aporia-a Greek word, meaning destitute, in allusion to the nakedness of the wings. The second, is the robust structure of the veins or neurations, which are very conspicuous by their black or brown colour; and in some species, especially the British one, $A$. Cratari, a similar nervure to those which branch orer and support the broad surface of the wing, also extends round the extreme edge, which is without the usual cilia or fringing. The legs are similar to those of the preceding subfamily, but the antennæ are longer, and the club, though graduated in a similar manuer, is not so large. The larva is of long proportion, and partially clothed with short hairs. The chrysalis

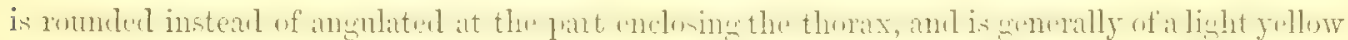
or green colour, marbled with black, and is suspended by a girth of web, and attached at the tail.

Aporia Cratagi (the Black-reined White, No. 1). This conspicuous insect is one of those which may be called periodical, as it is extremely rare except at intervals of three or four years, or more, when it appears in great abundance. On the Continent it is generally plentiful, and its larva are very destructive. Linnæus called this species the pest of gardens, and Kollar and De Geer have given a detailed account of it as one of the insects most injurious to the prospects of more than one class of cultivators. It has been occasionally seen on the wing in such vast abundance in the north of Europe as to produce the appearance of a widely prevailing snow-storm.

The female (No.2) is represented so as to show that the under side of the wings is the same as the upper, and, at the same time, to exhibit the distinctive colour of the veins or neurntions,

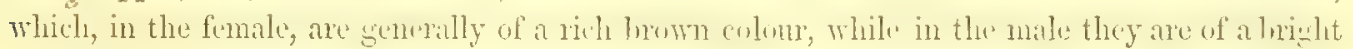
shining black.

The Caterpillar (No. 3) feeds on the Whitethorn, Crategus Oxyacantha, and other kinds of

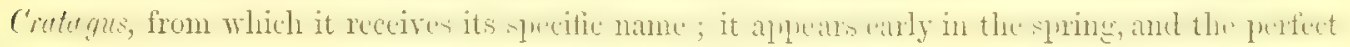
insect in June.

The Chrysalis is represented under figure 4.

The most recent places noted for the capture of this Butterfly are Corsham in Wiltshire, 
Lyndhurst, where it was abundant, Peterborough, Herne Bay, some places in the Isle of Thanet, Moreton in Deronshire. The New Forest is also mentioned as one of the places where it was formerly taken in abundance, as well as Chelsea, Muswell Hill, and other localities near London.

The genus Pieris embraces all those white Butterties of our garlens, popularly known as the "Garden Whites." The name Pieris was conferrecl by Schrank, in sulbstitution for that of Pontiu, which it was desimble on several accounts to change. In selecting the new term, now generally acepted, the Geman naturalist may have been influenced by the consideration it was probably the observation of the metamorphoses of some of these abundant species (the types of the grenus) that suggested to the poets of Greece the loeantiful faljle of Psyche, that is, the Soul, founded on the apparent death of the creping Caterpillar in its chrysaline condition, and its seeming resurrection in a more perfect state. If so, the term Pieris, from the Greek Pieriles (mrsioss), the Muses, seems a very appropriate one, of that funciful link adopted by Limnaus; but now very rarely, if ever, alopted in the formation of either generic or specific nomenclature. The genus Pieris is listinguished by larger and more slender anteme thm the preceling; the wings are ratler pointed, and tipped with black; and the females are distinguished hy one or more black spots near the centre of the anterior wings, which are always alsent in the males; and all the wings are edged with a deeper and more regular fringe than any of the preceding genera. The palpi have the terminal joint as long or longer than the second, and the legs are long and slender, and alike in both sexes; the anterior pril being perfect. The Caterpillars are tuberculated, with short hairs springing from the tubercles. The chrysalis is remarkably angulated, especially above the thorax, where it is rounded in the preceding grenus. It undergoes the change in various positions, Jut always looped, and attached by the tail.

Pieris Brassice (the Great Cabbage White, No. 5), is by far the largest of the genus, and is a very handsome insect, well worthy of more careful examination than it generally meets with; for it is not merely black and white, as appears at a first glance, but chastely decorated with many beautiful gralations of colour. The ground tone of creany white, for instance, deepens towards the front of the anterior wings, and the hind ones are entirely of a warmer hne, both being enriched liy a soft dusky shade at the base, formed of inmumerable gray specks, while the black tip is softened off into the delicate ground colour in a similar manner. On the underside, as shown in the representation ( $\mathrm{No}_{0}$ 6), the tips are buff where they are black above, and the hind wings are entirely buff, microscopically powdered with minute black specks, and ornamented with a slender line of orange down the anterior margin; both wings liaving the under side of the fringe of a warmer buff than that of any other part. The antenne, also, are ormamented with a beautiful series of dots beneath, which are not risible on the upper side. The female (No.5) exhibits conspicuously the black dots by which the anterior wings of that sex are distinguished, and is generally, as in many species of Butterflies, rather larger than the male. The male, thongh without the black spots on the upper surface, exhibits them conspicuously on the underside of the anterior wings.

The well-known Caterpillar (No. 7), of which two broods appear every season, appears to prefer the common garden Cabbage to all other food, though it is often found devouring many kinds of Cruciferous plants. The Chrysalis (No. 8) is represented attached, in the way which characterises this and other allied genera, to a stem of Cablage, in flower, though it generally prefers the trunk of a tree, a wall, or old paling.

This well-known species is common everywhere, not only in England, but in the whole of Europe, the north of Africa, Asiatic Siberia, and even in Nepanl and Japan, though the species found in the two last-named places are thought by some to present sufficient distinction in some features to cause them to be erentually classed as distinet species. 



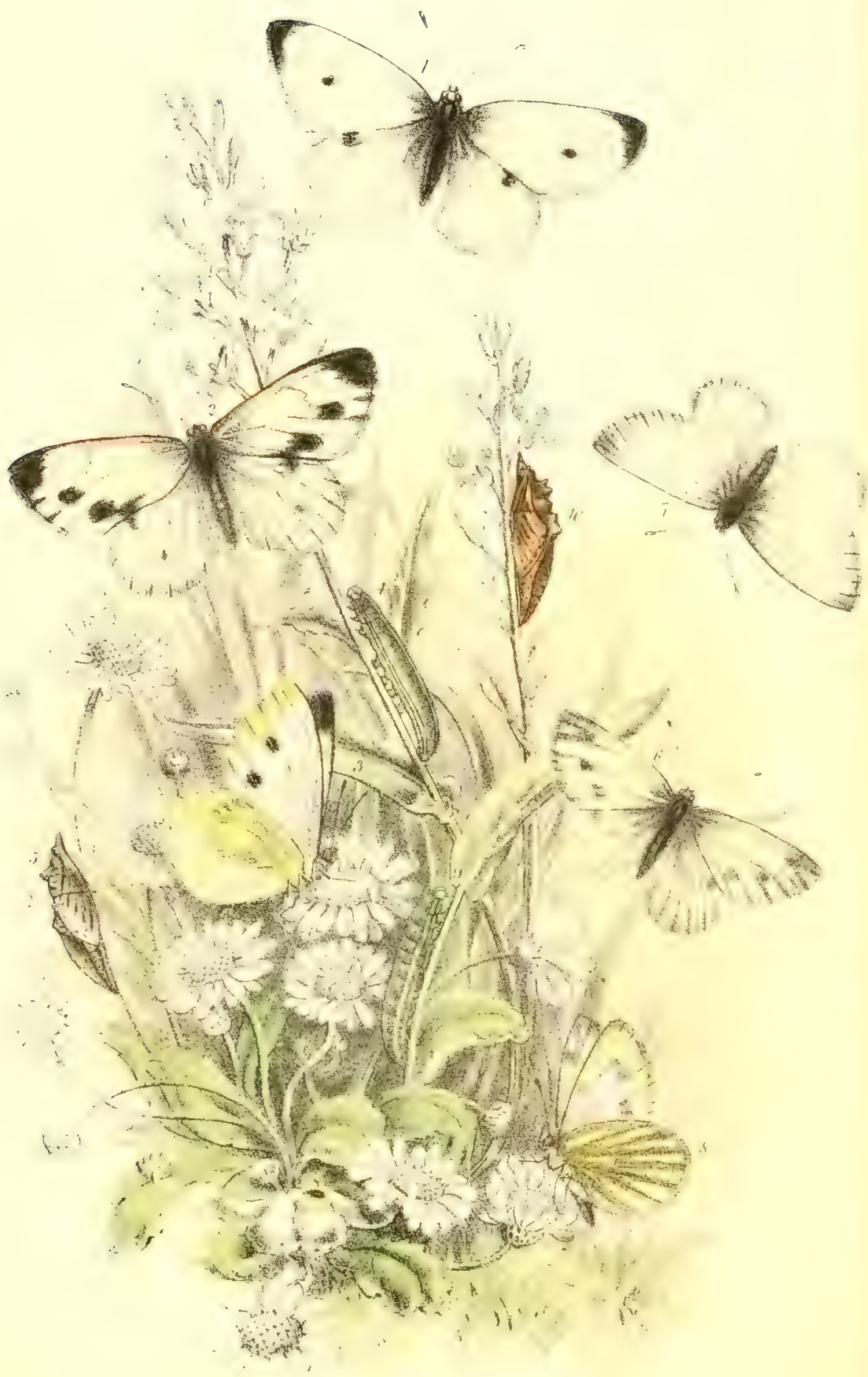




\section{PLATE IV.}

No.1.-The Small Cabbage-White Butterfly (Pieris Rapue).

No. 2.-The Female of the Small Cabbage-White Butterfly.

No. 3.-The Under sicle of the Small Cabbage. Whito Butterly.

No. 4.-The Caterpillar of the Small Cabbage-Thito Butterfiy.

No 5.-The Chrysalis of the Small Cabbage- White Butterify.
No. 6.-The Green-reined Whito Butterlly (Pieris Napi).

No. 7.-The Female of the Green-reined White Butterily.

No. 8.-Under side of the Gren-roined White Butterfly.

No. 9. -The Caterpillar of the Green-reined Thito Butterfly.

No. 10.-The Chrysalis of the Green-reined Whito Butterily).

Pieris Rape (the small Cabbage-White, Nos. 1 to 5) is frequently mistaken by thoso unlearned in the natural history of Butterflies for the young of the larger species, $P$. Bressice; and at the first glance there appears a great similarity between them. On a closer examination, Iowever, it will be observed that there are several distinguishing characteristics, altogether independent of size. In the first place, the males lave generally a more or less distinct black spot in the centre of the fore wings, which is never found in the larger lind, while the two black spots of the female, (No.2), are more conspicuous, and in that sex the wings, on the upper surface, are often thickly powdered with gray, so as to give them a much more dusky appearance. The underside (shown at No. 3) exhibits the hind wings of a darker buff, and much more thickly powdered with brown than in the large lind. I lave seen specimens with the buff of the underside of the hind wings very much darker than in the specimen represented at No. 3, and others with a strong shade of dusky green running up the veins or nervures; the specimens of the last-named lind being, I believe, liybrids between $P$. Repe and I. Nipi. The Caterpillar, (No.4) appears both in the spring and autum, there being two broods annually. The chrysalis, (No. 5) is found attached to branches or some other support, in a similar manner to that of the larger species, and if produced in the autumn it remains in the pupa state throughout the winter, the perfect insect appenring early in the spring. The chrysalides resulting from the spring brood of Caterpillars only remain in that state from eight to sixteen days before the perfect insect is produced.

The most marked distinction to be found between this and the larger species is, however, to be sought in the preparatory or Caterpillar stage, in which it is perfectly distinct, as will be seen on reference to the representation No. 4, Plate IV., as compared with No. 3, Plate III. The Caterpillar of $P$. Rupce feeds on several kinds of cruciferous plants, especially the common Rape, from which its specific name is derived; and also the wild Mignonette, and many exotic

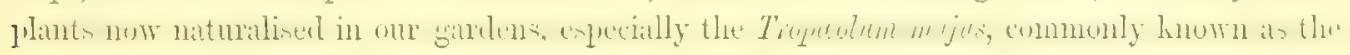
Nasturtium.

This species varies rery remarkally in its making, some of the males being entirely without the white spot in the centre of the fore wings, while otler's are fomm in which the whole of the uper surface of the wings are of a chisly sray ; and there are many intermediate varicties. 


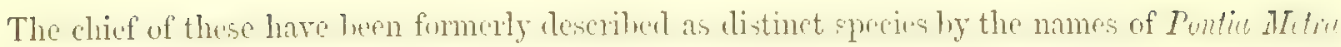
(distinguished by its smaller size), Papilio alba media immaculata (the male of $P$. Raper), Papilio albe matic trimaculute (the female of $P$. Riepee), and several others.

Picris Nopi (the Green-veined Cabbage-White, Nos. 6 to 10) has also been confused both with $P$. Brassice and the species last described, by those unacquainted with entomology; it is however very distinct from both. From $P$. Pupce by the almost constant absence of the black spot in the centre of the fore wings of the male, and from both by the peculiar green markings of the under side of the hind wings, from which it takes its popular name, the Green-veined White. The male (No. G) is not only without the black spot above alluded to, but also nearly without the dark marks at the tips of the fore wings, though they are sometimes much more conspicuous than in the specimen represented. The female (No.7) has the spots, and the marks at the tips of the fore wings similar to those of the female of $P$. Rape, but generally much paler. The Caterpillar is distinguished from that of the preceding species by the absence of the yellow line down the back. It feeds upon Brussica nom, from which it takes its name, and also upon several other cruciferous plants, especially the common calbage; in feeding upon which, both this and the preceding species do not confine themselves to the external leaves of the plant, like the larve of $P$. Brassice, but eat into the heart; they are consequently much more destructive, and are known in France as the ver du cour. The Caterpillars appear in spring and antumn, like those of $P$. Ihupe. Both the small species of Picris are further distinguished from the large one by the disposition of the eggs, which are laid singly, instead of in agglutinated patclies.

The varieties of $P . N^{\prime}(p)$ are numerous, among the most remarkable of which are those specimens which have the veins of the upper side of the wings rather strongly marked with dusky black, which were made a species by H. Sterurens, under the name of $P$. Subllice; and the $P$. Napece, made a separate species by Esper, which is of a larger size than the ordinary specimens of $P$. Nipit. 


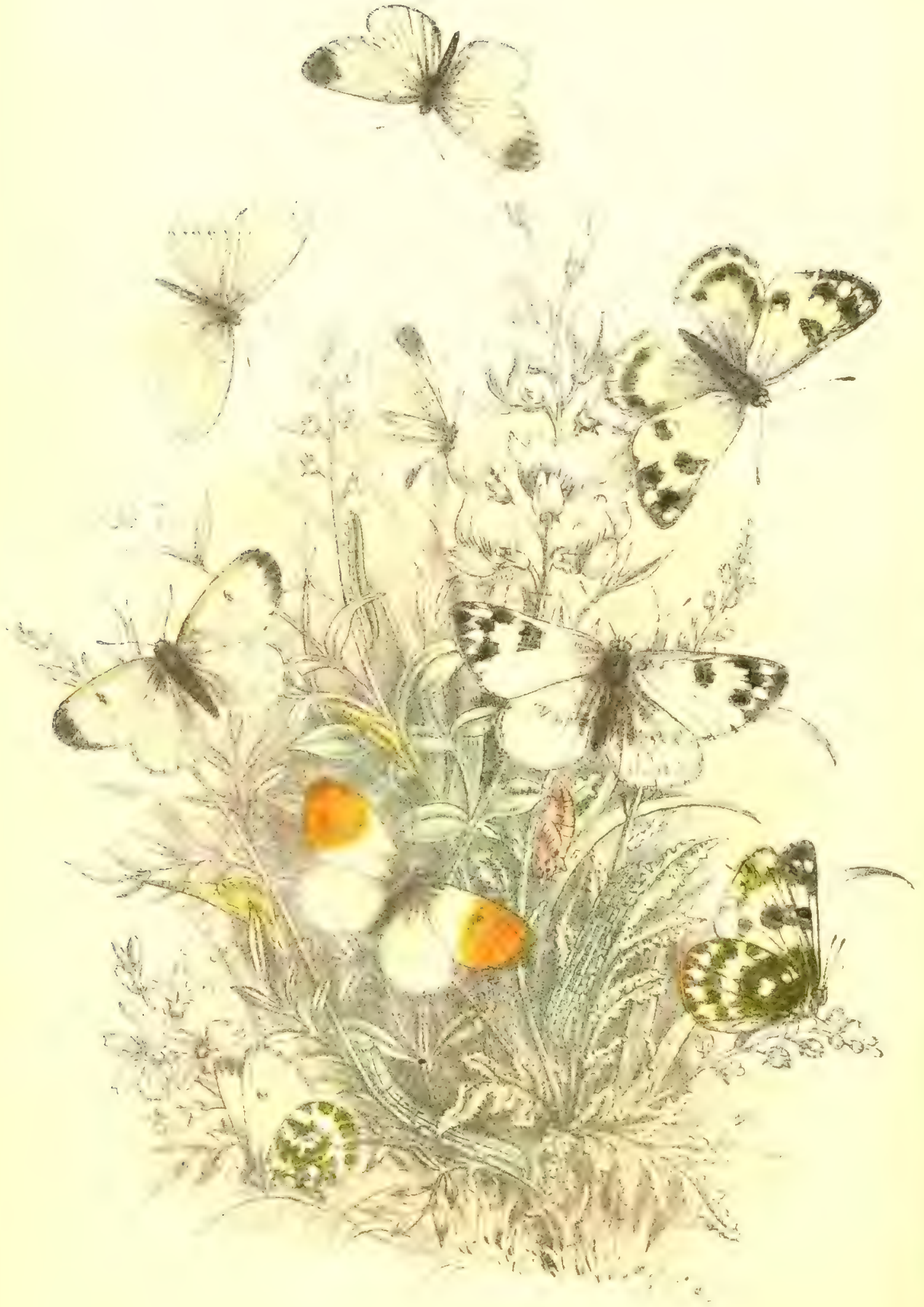




\section{PLATE $V$.}

No. 1.-The Green-chequered Thito Butterdy (Pieris Daplidice).

No. 2,-The Female of tho Gren-chequered White Butterly.

No. 3.-The Under side of the Green-chequercd White Butterfly.

No.4,-The Caterpillar of tho Grecn-chequered TVhite Butterfly.

No.5.-The Chrysalis of the Green-chequercd White Butterfly.

No.6.-The Orange-tip Butterfly (Euchloe Cardamines).

No. 7. - The Female of the Orange-tip Butterfly.
No. 8. - The Under side of tho Orange-tip Butterfly. No. 9.-The Caterpillar of the Orange-tip Butterfy. No. 10.-The Clurgsalis of the Orange-tip Butterfy.

No.11. The Wood White Butterfly (Leucophasia Sinapis).

No. 12.-The Female of tho Wood White Butterfly. No. 13.-The Under side of the Wrood White Butterfly.

No. 11-The Caterpillar of the Wood White But. terfly.

No. 15.-The Chrysalis of the Wood White But. terlfy.

PIERIS DAPLIDICE (the Green Chequered White) was, till recently, made a separato genus (Mancipium), though some British Entomologists have proposed making it form, with E. Cardemines, a section of the gems Pienis. The alliance with $E$. Curtemines was opposed; the green mottling of the underside of the hind wings common to both these insects being deemed too trivial an affinity to form the basis of a generic relationship, especially when the peculiar form and general character of the chrysalis of $E$. Cumlemines was taken into consileration; but Daplidice has since been united to the Picrilcs, leaving $E$. Curdumines to form a separate genus. Upon cxamination, this arrangement will be found tolerably satisfactory, as $P$. Dupliclice exhibits many of the typical characters of the Picriles, with which it is more strongly linked by the intermediate species $P$. Pe(t)e, and more especially $P$. No(t)i, lescribed in the last Plate. Mr. Westwood notices the angularity and slightly indented margin of the anterior wings of the males of P. Daplidice, while those of the females are more blunt at the angle, and rounded in the external outline, a peculiarity observable also in the male and female of $P$. Nipi. The antennæ also of that species, in the sudden flattening of the club, strongly resemble those of $P$. Duplidicc. The male of P. Daplidice (No. 1) is distinguished from the female (No. 2), by the absence of the second black spot on the fore wings. The fine green chequering with which the underside of the hind wings is pencilled, and from which the popular. designation of this beantiful insect is derived, is shom at No. 3. I have taken the Caterpillar (No.4) described by Boisduval rather. than that described by Hübner, as it agrees better with the accounts given of its appearance by continental collectors, which we must be content to rely upon till this insect has been discovered in the larra state in England, of which at present there is no record. The Chrysalis (No. 5) accords pretty closely with those of the other species in the genus Picis, though it is of somewhat shorter, thicker, and rounder proportions. The Caterpillar is found on the Continent at two seasons, Spring and Autumn, at nearly the same periods as those of the Common 'Whites,' and the insect is very common in the south of Europe, though so rare with us. It is said to feed on the Wild Mignonette, and also on several cruciferous plants of the Cabbage tribe; and is generally found in dry and sandy situations. With us it is one of the greatest of our Euto-

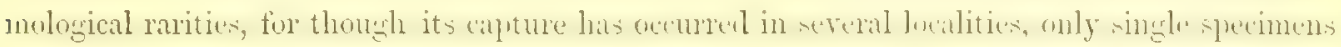
have been taken. I have more than once listened to the late Mr. F. Stephens' interesting account of his capture of the famous specimen in lis fine Collection, which took place in the month of Augnst in the year 1818, in a meadow behind Dover Castle, where another specimen has since been taken. White Wood, near Cambridge, is celebrated as one of the localities for

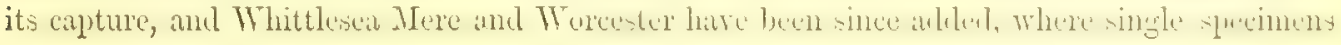


have also been obtained. Some have imagined that one of the old names of this insect "the Batlı White, was given on account of the first British specimen having been taken near that city, but Lewin clearly states that it was from a piece of needlework executed at Bath, copied from an insect, which was only said to have been taken in that neighlooulood; it was most probably a continental specimen.

The genus Euchloe is distinguished from Pieris by the more romded form of the wings, and their less rolust character; also by the distribution of the nervures, and some minute distinctions in the palpi. It differs more strikingly in the preparatory stages, the Caterpillars being much more slender, and the Chrysalis of the distinct form termed boat-shaped; Jeing equally pointed at both ends, very hard and stifo, and entirely withont the ustral segmental joints. It is shing with the head downwards. The name is derived from the Greek words cu (Eu) very, and chloe ( $\chi^{\lambda}$ on) green, in allusion to the remarkable green mottling of the unclersite of the hind wings. There is only one British species.

Euchloc Curtumines is one of our prettiest species; the fore wings of the male (No, 6) are beantifully marked with a broad patch of orange, extending from the tip to near the centre. The female (No.7) is without these conspicuous marks of orange, but has the black spot in the centre of the anterior wings rather larger; in other respects the markings are the same as those of the male; the remarkable green mottlings of the underside of the hind wings (as shown at No. 8) being equally strong in both sexes. The Caturpillar (No. 9) feeds in preference upon the Curlunine imputicus, or Tumitis glutur, to which its singular Chrysalis is generally attached, as shown at No. 10. The perfect insect appears in May, but sprecimens are frequently seen as late as the end of July.

This pretty insect is very ant to rary in its markings, female specimens having been taken with an orange mark on the under side of the fore wings; others with the black spot nearly, if not entirely alusent; while in others an additional black spot appens in the hind wings.

The genus Leucophesiu. The insects assigned to this genus bear such remarkable affinity to those included in Euchloc, that for the sake of not multiplying generic names they might have been conveniently classed with that genus. The rounded form of the anterior wings, and the form and colouring of the Caterpillars, as well as the boat-shaped Chrysalis, marks at once their close relationship. Distinctions of a rery well defined character nevertheless exist, such as the remarkably short liscoidal cell in the nerrtures of the wings in Lcucophasia, from which the branching nervures are consequently of unusual length, and rather peculiar in their distribution; while the Chrysalis, though of similar form to that of $E$. Curdemines, is not so mueh bent in the middle, and has the segments enclosing the abdomen movealble. The proportions of the Caterpillar are rather shorter and thicker than those of $E_{\text {. }}$. Cardumines, but the body of the perfect insect is more slender and long.

Leucophasiu Sinapis (the Wood White, No. 11) is a very local though not a rare insect. The female, (No. 12) is senerally, though not always, without the broad blackish mark at the extremity of the fore wings. The colouring of the uncler side, which differs slighty from the upper, is shown at No. 13. The Caternillar (No. 14) feeds upon Ficiu craceu, and also upon sereral of the common species of Lotus fouml in woods. The Chrysalis (No. 15) is suspended in a similar manner to that of $E$. Curdumines, and the perfect insect appears in May. There is also a second brood which appears in August. This pretty insect may be at once recognised hy its slow and undulating flight, and from its preference of the shaded glades of wools rather than the open sumshine. It has been taken in plenty in the Kentish woods near Pembury, and in similar situations in the neighbourhood of Teigmonth, Stowmanket, and Worcester. It is probable, therefore, that it will be found in many other sheltered woody localitics. It seems, however, only to make its appearance in certain situations periodically, as its capture is once recorted by Mr. Stainton in great abundanee at Lyndhurst, though not usually occurring there. 



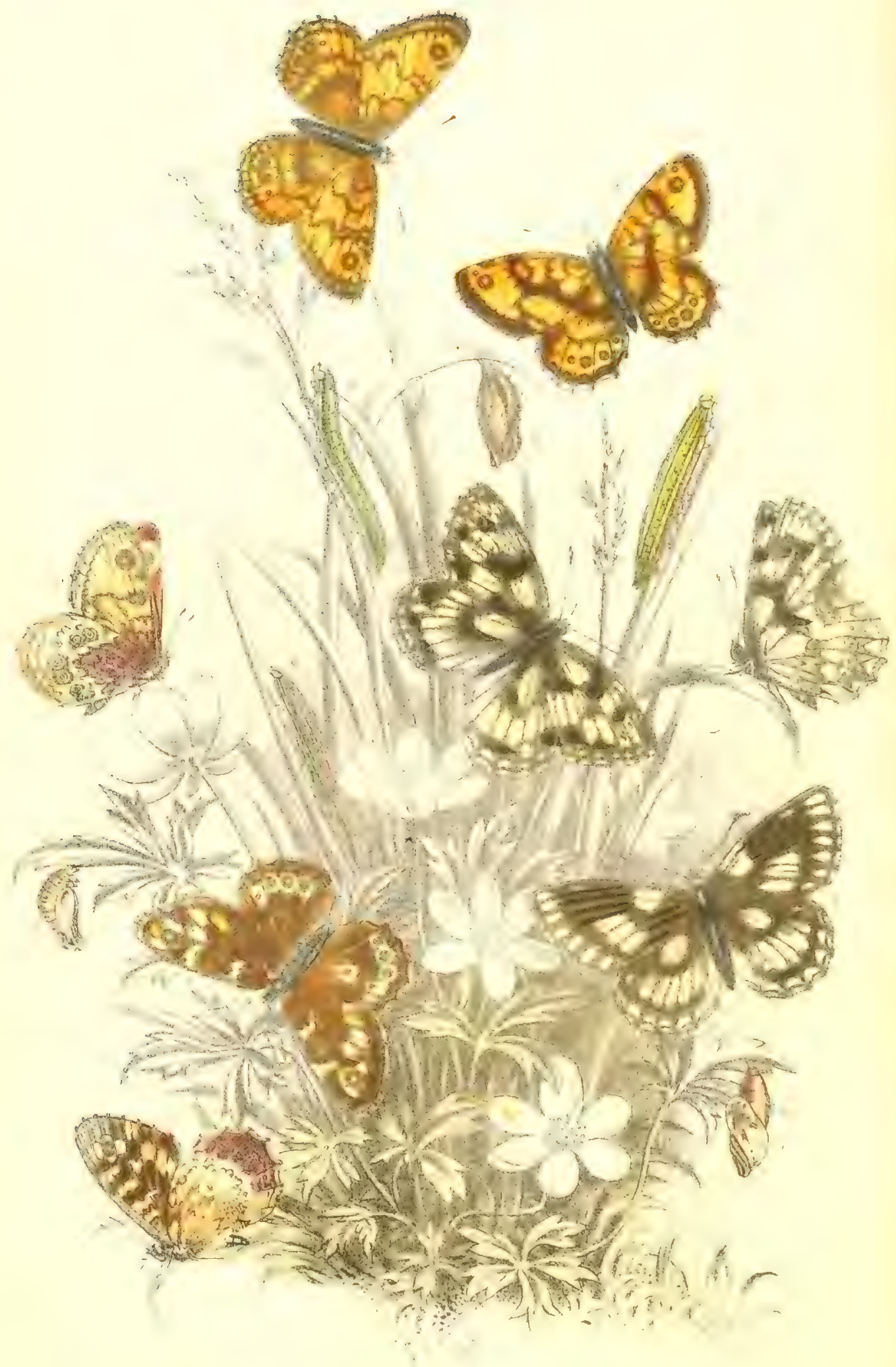




\section{PLATE VI.}

No.1.-The IIarbled While Butterly (Arye Galathea).

No. 2.-The Underside of the Mrarbled White Butterily.

No. 3,-A Variety of the Marbled White Butterfly.

No. 1.-The Caterpillan of the Marbled White Butterfly.

No. 5.-The Clirysalis of the Marbled White Butterils.

No. 6.-The Speckled Wood Butterlly (Lasiommala Eyeria).
Lio. 7.-The Uncter side of the Speckled Wood Butterlly.

No. 8. -'l'he Caterpillar of the Speckled Wood Butterilly.

No. a.-The Clirysalis of the Speckled Wood But. terfly.

No. 10. - The Wall Butterfly (Lasiommata Megara).

No. 11. - The Female of the Wall Butterdy.

No. 12. -The Under side of the Wall Buttcrily.

No. 13. - The Caterpillar of the Wall Butterty.

No. 14.-The Chrysalis of the Wall Buttertly.

TuE second Family of Butterflies is that of the Aymplulide, which is distinguished by having only four legs fitted for walking; the front pair being always, more or less, of mercly mdimental character. The Caterpillars are considerably attentated towids ench extremity, and lave either a fork at the tail or two horn-like appendages at the head. The Chrysalis is suspended by the tail only, having no belt of silk round the body.

The first Sulj-Family of the Nymphatide, as that of the Sutyrili, contains the six genera, Arye, Lasiommate, IIipprerchie, Enodia, Erebia, and Canomympha.

The genus Arge is distinguished, like all those of this sub-funily, by the rudimental character of the front pair of legs, and also by the dentation, or rather scallop-like mululation of the hind wings. The larve have the body slightly thickened in the middle, and attemuted at each extremity, the tail being forked. The Chrysalis is without spines or tubercles, and is suspended by the tail.

Arge Gulathea (the Marbled White, No. 1) is very local, but abundant enough in many fuvourable situations. The under side ( $\left.\mathrm{No}_{2} 2\right)$ is paler than the upper, and rather differently marked. The female is generally somewhat larger than the male, and the ground colour of the wings is yellower. The variety (No. 3) is one of the most unusual; there are other varieties of more common accurrence, among them, one in which the dark marks, instead of being black, are of a fine light brown. There is a fine specimen of this variety in the British Museum. In some varieties the marks of the underside are nearly alssent. The Caterpillar fects in preference on Timothy-grass, but is also found in other grasses growing in woody situations. It ap. pears in June and July, flying in damp open places in woods, in a wavering and Inzy manner, upon which habit it is possible that Esper founded his generic name, Arge, from Argos (Asyos), indolent. It is taken plentifully near Blandford, Brighton, Kingsbury, \&c., \&co, and less abundantly in many other places, but has not yet occurred in any part of Scotland.

The genus Lasiommato is distinguished from the preceding and other nearly related genera by the peculiar character of the eyes, which are covered with short hairs, a character upon which

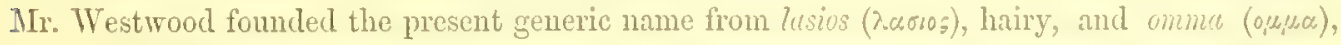
an eye. The front pair of legs are much more conspicuous than in Arge, and are of equal 
length in both sexes, though not fitted for walling. The Caterpillar is attenuated at cach cxtremity, with two short points at the tail. The pupa is short and thick, and furnished with several angular projections, especially two, much more conspicuous than the others, near the head. It is suspended only by the tail.

Lasiommatic Egcriu (the Speckled Wood, No. 6) is one of the commonest of our brown Butterflies. It is subject to considerable variations in the intensity of its marks, but no rery striking varieties occur. The under side (No. T) is very pleasingly varied in the tones of colour. The females are generally more brightly markert, and lave the patches of light colour in the upper surface of the wings more extended than the male, and they are generally somewhat larger than the other sex. The Caterpillar ( $\mathrm{No}$. 8) feeds on Triticum repens, and other common grasses, from the blades of which the Chrysalis (No.9) may often be found suspended. The perfect insect appears in April, June, and August, there being three or more broods in the year. It is common everywhere, generally frequenting shady lanes and hedgerows in preference to open meadows.

Lasiommata Megrom (the Wall, No. 10) is the only other species of this genus. It is as common as the preceding. The male (No. 10) is always much smaller and more strongly marked than the female (No. 11). The uncler side of this species is very beatifully decorated with delicate rings, encls of which enclose aseries of smallel circlets, most perfectly and delicately pencilled, as shown at No. 12. The Caterpillar (No. 13) feeds upon various grasses, and is foumd in May and at the beginning of August, but must be sought at nights with a light, like most of those belonging to this group. The perfect insect appears in April and again in the Autumm. It frequents shady lanes and hedgerows, like L. Egron. 



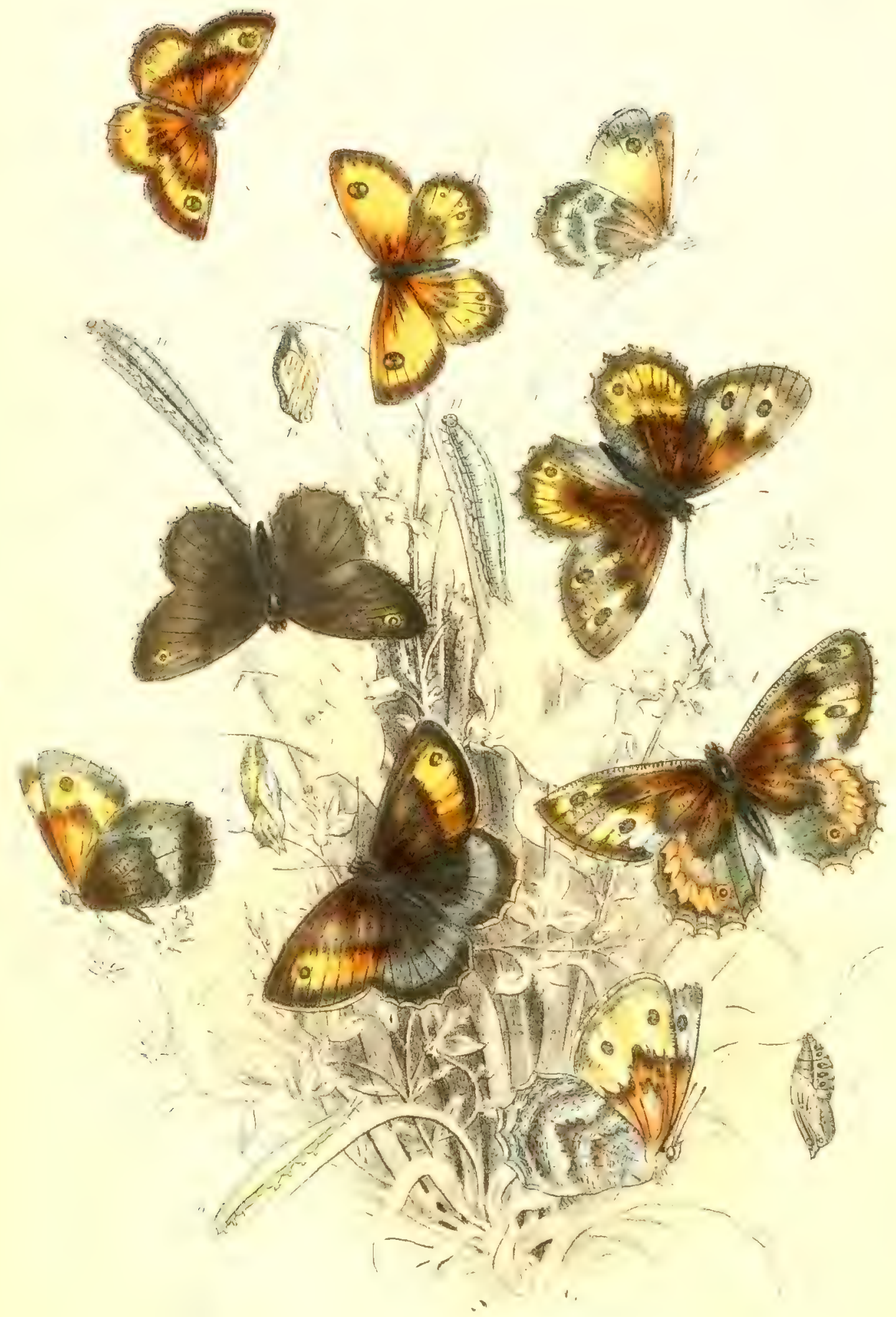




\section{PIATE VII.}

No. 1.-The Grayling Butterfly (Hipparchia Semele).

No. 2-The Female of the Grayling Butterilfo

No. 3.-The Under side of the Grayling Butterly.

No. 4.-The Caterpillar of the Grayling Butterfly.

No. 5. - The Chrysalis of the Grayling Butterly.

No.6.-The Meadow Brown Butterly (Ilipparchic Janira).

No. 7.-The Female of the Meadow Bromn Butterfly.

No. 8. The Under side of the MIeadow Brown Butterfly.

No. 9.-The Caterpillar of the Meadow Brown Butterily.
No. 10.-The Clursalis of the Menclow Brom Butterily.

No. 11.-The Gate Keeper Butterly (Mipparchia Tithonus).

No. 12.-The Female of the Gate Ficeper Butterly.

No. 13.-The Under side of the Gate Keeper Butter115.

No. 14.-The Caterpillar of the Gate Feeper Butter$11 y$.

No. 15.-The Chrssalis of the Gate Iiceper Butter. 11y.

THE genus Hipparchia is distinguished from the preceding one by the smoothness of the cyes, which are entirely free from the clothing of hair which distinguishes the Lasiommate. It is also distinguished by the thickening of the nervures at the base of the fore wings. The hinder pair of wings are denticulated at the fringed edge. The antennas are slender in all the species, but varying considerably in the size and obtuseness of the club. The front pair of legs are smaller than the others, and unfitted for walling, but distinctly visible in both sexes; those of the males being more clothed with hair than those of the females; the tarsal portion being simple in the males, but articulate in the females. The larva are attenuated at eacl extremity, the tail being slightly forked. One species undergoes the changre to the chrysalis stage in the ground, forming a cocoon of particles of earth and silken web. In the other kinds the Chrysalids are suspended by the tail to blades of grass, \&c. There are three British species, Semele, Janira, and Tithomus.

Hipparchic Scmele (the Grayling, No. 1) is by fur the largest of the genus, frequently measuring two inches and a-half across the expanded wings. The markings of this Irandsome insect vary very considerably, both in size and intensity; the light markings in the male (No. 1) being sometimes so much darker than in ordinary specimens as to be scarcely distinguishable from the ground colour. In the female (No. 2) these marks, as well as the black circlets or ocelli, are always much larger and more conspicuous than in the males. The under side of the Grayling (No. 3) is very elegantly varied, both in the tone and in the character of the markings,

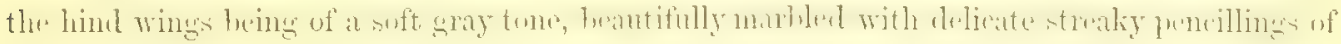
a deeper colour. The Caterpillar (No. 4) appears early in the Spring, and fects on several kinds of our common grasses, and according to M. Marloy's account, in the Annals of the Entomological Society of France, retires into the earth to undergo its change, where it forms an earthen cocoon. In my Plate I have represented the Chrysalis (No.5) suspended to a blade of grass, according to the habits of others of the species, as I have never seen a clrrysalis of the species while still clothed with its cocoon. I have no doubt, however, that M. Marloy is correct in his statement. Those who wish to rear this species from the larva stage should (in localities where the insect abounds) seek the Caterpillars at night, with a Iamp, as they are night feeders, concealing themselves in the daytime, either in the ground or about the roots of the grasses on 
which they feed. The perfect insect appears in July, and though rather local, is by no means rare. The neighbourhoods of Brighton, Bristol, Exeter, Plymouth, and Teigmmonth, are cited in localities where it may be taken abundantly; and in many others it is very far from uncom. mon, even as far north as Edinburgh.

Hipparchic Junira (the Mealow Brown, No. 6) is perhaps the commonest of all our nativo Butterflies, not even excepting the 'Garden Whites.' The meadows, in May and June, are quite alive with this abundant insect, and no variety of season appears to influence its time of appearance or its numbers. The male (No, G) is entirely of one unbroken tone of rich dark brown on the upper surface, with the exception of a small and somewhat obscure circlet of black and orange, having a white speck in the centre, which speck is sometimes double. Singular varieties occur, however, in which the central portions of the wings are nearly denuded of the feather-lilie scales, and are therelyy rendered partially transparent. I have also seen a variety in which the whole upper surface of the wings was but very slightly clothed, and of a pale drab colour, insteal of the usual rich brown. The female (No. 7 ) has the black circlet of the anterior wings surrounded with a fine orange patch, more or less mottled, and a distinct and broad border of a deeper colour round the hind wings. Deceived by this difierence of markings, Linneus mistook the sexes for distinct species (as in many other similar instances), calling the male Papilio Junira, and the female Papilio Jurtina. In such cases, when the error is discovered, it is the specific name of the male that is preserved, so that, although Linneus's great genus or class Pupilio las been subdivided into numerous families, sub-families, and genera, we have still his original name Junira, preserved in the denomination of this species, as Hipparchia Janira. The under side (No. 8) is nearly alike in both sexes. The Caterpillar (No. 9) feeds on grasses, and suspends itself by the tail to undergo the ehange to the chrysalis stage. The Chrysalis (No. 10) is double-pointed at the head. The perfect insect appears throughout the Summer, and is common everywhere.

Hipperchic Tithonus (the Gate Keeper, No. 11) is nearly as common as the preceding. The male (No. 11) is much smaller than the female, but more richly coloured, some being much darker, and generally of a richer tone than the one represented, which is a medium specimen. The female (No. 12) scarcely varies at all in its colour or markings, but the dark border of the wings is sometimes rather paler and narrower than in the specimen represented. On the under side (No. 13) the sexes closely resemble each other, the males being sometimes rather darker. The Caterpillar (No. 14) is found feeding on grasses early in June, and when full fed it suspends itself by the tail to undergo its change. The Chrysalis (No. 15) is of short, thick form, the back being of a dark olive, but beneath, to the extent of the wing-cases, of a much paler colour. The perfect insect appears in July. It is very common, though becoming somewliat more rare in the morthern comities, and not being found at all in Scotland. 


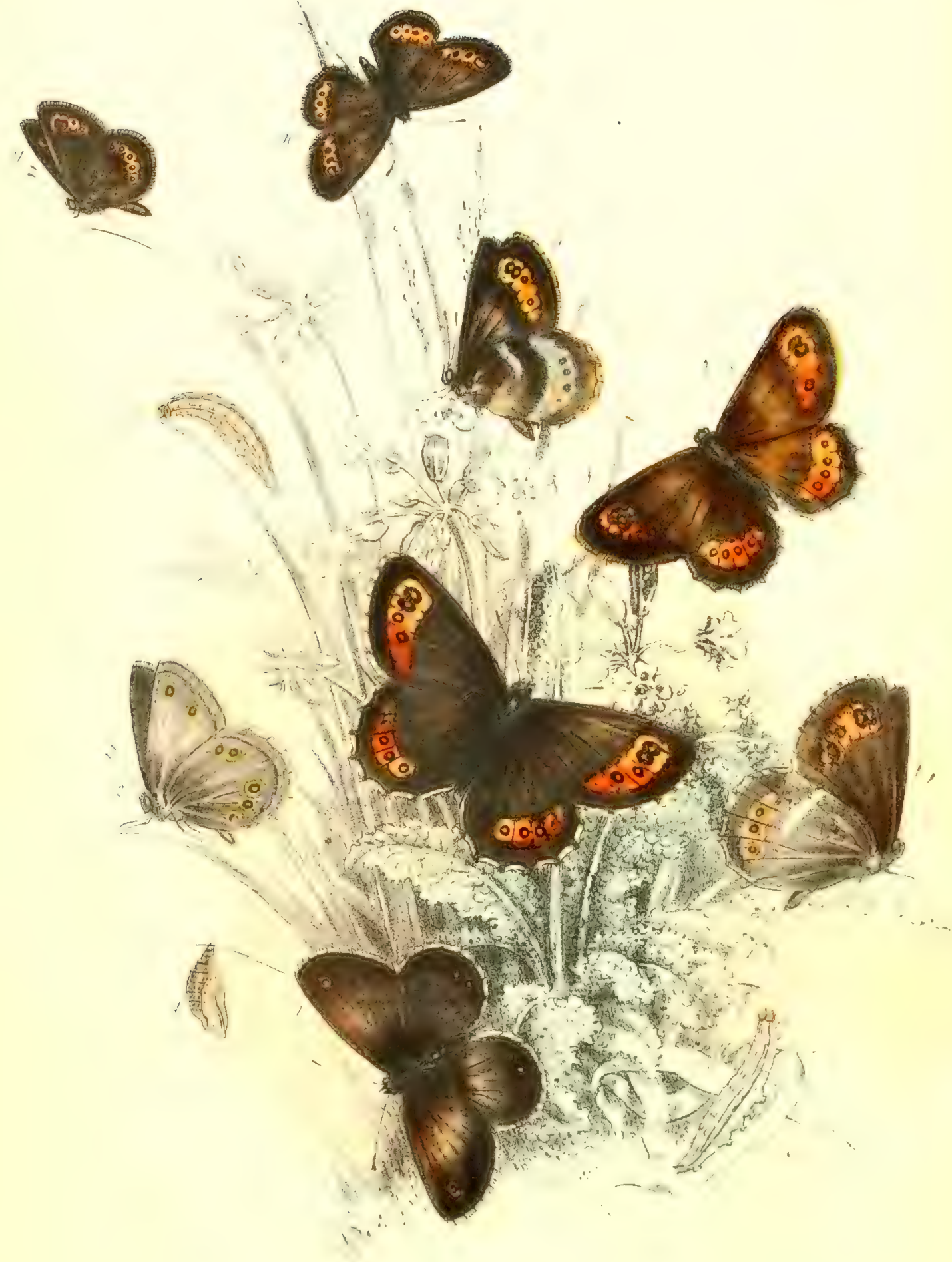


\section{PLATE VIII.}

No. 1. The Ringlet Butterfly (Enodia Hyperanthus). No. 2.-The Ringlet Butterly, showing the Under side.

No. 3.-The Caterpillar of the Ringlet Butterfly.

No. 4. - The Chrysalis of the Ringlet Butterlfy.

No.5.-The Searce Scotch Argus Butterfly, tho Femalo (Erelia Ligea).

No. 6.-The Male of tho Scarce Scoteh Argus Bntter. 1ly, showing the Under side.
No. 7.-The Caterpillar of the Scarce Scoteh Argus Butterfly.

No. 8.-The Scotch Argus Butterfly, the Femalo (Erebia Blandina).

No. 9.-The Male of the Scoteh Argus Butterfly, sliowing the Under side.

No.10.-TheSmall Riuglet Butterfy (Erebia Cassiope).

No. 11.-The Small Ringlet Butterfly, showing the Under silo.

The genus Enoric of Hüloner contains a group of insect closely allied to those of the gitnus Irippentiu of Fabricins, from which the commen linglet Butterfly has been recently remoret to

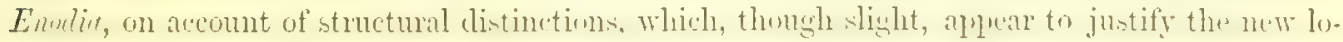
cation of this insect. It is, howerer, hy sune Linglish entomolngists still retainen in its ald position.

Enotic IIyperanthus (the Ringlet, No. 1). This common Buttertly, thongh not quite so abundant as one or two other species of Nymphalide, is yet found very plentifully in damp grassy places, and in shady lanes and the borders of woods, in all parts of the country. The under side, as represented at No. 2, is very beautifully marked with a series of ocelli, or small rings, from which it takes its popular name, the 'Ringlet.' There is lout little difference, eitler in size, or in the markings, between the male and female of this species; the latter seems, however, to have, very frequently, three distinct ocelli on the upper side of the front wings, while in the males, only une, or sometimes two, are distinctly visible, and they are sometimes entirely alsent. This insect is, indeed, subject to considerable variation in its markings, in both sexes. On the under side, for instance, the rings or circlets are so large in some specimens as to be joined tugether, occasionally having smaller athlitional ocelli attacterl to them, whilw in other instances the ocelli are so nearly obliternted as to be only represented by small white specks. The Caterpillar (No. 3) feeds upon Millet Grass, or upon Poa Amua, the common annual Meadow Grass. It takes its ford at night, concealing itself alsout the routs during the day. The Chrymalis (No. 4), which is shorter, thicker, and smoother, than those belonging to the genus Iipparchic, is suspended by the tail.

The genus Erebia is distinguished from Hipparchic by having only one of the nervures of the anterior wings thickened at the base. The fore feet, in the male, are so small, as to be scarcely visible, while in the female they are comparatively long, and have the tarsal portion articulated. The lind wings are slightly denticulated. Dolman's generic term Erebia has been preferred to Mr. Westwood's Orcint, on the ground of its priority, and as being in accordance with the most accredited continental systems of classification.

Erebia Ligea (the Scarce Scotch Argus, No. 5). This fine insect can scarcely be considered

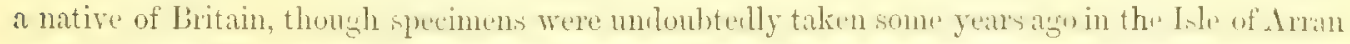
lyg Sir Patrick Wallere and Alexander Macleay, Esc. Accilental captures of that linel are not sufficient, however, to prove any insect to be a native. It may either be a wanderer, brought over from the Continent on the wing during a wenterly gale, or may haw heen importer in the "gge, or puna, state in foreign vessels, as is certainly the case with the two fine Splhinger, Deiti- 
gitilu Liromica and Cheroctmpre Celerio, as well as many other lepidopterous insects, occasionally taken in the British Islands, and placed in onr entomological cabinets as British. This species of Enctir may be at once recognised by the collector lncky enough to meet with it, by the deep white fringe, interrupted by brown, at the juncture of the nervures; the fringe in all the other reputed British species being brown. The male ( $\left.\mathrm{No}_{0}, 6\right)$ is smaller than the female, and has the circlets on the upper sicte of the antcrior wings less distinct, and without the central specks of white. A single pair of Erebia Ligen are the only specimens in the collection in the British Museum. It is said to be a Swedish insect, and if so, the specimens taken in Arran may possibly have been wanderers from that country. The Caterpillar is figured at No. 7 .

Erebia Blentina (the Scotch Argus). The specimen figured at No. 8 is a female, laving the orange marks, and the circlets with white contres more distinct than in the males, as shown in the representation of the male specimen at No. 9. The fringe is brown, like the general upper surface of the wings, but rather paler in the female. In the figure No. 9 the coloning of the under side is shown, which varies in the sexes, and also to some cxtent in different specimens; but it is always without the distinct white mark which distingruishes the last-described species. The Caterpillar is described as light green, with brown and white longitudinal stripes, but no trustworthy representation has yet been published. In Mr. I. F. Logan's forthcoming "Illustrations of S'cottish Lepidoptera," however, we shall probably be male acquainted with the details of the transformation of this and many other of the rarer species of British Lepidoptera occurring only in tho North. In England it has been taken in some profusion in the magnesian limestone districts near Newcastle, in the neighbourhoorl of Kendal, and at Colne, and also at Wharfdale in Iorkshire, and a few other places. In Scotland it is found in the Isle of Arran and several other localities; and occurs more especially, in some abundance, over a district of considernble extent in Dumfries-shire. Varieties occur in this species, both as to the distinctness and number of the ocelli.

Erebiu C'ussiope (tle Small Ringlet, Nos. 10 and 11). This pretty species differs considerably from the two preceding, not only in size, but in the elongated proportion of the wings, and in the absence of denticulation in the fringed edge of the hinder pair. It also differs in the markings of the under side, which are of a similar colour to those of the upper surface, and without any of the gray tones which distinguish the two larger species. It has been taken at various places in the mountainous parts of Westmoreland and Cumberland; the males apperring about the middle of June, the females not till somewhat later. It must always be sought at a considerable eleration on the mountain sides, and generally in damp and grassy recesses. In Scotland it is found in many parts of the Sonthem counties, and as far North as Ramock in Pertlshire; and probally, if well sought for, even to the most Northern extremities of the Highlands, in favourable situations.

Only three species of this interesting genus are at present admitted into the English lists, but others doubtless exist, and will be diseovered by enterprising explorers among the mountains of Wales or Wicklow, or many of the Scottish ranges, as yet not half explored. On the Continent, in precisely similar situations, eighteen or twenty species are found, and few of them are especially rare. I think I counted full that number in the collection of the late lamented M. Pierret. In the varions momtain districts between Grenoble and Mont Cenis, which I made the scene of a summer ramble a few summers ago, the dark rich brown of many species of this pretty family of Buttertlies quite tinted the green slopes of that Alpine region with various tones of brown; which, however, disappeared almost instantly whenever a passing cloud ouscured the sum, every insect settling among the grass, and becoming invisible till another gleam of sunlight brought them out again. I collected many species and rarieties, but having no entomolological apparatus with me, my specimens became so much injured in travelling as not to be worth preserving. 



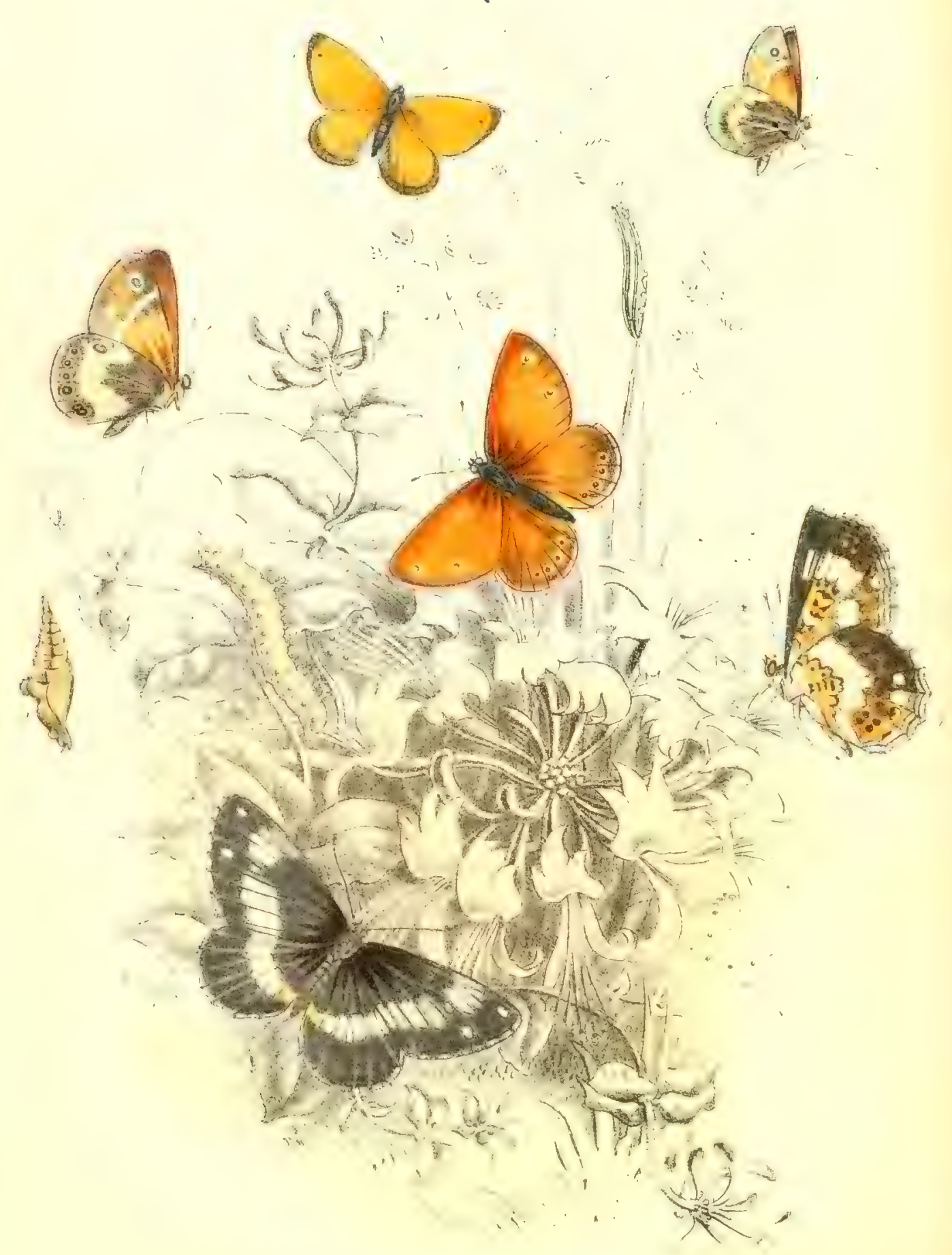




\section{PLATE IX.}

No. 1.-The Marsh Ringlet Buttertly (Cenonympha Davies).

No. 2.-The Marsh Ringlet Butterfly, showing the Under side.

No.3.-The Small Heath Butterfy (Conomympha Pamphilus).

No.4.-The Small Heath Butterfy, showing tho Under side.
No. 5.-The Caterpillar of the Small Heath Butterfly.

No. 6.-The White Admiral Butterfly (Limenitis Sibilla).

No. 7.-The White Admiral Butterfly, showing the Under side.

No. 8.-The Caterpillar of the White Admiral But. terfly.

No. 9.-The Chrysalis of the White Admiral Butterfly.

Tire genus Conomympha contains two of the smaller kinds of the well-defined sub-family grouped under the title of Satyridi. The hind wings are not denticulated at the fringed edge. The anterior wings have three of the nervures much enlarged or swollen near the base. The nntennx are annulated with grey and brown. The larve are quite smooth, and shining.

Canomympha Darus (the Marsh Ringlet, Nos. 1 and 2). This pretty Heath Butterfy, only found in the North, is very variable in its markings, especially in different localities. This circumstance led our earlier collectors (at a time when few specimens were found in collections for comparison) to imagine that several distinct British species closely allied to Darus existed; and some of the varieties received the specific names, Typhon, Polydama, Iphis, \&c., two dark varicties being named respectively Hero and Ascanius; all of which are, I think, satisfactorily proved to have been merely varieties of $C$. Durus. The dotails of the transfomations of this pretty species are at present but imperfectly known. It has been taken plentifully in the marshes between Stockport and Ashton, and at Trafiord. Whitemos, in the neighlourlumel of Manchester, and also on some of the marklyy moors of Yorkshire; Thorn Mrow and Hatfeld Chase, for instance. The Pentland Hills and uther places in Scotland, are recorded as localities where it has been captured more recently.

Canonymy hu Pumphitus (the Small Heath, Tos. 3 and 4). This is one of the commonest of our native Butterflies, while its near relative, $C$. Durus, as we have just seen, must le rankerl among the rarest. The Caterpillar (No, 5) feeds on several common meadow grasses, hut in preference upon the Poo anmu or the crested Dog's-tail grans, Cynosurus C'ristutus. It is common everywhere, in favourable situations.

The second sulb-family of the Nympheliter, distinguinhed as the Nymphalidi, contains two British genera, Limenitis and Aluture, each representex hy a single species, ranling in hoth cases among the most remarkable of our native Li pituph in, especially A future Iris, which may perhaps be considered the crowning jewel of a British collection.

The genus Limenitis, in the perfect state, appears very closely related to Apatura, but is distinguished from it by the following characteristic. It is generally of lesis robust formatim, and the fore wines are rounded at the extermal eder insteat of heing partially concave as in Apature: the hind wings also are more rounded : the more gradual formation of the clul, of the antenne is another good generic distinction. In the larra state the distinction is much more. marked; the Caterpillar having several pairs of fleshy spines on the back, each cluthed with fine 
Iristles, a feature which is entirely alosent in the larva state of Apatura Iris. The pupa is beaked, and suspended by the tail.

Limenitis Sibillu (the White Admiral, No. 6). This is one of our handsomest native Butterflies. When on the wing, its fine sailing motion displays the striking contrast of its black and white markings to great advantage, forming a tempting prize to the eager Lepidopterist. Haworth relates that an old London collector, long after he was able to pursue an active Butterfly, would go to the woods where this species then abounded, for the sole purpose of "feasting his eyes with its fasciuating evolutions." I first saw this beautiful insect in Italy, in a vineyard near Rome, and was almost as much delighted as Haworth's enthusiast; but the capture of several specimens in a few hours, for it was very plentiful, soon decrensed the intensity of the attraction. The under side (No. 7) resembles, in its delicate gray, white, brown, and orange markings, the under side of Apaluru Iris, which it almost rivals in beauty. The Caterpillar (No. 8) feeds on honeysuckle. The Chrysalis (No.9) is curiously formed, and has the metallic markings which distinguish the pupe of the next sub-family, that of the Fancssilli. The perfect insect appears in July, and is now a rare species, though once tolerably abundant in many of the Sonthem Counties. The wooks near. Winchester were formerly a celebrated locality for this fine Butterfly. The places cited for its most recent capture are Elping, Bere Regis, Colehester, and Black Park. At Lyndhurst it occurred in abundance a few seasons ago, but it is not usually taken there. It has also appeared at intervals near Worcester, Tenterden, and in other districts. 


\section{PLATE X.}

No. 1.-Tho Purple Emperor Butterfly (Apatura Iris), the Male.

No. 2.-The Female of the Purple Emperor Butterfy. No. 3.-The Under side of the Puplo Emperor Butterfly. Nos. 4 \& 5.-Caterpillars of the Purple Emperor
Butterfly.

No.6.-The Chrysalis of the Purple Emperor Butterfly.

THE genus A peture is clistinguished by the thickness of the antemax, or by their gractual thickening towards the club or knob at the tip, and lyy their lesing nearly straight, instean of slightly curved as in all the allied genera. The wings and body are robust. The hind-wings being slightly scalloped, elongated rather than rounded at the angle next the body, and having at the posterior angle an ocellated spot. It is, however, more distinct from neighbouring genera in the preparatory stages than in the perfect state. The Caterpillar is very peculiar, having somewhat the form of a slug, the likeness to which is much heightened by the two erect spines at the head, which resemble the retractile 'horns' of the snail family. The Chrysalis is suspended by the tail, and is much like the Caterpillar in general form, but is, of course, much shorter and thicker ; and it is forked at the head like some of the pupx in the genus Iripparchia. There is but one British species, the beautiful Purple Emperor.

Apatura Iris (the Purple Emperor, No. 1) is perhaps, on the whole, the most splendid of our native Buttertles. The heautiful purpl' ghos exhihited hy the male insect, in certain lights, especially when flying downwards, being almost equal in brilliancy to that of some of the magnificent Butterflies of South America. When not seen in the proper light, this fine purple flush disappears, and the dark portion of the wings assumes a rich brown, like that of the female (No. 2), which is entirely devoid of the iridescent lustre which distinguishes the male. On the under side of the wings both sexes are nearly alike, and fully as attractive, though after a very distinct fashion, as on the upper surface. In the beautiful shades of white, gray, brown

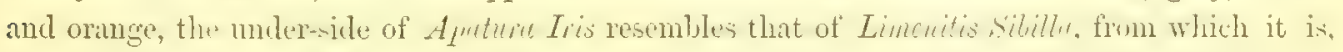
however, distinguished ly the purple-centerend circlet at the ponterior angle of the hind-wings, and more especially by the large purple and orange ocellus in the fore-wings, the outline of which is distinguishable on the upper side.

The Caterpillar (Nos. 4 and 5) is of a soft apple-green, delicately varied with diagonal streaks of yellow, the head being tinted with pale lilac. It is to be sought in the month of May, when, in favouralye situations, the fortunate collectur maty find it feeding on the broadleaved sallow. This Caterpillar was first discovered by Mr. Drury, the well known English Naturalist, in the following manner, as described by his brother naturalist, Moses Harris. "That ingenious Aurelian," as Mr. Drury is termed by his friend, while searching for Caterpillars, near Brentwood, in Essex, on the 26th of May, 1758, beat from off the Sallow some larvæ, which were entirely new to him, and which he presented to Mr. Moses Harris, as the person most likely to rear them sucer-fully. In his curions houk, Harris dercribes very minutely all their stages of derelopment under his care, concluding by infuming us, thit on the $2-2 n d$ of June, 1758, to his unspeakable yleasure, one of his Chrysalicles prudtecd the Purple Emperor; 
and he precests to axpres his mulumeled gratitule to that "ingenions gentleman," Mr. Drurg, who had thus enabled him to discover "the Caterpillar of one of the finest flies in the universe, which har hitherto escaped the search of the most skilful and industrious Aurelians."

The Chrysalis (No, 6) is suspended by the tail, and in colour differs but little from that of the Caterpillar.

The capture of the perfect insect, which appears towards the end of June, or in July, is

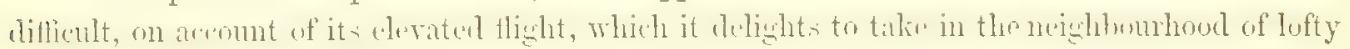
oaks, over the tops of which it skims with a power and rapidity, that seem at first to place it quite out of the reach of the Lepidopterist, even when armed with his rery best appliances, such as a small light net at the extremity of a long, pliable rod, \&c. Nevertheless, the male, a much bolder flier than the female, has been taken on the wing, in this manner. A more successful method, however, is to seek this entomological prize while at rest; when he is often to be found on the lower part of the trunks of large trees. A successful Collector informed me some years ago, that during an entomological ramble in the New Forest, he once sought shelter from an approaching storm under the branches of a spreading oak, and while there, two magnificent specimens of the Purple Emperor bollly came to share his shelter, and alighted on the trunk close to him. It is needless to add, that they both foumd their way into his collecting box. Gloomy weather, with occasional showers, should therefore be selected for the pursuit of the Purple Emperor, watching carefully the trunks of the trees, in farourable situations, whenever the sun becomes suddenly overcast.

The name of the genus, Apature, which was given to it by Fabricits in 1807,* and which should more properly have been Apaturia, is generally said to have been talien from one of the names of Aphrodite or Venus, in reference to the beauty of the insect. But I hare a fancy that Fabricius had in view rather one of the names of Athena, indicating deceitfulness, in reference to the deceptive effect of the purple gloss, which entirely disappears in certain lights.

* Previous to which date our species still remained the Papilio Iris, of Linnæus. 



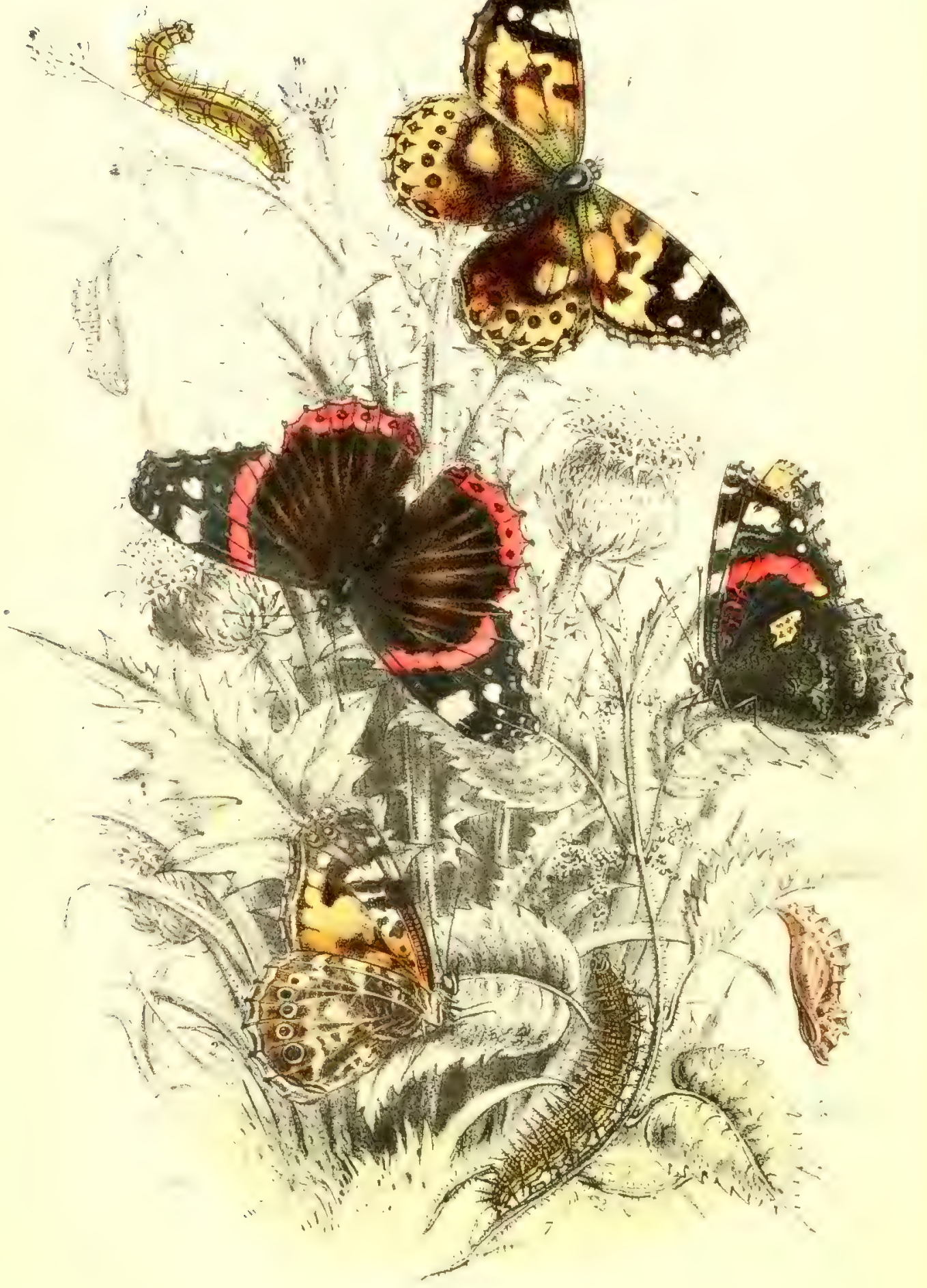




\section{PLATE XI.}

No. 1. The Painted Lady Buttertly (Cynthia Cardui).

No. 2.-Tho Painted Lady Buttertly, showing the under surface.

No. 3.-The Caterpillar of the Painted Lady Buttelfly.

No. 4.-The Chrysalis of the PaintedLadj Buttertly.
No. 5. - The Red Admiral Butterfly (Tranessa Alalanta).

No.6.-The Under surface of the Red Actmiral Butterfly.

No. 7.-The Caterpillar of the Red Admiral Butterly. No. 8.-The Chrysalis of the Red Admiral Butterlly.

TuE third Sub-Family of the Nymphatide is that of the Tuncssill, containing three tolerably distinct genera, all of which are included by some authors in the genus Funcsal. The present sub-clivisions, into Cynthic, Vanessa, and Groph, are foumded upon pretty distinct characters. Cynthic has the club of the antenna shorter and the thickening more abrupt than in any other of the group; and has, in the fringed margin of the anterior wings only a slight and graduated projection near the front angle. In the genus Trmessc this projection becomes more marked, and decidedly abrupt. In the genus Grapta the fore-wings have two such projections, both much more marked than in Vunessa.

The genus Cynthic is distinguished, as above stated, by the abruptness of the clubs of the antennæ, and by the comparative evenness of the outline of the fringed margin of the anterior wings. It is farther distinguished by the character of the palpi, which are somewhat deflexed and beak-like. In the Caterpillar and Chrysalis it closely resembles the true Vuncsse; or, were it desirable to keep it separate from the Vanessce, on account of its affinities with its exotic congeners in the genus C'ynthia, then, one would almost feel disposed to place $V$. Atulcute also in the genus Cynthia, as it only differs from it anatomically in the slightly greater angulation of the projection of the fore-wings, and in the somewhat more gradual formation of the clubs of the antemi, which appear rather specific than generic differences. $\quad$. Atuluntu is, moreover, as clearly separated from the $V$ unesse as $C$. Cardui is, l,y the entire absence of the tail-like projection of the hind-wings, which distinguishes all the typical $V$ unesse. In order to exhibit the affinity of this species with Curdui, I have placed the representation of each on the same Plate, instead of grouping $V$. Atulunta with others of the genus $V$ anessa, to which it is made to belong.

Cynthia Cardui (the Painted Lady, No. 1). This species is remarkable for the irregularity of its appearance; being seen in some seasons in tolerable abundance, especially in the metropolitan counties, while at other times, for many consecutive years, scarcely a single specimen is to be found by the most persevering collectors. On the Continent its appearance secms to be equally capricious. In the Annales des Sciences Naturelles for 1828, as quoted by Mir. Testwood, an account is given of an extraordinary swarm which was noticed in the preceding $N$ iny (the usual time of the appearance of this insect being August), the extent of which was so prodigious that it occupied several hours in passing over the place where it was observed. Similar swarms of the Common White Butterfly (Pieris Brussicce), and also of some other species, have been observed at different periods. I recollect the cliffs between Margate and Broadstairs being completely covered with a swarm of the last-named species, some few years ago. I observed them first in the morning, no trace of them having exi-twd the night hefore, and the filloning 
day they were again dispersed. The markings of Cynthiu Curdui are so like those of $V$. Atalanta, that an inexperienced collector might mistake it for a faded specimen of that species; they are, however, very distinct when closely examined, the reddish-orange marks on the right fore-wing laving been comprared to a mip of England and Ireland, which, in sume strongly marliet specimens, they slightly resemble. The Caterpillar (No. 3) feeds on various plants of the Thistle tribe, and is represented upon a plant of Cnicus lunccolatus (the Spear Plum Thistle). Like the Caterpillar of $V$. Atalanta, it is solitary in its labits, and also draws up the leaves upon which it is feeding in a similar mamer, with wely-like threads. It is also found at the same season, July. The Chrysalis (No. 4) is suspended by the tail, and has the gold-like spots which distinguish all the Sub-Family I tunessidi. The generic name, Cynthio, appears to have been taken, after the arbitrary fashion adopted by Linnæus, from that of a pagan divinity, being one of those of the goddess Artemis, derived from the name of Mount Cynthus, in the Island of Delos, where she is said to have been born; the name Cynthius being sometimes given to her brother Apollo, for the same curse. The specific name, Curdui, refers to a species of Carduus, or Thistle, upon which the Caterpillar frequently feeds.

The genus $I$ conessa. The insects in this genus are rather remarkably distinguished by the hairy clothing of their eyes. They have the outline of the fringed border of the anterior wings rendered more or less irregular in form by one or more angular projections, and the hind-wings, except in the case of $T$. Atalanta, have a short tail-like projection, somewhat analogous to that we have seen distinguishing the Papilionide, thongh much less conspicuous, and which we shall find again in a more slender form in the genus Thecla. The anterior pair of legs are rudimental and unfitted for walking, as in the genus Cynthid. The Caterpillar is furnished with spines. The Chrysalides, which are very angular, exhibit the appearance of gold and silver spots, caused by a fluid which is seen through the transparent external membrane, imparting a metallic gloss to the yellow shell or skin over which it circulates. The name of this genus appears to have been adopted by Fabricius from Phanes, one of the appellations of Eros or Cupid, and would, therefore, be more correctly written Phanessa instead of Vanessa. It was possibly given in allusion to the beauty of most of the species; those which are found in the British Islands not ceding the palm to any of their exotic congeners.

Vanessa Atalanta (the Red Admiral, No. 5). This insect, which might be more conveniently classed as Cynthic Atalanta till the two groups have been thoroughly revised, is one of the handsomest, and at the same time, one of the commonest of our native Butterflies. The under side of the hind wings (No. 6) is very richly marbled with deep brown, and exhibits some slight traces of the rudimental ocelli which distinguish the scarlet border on the upper surface. In Cynthic Cardu, however, these marks become more distinct on the mnder side than the upper, as may be observed on reference to the representation of that insect, showing the under side, at No. 2. This may be made the ground of separating Atalanta and Cardui, otherwise appearing in all respects so closely allied. It is said that the females of $V$. Atalanta lave a small white speck on the red bar near the back of the anterior wings. The Caterpillar of the Red Admiral (No. 7) feeds on the common Stinging Nettle; and the perfect Butterfly appears in August. This fine species occurs throughout Europe, in the North of Africa, and in other distant localities, being a very widely dispersed species. 



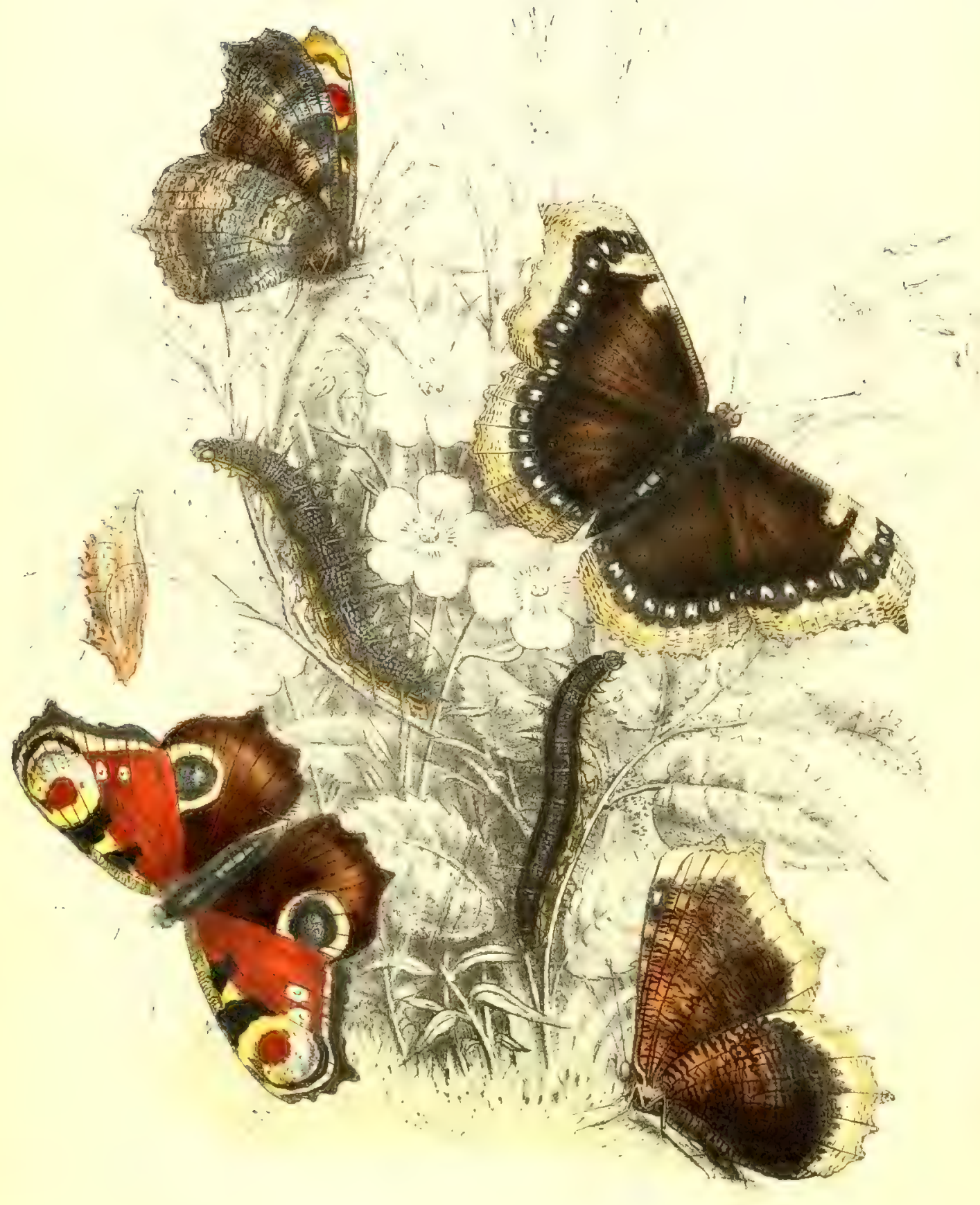




\section{PLATE XII.}

No. 1. -The Peacock Butterfly (V́anessa Io).

No. 2.-The Peacock Butterfly, showing the under surface,

No. 3.-The Caterpillar of the Peacock Butterfiy. No. 4.-The Chrysalis of the Peacock Butterfly.
No. 5. - The Camberwell Beauty Butterty (Ianessa Antiopa).

No. 6.-The Caraberwell Beauty Butterfly, showing the under surface of the wings.

No. 7.-The Caterpillar of the Camberwell Beauty Butterfiy.

VANessa Io (the Peacock Butterfly, No. I) is the most beautiful of the species grouped together in the genus $V$ anessu, of which some authors consider it the type ; but from most of which, as it appears to me, it will very probahly be separated at no very distant period, when this and the allied genera shall be revised, with reference to all the exotic species. This bealtiful Butterfly is extremely common, but its appearance does not extend firther North than the Frith of Forth, being but very sparingly seen even in the South of Scotland. On the under side, the wings (No. 2) exhibit in their dark and sober hues a singular contrast to the glowing colours of the upper surface, the magnificent ocelli of which, with their softly shaded irides, are so remarkable. The Caterpillar (No.3) is gregarious, and groups of them may often be seen in July, forming a large black mass on a bed of nettles, visible at a considerable distance. It has been observed, that in all those species the eggs of which are laid in patches, gummed together, the Caterpillars, when hatched, are gregarious and continue together even when full grown. The transformations of this species formed the subject of one of those courses of minute and persevering observation which have made the name of Réaumur so celebrated among naturalists; the singular mamner in which the Chrysalis attaches itself to the knot of weh established by the Caterpillar before the skin of the Caterpillar is cast off, as deseribed by that author, being one of the most curious exhibitions of instinct in the whole range of natural history. The perfect insect appears towards the middle or end of July, and as it settles upon a flower or on the gravel of a garden path, forms a most beautiful object. It frequently survives the winter, hybernating in some well-secluded shelter, where it remains in a dormant state till

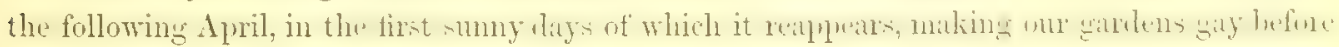
the season of flowers has scarcely commenced: the specimens which thus survive the winter are said to be almost invariably females.

Vanessa Antiopa (the Camberwell Beauty, No.5). This is the largest of the British species of $V$ ancssu, and the rarest; many seasons passing without the capture of a single specimen, though most Lepidopterists (now a pretty numerous class) are always on the look out for the capture of the coveted prize. I never saw it on the wing but once, on the 12th of September, in the year 1855 , when, walking from Watforel to St. Allsn's, I was attratert loy the flight of

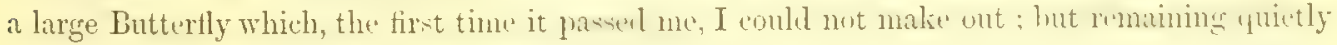
in the same place, it passed me again in a few minutes, having evidently a regular circuit of flight which occupied abont that time, if not delayed by some mun-ual attraction. This time it settled in the middle of the road, at some distance from me, but I smeceedert in approuching it

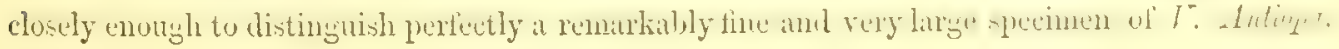


It rose as I approached, and having no net with me, I made a sweep at it with my hat, but unsuccessfully. I waited for its return, which occurred again in about the same time, notwithstanding the alarm it must liave received, but I was again unsuccessful, and, my companion becoming impatient, we pursued our journey, without renewing the attempt, which I have often regretted.

The Caterpilar, which is considerably larger than that of $I$. Io, is beantifully marked with red, at the base of the spines, as shown at No. 7. It feeds on the Willow, and is to be looked for in July. The perfect insect appears in August, the females often surviving the winter, and depositing their eggs in the following spring; in which case they reappear as early as April.

This fine insect has been found as far North as Ajrshire, but is a rarity in any locality except at intervals of eight or ten years, when it appears in some abundance. Abont eighty years ago it was so plentiful, after a long absence, that it received the name, among collectors, of the "Grand Surprise ;" and its appearance at Camberwell, one season many years ago, caused it to be known as the "Camberwell Beauty," - a name it still retains. The English specimens are sairl to differ from those of the Continent, in having the borders of the wings nearly white, instead of cream colour. But this observation may have been made on specimens long preserved in Collections, and probably facted to some extent, as the specinen which I saw alive, as described above, had the borders in question of a remarkably rich and deep cream colour.

This fine insect is the Pupilio Antione of Linneus, who appears to have adopted the specific name from that of a mythical personage, as in many other instances. The clescriptive or otherwise characteristic denominations of more modern systems of classification appear to great advantage when compared with the artitrary nomenclature of the infancy of the science, as exhibited in this and other instances. 


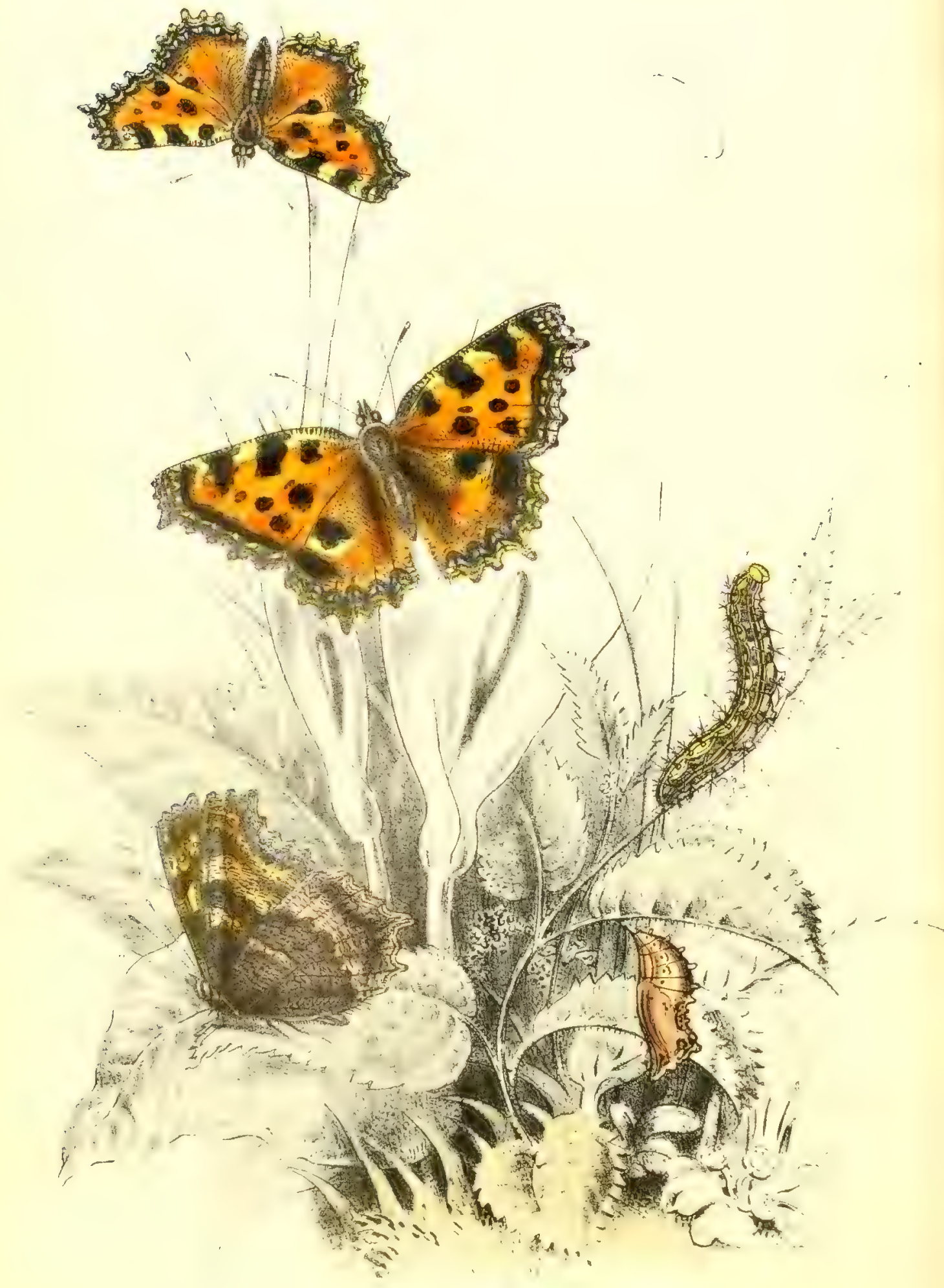


\section{PLATE XIII.}

\section{No. 1.-The Great Tortoise-shell Butterfly (Vanessa} Polychloros).

No. 2.-The Great Tortoise-shell Butterfly, showing the under side.

No. 3.-An unusually small specimen of the Great Tortoise-shell Butterfly.
No. 4.-The Caterpillar of the Great Tortoise-shell Butterly.

No. 5.-The Chrysalis of the Great Tortoise-shell Butterfly.

Vanessa Potychloros (the Great Tortoise-shell Butterfly, No. 1). This fine insect has all the characters well defined that distinguish the genus $V$ anesse; such as the sharp and conspicuous palpi, and the projecting angles of the wings. The Great Tortoise-shell is sometimes very abundant, more particularly roumd London; but in other seasons scarcely a specimen is to be found, especially towards the North. This fine insect is described as appearing in July, and those specimens which are occasionally seen in the early spring are generally considered to consist of such only as have survived the winter in a semidormant state, like those of the allied species, $V$. urtice and $V$. Io. This has been considered the more probable, as the spring specimens often present a worn and faded appearance. That some do survive the winter in the way supposed is certain, as that degree of longevity is a characteristic of the entire genus, and has not been observed as a conspicuous peculiarity in any other genus of British Butterflies. Last spring, however, I had an opportunity of observing the appearance of a number of beautifully

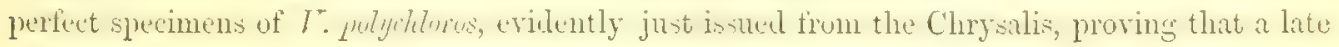
brood occurs in favourable seasons, which remain in the Chrysalis till the following spring, cherging frum the pupa case on the first sunny days in Aarch or April. On the 29th of Arareh,

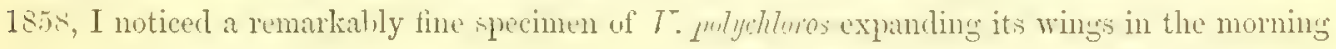
sun on the gravel path in front of my study window. It was evidently quite fresh from the Clurysalis, its wings not having acedured that firmmens of texture which a little more exposture to the sun soon imparted to them. I observed, too, that the colour was paler and more beautiful than in autummal specimens; in fact of a slightly different tone, heing clecidedly nore approaching to a pure orange; which is in fact rather a rich orange buff than the usual tawny brown; and the difference appears to le permanent, for many specincens appeared, and I afterwards remarked that those which had heen some days on the wing still preserved that lighter and more delicate tone of colour. The dark spots, too, are of a deep ruddy brown, rather than dusky black like those that have eclosed in the autumu. Indeed, at a hasty glance theso spring specimens might be taken for a new species, or at all events, a very distinct variety. Some Chrysalides which I collected in the previuns antumn, when they were very alumelant, celoned in my butterfly vivarium al fout the same time that $I$ olsserved the specimens in the garden; and among those which came out in confinement many were remarkably small as well as pale. One of these is represented at Figure 3.

The underside of $V$. polychloros (No. 2) forms a fine contrast in tone of colour and in its very different kind of markings to those of the uprex surface. The fine waved strealing of dark brown and l)lack, on the gray, ochreous, or dirkes: brown ground is very striling; and the 
effect is heightened hy a few light specks, especially the one on the middle of the dark part of the hind wing.

The Caterpillar (No.4) is very handsome, and with its curiously brancled spines exhihits the characters of a true $I^{r}$ ancses. It feeds exclusively on Elm, and is searcely ever found where those trees do not abound. In the Plate this Caterpillar has been inalvertently represented upon the nettle.

The Chrysalis (No.5) resembles those of the other Vanesse? in its angularities, and the bright metallic spots with which it is decorated.

Several accidental varieties of this fine insect are occasionally met with, in which two or more of the dark spots are blended into one. These are sought with great avidity by the curious, and I have seen some rery singular examples in different cabinets. Any collector rearing a great number from the Caterpillar state, would be likely to meet with varieties of that kind in some of the specimens.

Reaumur, in his interesting Mémoires, has given some very curious illustrations of the transformations of this insect, which is more common in France than with us. In England it is said to be found chiefly in the southern half of the island; but Mr. Duncan-as quoted by Mr. Westwoor-says it has been talien as far north as Dunkeld. Mr. Stainton gives Huddersficld and York among the more northerly districts in which it has been recently captured. 



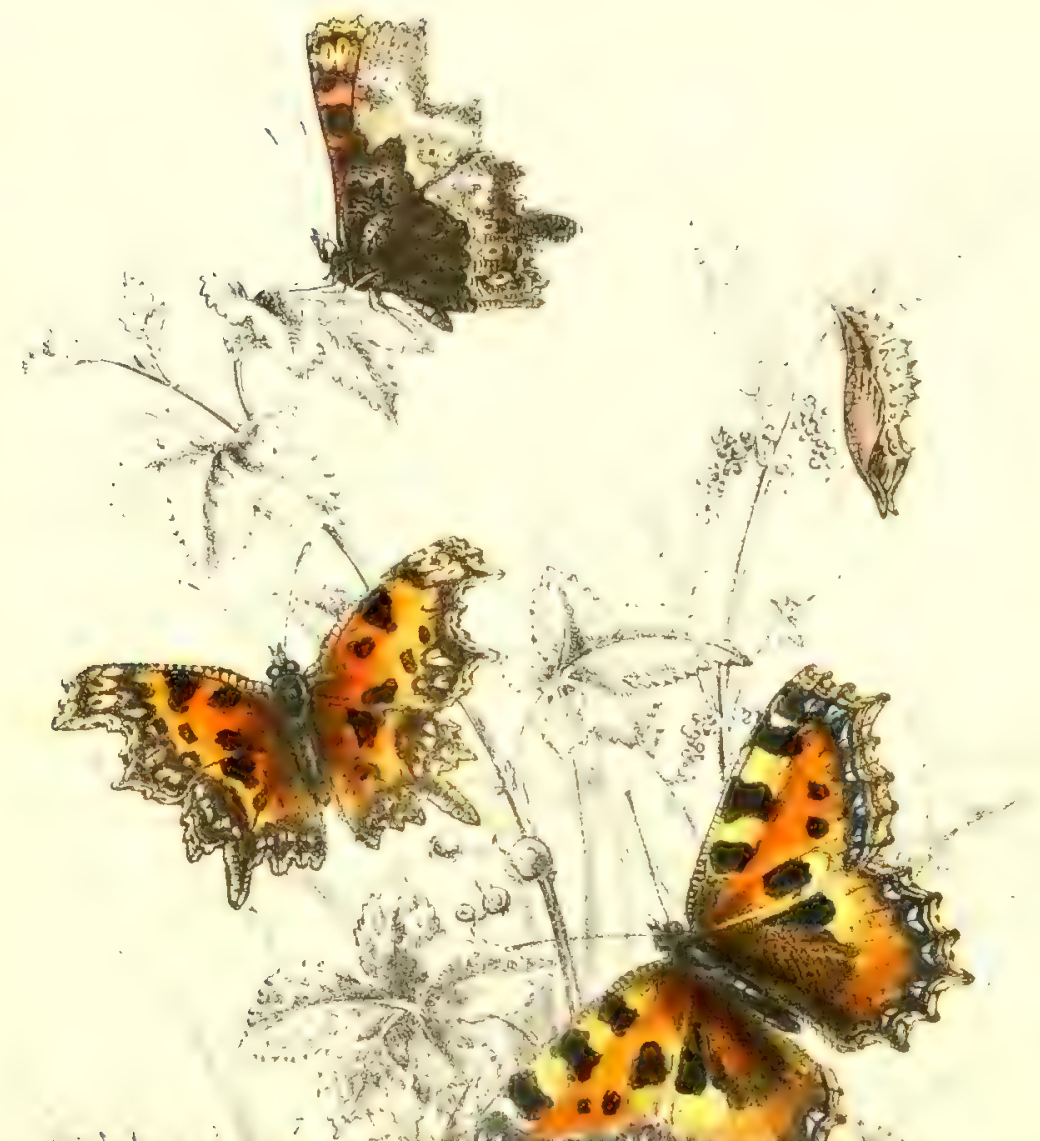

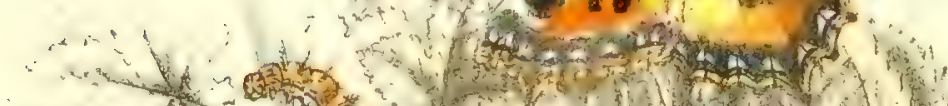

$\therefore-2$.

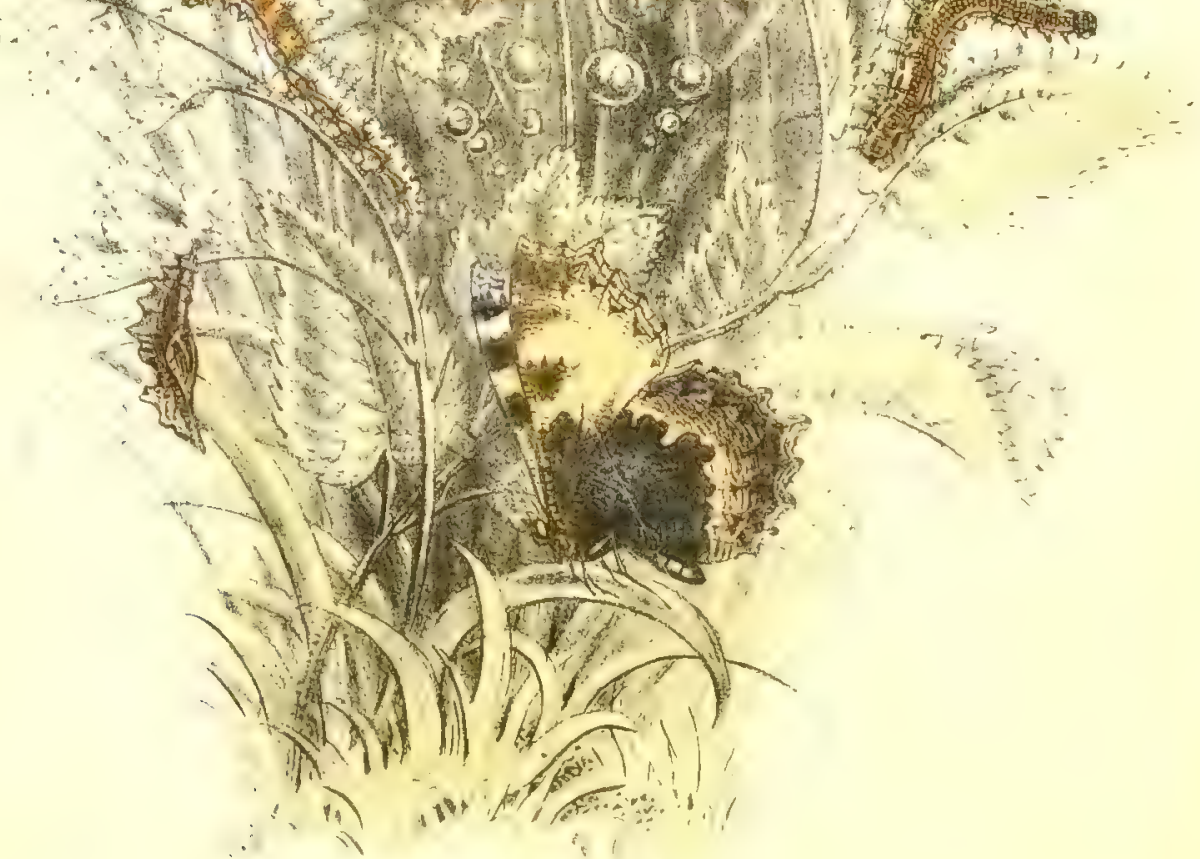




\section{PLATE XV.}

\section{No. 1.-The Silrer. washed Fritillary (Argymis paphia).}

No. 2.-The Female of the Silver-washed Fritillary.

No. 3.-The Under side of the Silver-washed Fritillary.
No. 4.-The Caterpillar of the Silvel-mashed Fritillary.

No. 5.-The Chrysalis of the Silrer-washed Fritillary.

TuE fourth sub-family of the Pupitionider is that of the Argymieli, containing two genera, Argynnis and Militac.

The genus Argynnis. The insects assigned to this genus are distinguished hy the short, compact, and rather spoon-like form of the club of the antenne. The wings are ample, of a rich tamny colour, and marked with dark lines and spot;, the lines upon the veins or nervures being often consideratyly thickened in the males. The fore wings have the margin either rounded or slightly coneare; and the hind wings on the under side are marked with metallic patches or streaks, having the appearance of silver. The front pair of legs are rudimental, and are very hairy, and without joint, in the males; while they are jointed, but nearly free from hairs, in the females. The eyes are large and naked, insteal of heing clothed with hairs, as in some of the $T$ ancisidi. The Caterpillars are spiny; and nearly all the species feed on clifferent linds of the Violet, in woods. The Chrysalis is suspended by the tail, like those of the Vinessidi.

Argynnis paphia (the Silver-washed Fritillary, No. 1). This fine and very remarkable insect, which is the largest of British Fritillaries, is by no means generally common; but in favourable localities, it often appears in some abundance. During a walling tour in Cornwall in the year 1857, I was delighted with a sight of it in some plenty in several localities.

The male insect (No. 1) is of a much brighter colour than the female; and the four principal nervures nearest to the posterior edge of the fore wings are raised and thickened in a singular manner, as expressed in the representation.

The female (No. 2) is, as above stated, of a much less brilliant colour; and there is no thickening of the nervures of the anterior wings: the dark spots are, howerer, larger aml more regularly furmed, and the cluls at the extremities of the antenna are often Iarger than in the male.

The under side (No. 3) exhibits the beantiful strealings of silvery lines across the lind wings, by which this species is distinguished.

The Caterpillar (No.4) is very richly marked with yellow and brown stripes; and the spines nearest the head often project forward like horns, as shown in the representation. It feeds in preference on the common scentless Viulet, Tiule cunine; and the perfect insect aluears in July.

The Chrysalis (No.5) is of a light grayish brown, sometimes with indistinct yellow spots along the back; and the tubereles exhibit the metallie effect of gold described in the Tuncsidi.

Hermaphrodite specimens of this insect occur, in which the individuals have the wings of the male on one side and those of the female on the other. There are also some curious 
rarietics, espucially of the female, in which the ground colour of the wings is nearly gray. or rather a brownish kind of slate colour, varied by a few marks nearly white. These specimens were thought to be the females of a distinct species, till a specimen was captured, in which the wings on one side were of the usual colour, while those on the other side were of the brownish slate colour above described.

The insect has become more rare than formerly. It is, lowerer, still pretty generally distributed in the woods in the South. It lias also been recently captured at Huddersfield, and in some plenty in the neighbourhoods of Scarborough and York. I saw this beautiful species for the first time on the Continent in the Forest of Fontainebleau, where, happening to be just in the season, I found it very abundant. The specimens then captured were precisely identical with specimens afterwards taken in England. 



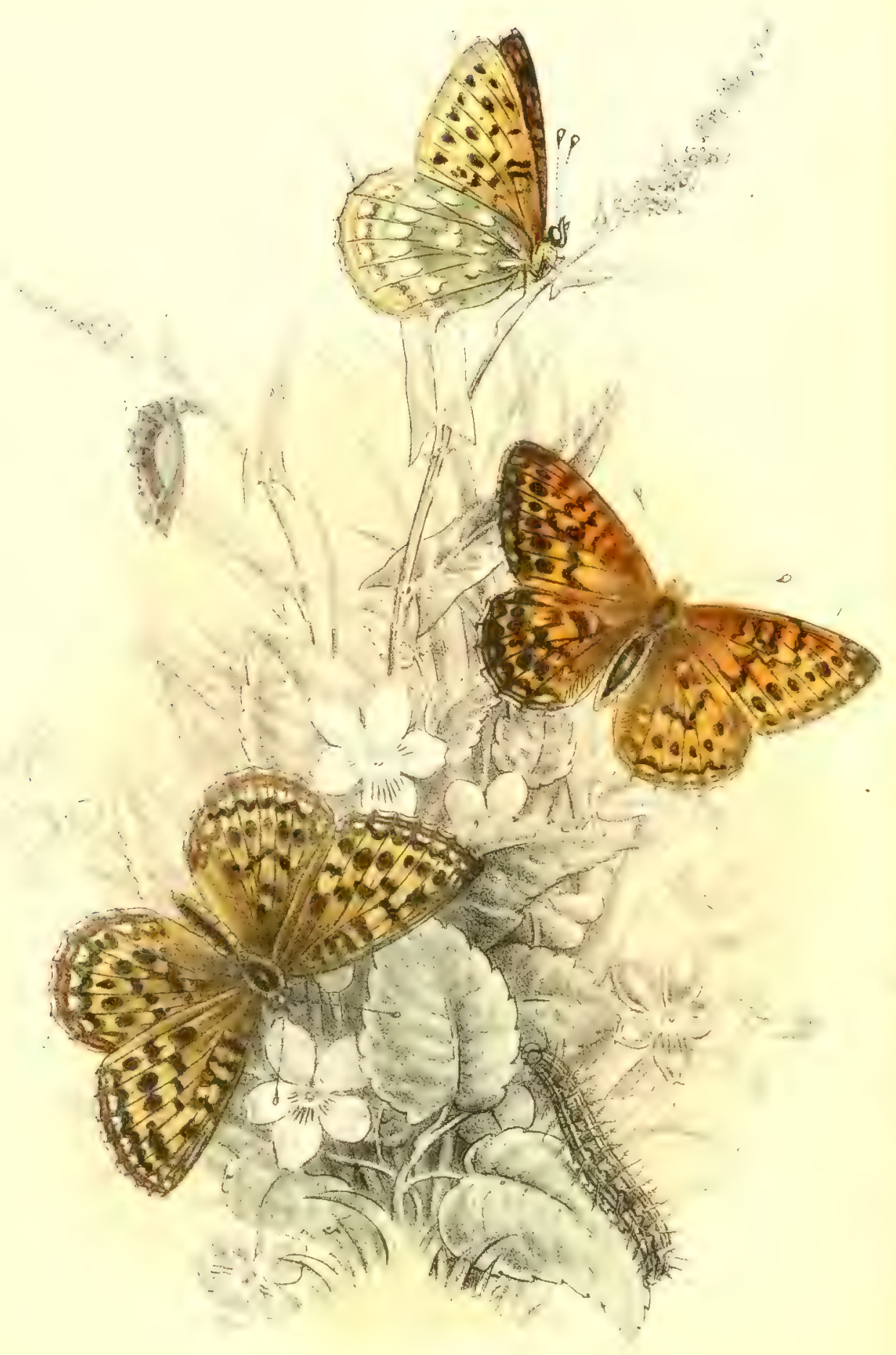




\section{PLATE XIV.}

No. 1. - The Small Tortoise-shell Butterfly (Tanessa Uricice).

No. 2.-The Underside of the Small Tortoise-shell Butterfly.

No. 3.-The Caterpillar of the Small Tortoise-shell Butterfly.
No.4.-The Chrysalis of the Small Tortoise-shell
Butterfy.

No. 5.-The Comma Butterfly (Grapta C-album).

No. 6.-The Under side of the Comma Butterfly.

No. 7.-The Caterpillar of the Comma Butterfly.

No. 8. The Chrysalis of the Comma Butterly.

VANEssa URTIC. (the Small Tortoise-she1l, No. 1). This hrightly-market specie's is sometimes distinguished as the Nettle Tortoise-shell, in allusion to the plant which furnishes the food of the Caterpillar, and in contradistinction to $T$. polychloros, which in a similar manner is often termed the Elm Tortuise-shell. It is much more common than $V^{r}$. $I^{\text {milychlomes; }}$ indect it may be said to be common everywhere. Its sparkling colours, red, white, and yellow, with teselations of blue, make a charming appearance in our gardens as early as the first sunny days of February, and sometimes even earlier. Limneus has called these beantiful insects on their first appearance at this early season, "deceptive heralds of the spring $; "$ for on the recurrence of cold weather they again take to their retreats where they have passed the winter in a sumidormant state; and are seen no more till the next burst of fine weather. In the south of Europe, however, they remain on the wing throughout the mild winter of that more genial climate. This insect is distributed in every part of the British Isles, eren to the extreme north of Scotland, where it is popularly linown as the Devil's, or Witches' Butterfly. The undersile, shown at No. 2, slightly resembles the underside of $Y$. pulyhinos; hut the fore wings hare a larger space of a pale ochreous tone, by which they may be easily distinguished. This pretty insect varies considerably in its markings; specimens occurring sumetimes in which the two mper patches of black at the front edge of the fore wings are joined while the two small round spots behind them are entirely absent. In this curious variety the dark portion of the lind wings extend nearly to the edge, the light red band and the dark borler with the blue seallops being absorbed in it. There are also extremely small rarieties, which are often more lrightly colourect than the larger specimens. The Caterpillar, No. 3, feeds on the common nettle, and appears in the beginning of June, and again in August; the perfect insect appears in July and September; some of the last brood survive the winter, as stated above. The Clnrysalis is represented at No. 4.

The genus Gropte. This genus contains only a single Britislo species, separated from luncssa principally on account of the deep indentation of the margins of the wings, and some slight anatomical distinctions in the Caterpillar. The Chrysalis exhilits deep inclentations in its form, which accord in character with those of the perfect insect, and serve to distinguish it from those of the Venesse, which in other respects it resembles, and is suspended by the tail in a similar manner.

Gropte C-album (the Comma, No. 5). This pretty species is becoming much more searce than formerly. Our elder Entomologists describe it as abumlant near Londun, anel many of 
our living collectors, as Mr. Stainton informs us, recollect taking it frequently, though it is now very rarely seen. The form of the wings, which is remarkable in this species, varies much in different specimens. In some the large concavity near the front of the fringed margin of the fore wings is so deep as to form more than half a circle, while in others it is much less conspicuous. The specimen represented in the mmexed Plate is a medium one. The under side (No. G) presents (as in the closely allied genus Vunessie) an extraordinary contrast to the upper. It is beautifully marked and variegated with different shades of gray, olive, and black; exlibiting near the centre a peculiar white mark, as of a capital $\mathrm{C}$ traced with a delicate pencil in white paint, from which this pretty species takes its name. On the opposite wing this mark is necessarily curved in the opposite direction, which carses it to resemble the figure of a commu, from which the popular name the Comma Butterfly, or the White Comma, has arisen.

The Caterpillar (No. 7) presents one rather remarkable peculiarity, which distinguishes it from the Caterpillars of all the British species of $T^{\top}$ unesse. This peculiarity consists in the colouring of the back, which is of a bright orange colour on the five segments next the head, and white on all the rest. The spines which issue from every segment except the one next the head, are of the same character as those of the larve of $I$. Io, $V$. urtice. The head, which is raised at the sides into two remarkable tubercles, is bristly, as are the spines. This pretty Caterpillar, which is not gregarious, feeds on various trees and herbaceous plants, among which the Currant appears to be preferred: but it is found on Elm, Honeysuckle, and Willow, and also on the Hop, the Nettle, \&c.

The Chrysalis (No. 8) raries in colour from flesh-colour to brown, and it is ormamented when first formed by gold spots, like those of the Vuncssce, which disappear as the skin becomes dry. This insect, according to Harris, remains in the Chrysalis state about fourteen days, and he states also that there are two broods each season, the latter brood being of a paler colour than the earlier one, a peculiarity which accords with my own observations on the late broods of $V$. polychloros. This insect hybemates like $V$. untice, specimens being seen occasionally on the very first fine days of early spring. Formerly it was said to be taken in all parts of England, and north of the Tweed, as far as Fifeshire; but according to the latest entomological records, it is no longer found either near London, or in Scotland. 


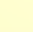




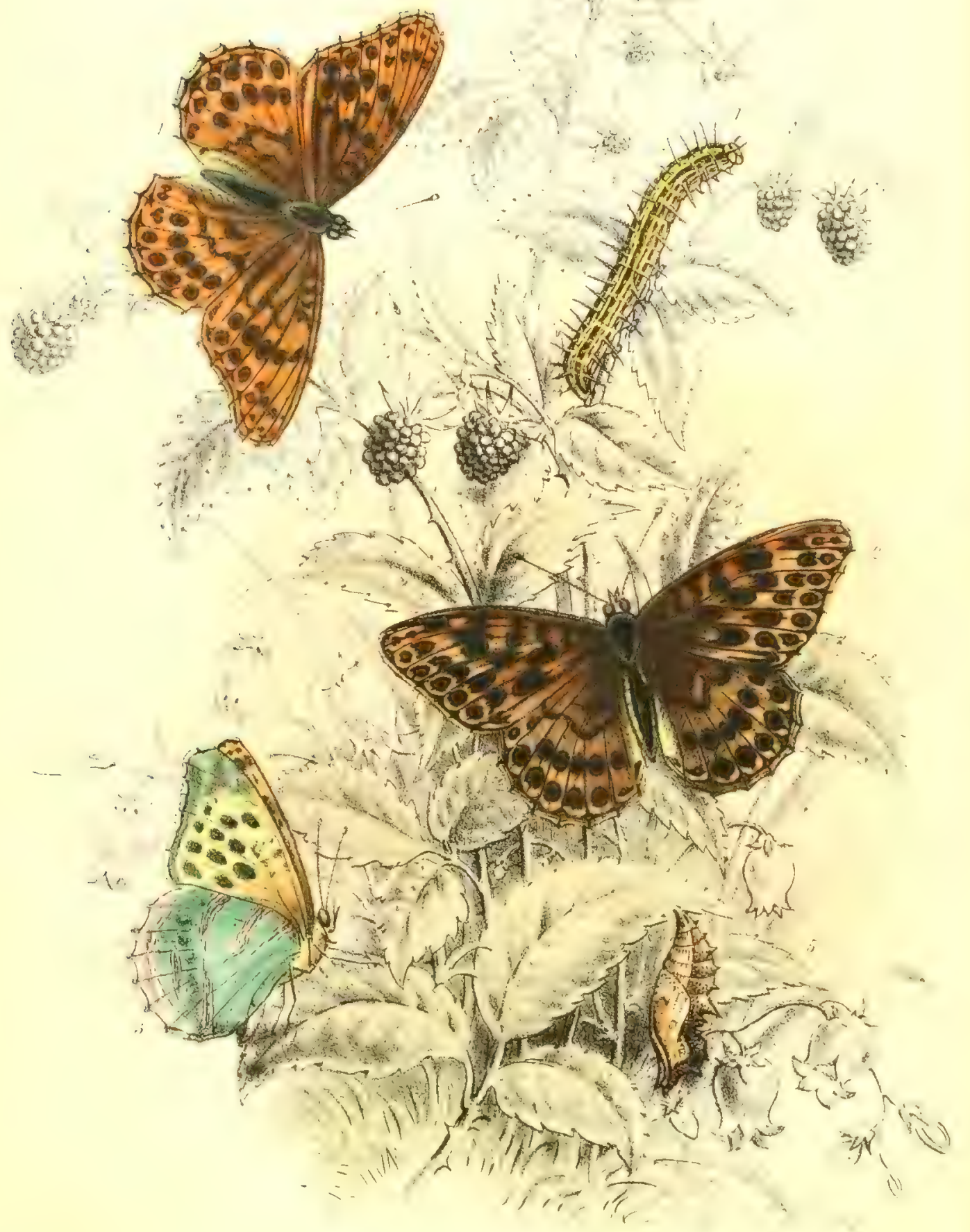




\section{PLATE XVI.}

No. 1. The Dark Green Fritillary Butterds (Argynnis Aglaia).

No. 2.-The Dark Green Fritillary Butterfly (the Female).

No. 3.-The Dark Green Fritillary Butterty (showing the under side).
To. 1.-Tho Caterpillar of the Dark Green Fritillary Butterily.

Fio. 5.-The Chrysalis of the Dark Green Fritillary Butterily.

ARGymis AGLAIA (the Dark Green Fritillary) receives its popular name from the rich green tones which rary the colouring of the hime wings on the minter siele. In this green tinting of the under surface of the hind wings it resembles Argymis Paphic (the Silver-washed Fritillary), but the silvery markings are of a very different character. Instead of being washy streaks they form distinct and sharply defined patches, symmetrically disposed between the veins or nervures. These silvery markings, as they are generally lescribed, have, in fact, more of the pearl-like than a metallic gloss, and might be very closely imitated in a drawing by the substance prepared from the seales of a peculiar fish, which is used in the manufacture of imitative pearl beads. The red-brown of the upper surface of the wings is much brighter in the males than the females, as in the last described genus. The males have also the veins at the back of the fore wings thickened as in A. Paphiu, but much more slightly; and the under surface of the hind mings also exhibits a feature not found in the female insect; this consists of a row of eye-like spots between the two outer rows of pearly patches. The representation, No. 3, showing the under side, was drawn from a male specimen, as will be observel by the presence of the series of spots alluded to.

The female, showing the upper surfice of the wings, is represented at No. 2, in which the cooler tone of the colouring is very conspicuous.

The Caterpillar (No. 4) apmears at the 'met of May and Jume, and is ganerally formd teeding on the Dog Violet (Viola canina).

The perfect insect quits the Chrysalis in July and August. It is common everywhere, especially on heaths and in woods. Among places cited for its recent capture in great abundance, Leicester and Brighton are especially recorded.

There are several very distinct varieties of this handsome insect; in the one formerly known as Argymis Curlotta, some of the black markings on the upper surface of the wings are joined so as to produce a much more strongly marlzed appearance, and several of the pearly spots beneath are connected in a similar manner. Tarieties of this description have oceurred, in which the joining of the dark markings of the upper surface is so general that the wings present the

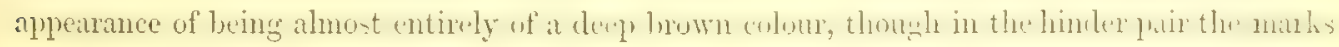
are generally much more separate and distinct. This variety has occurred near Ipswich and Bimingham. A rery pale hufr rariety is also occasionally fumbl, which generilly has the - puts 
and other markings of a somewhat darker tone of the same colour. This is a very elegant variety, and much sought by collectors. It is extremely rare.

In the pearlmarked species of the Fritillary Butterflies, the collector should always display some of his specimens with the umder side nppermost, as heing, in fact, more beautiful than the upper surface. If space, and the lind of cabinet permitted, it would be as well also to place at least one specimen sitting at rest, with the wings raised, in order to show one of the most usual natural positions of the insect. A careful drawing of the Caterpillar and C'hrysalis might also accompany the specimens of the perfect insect, which would lend adlitional interest and completeness to the collection. 



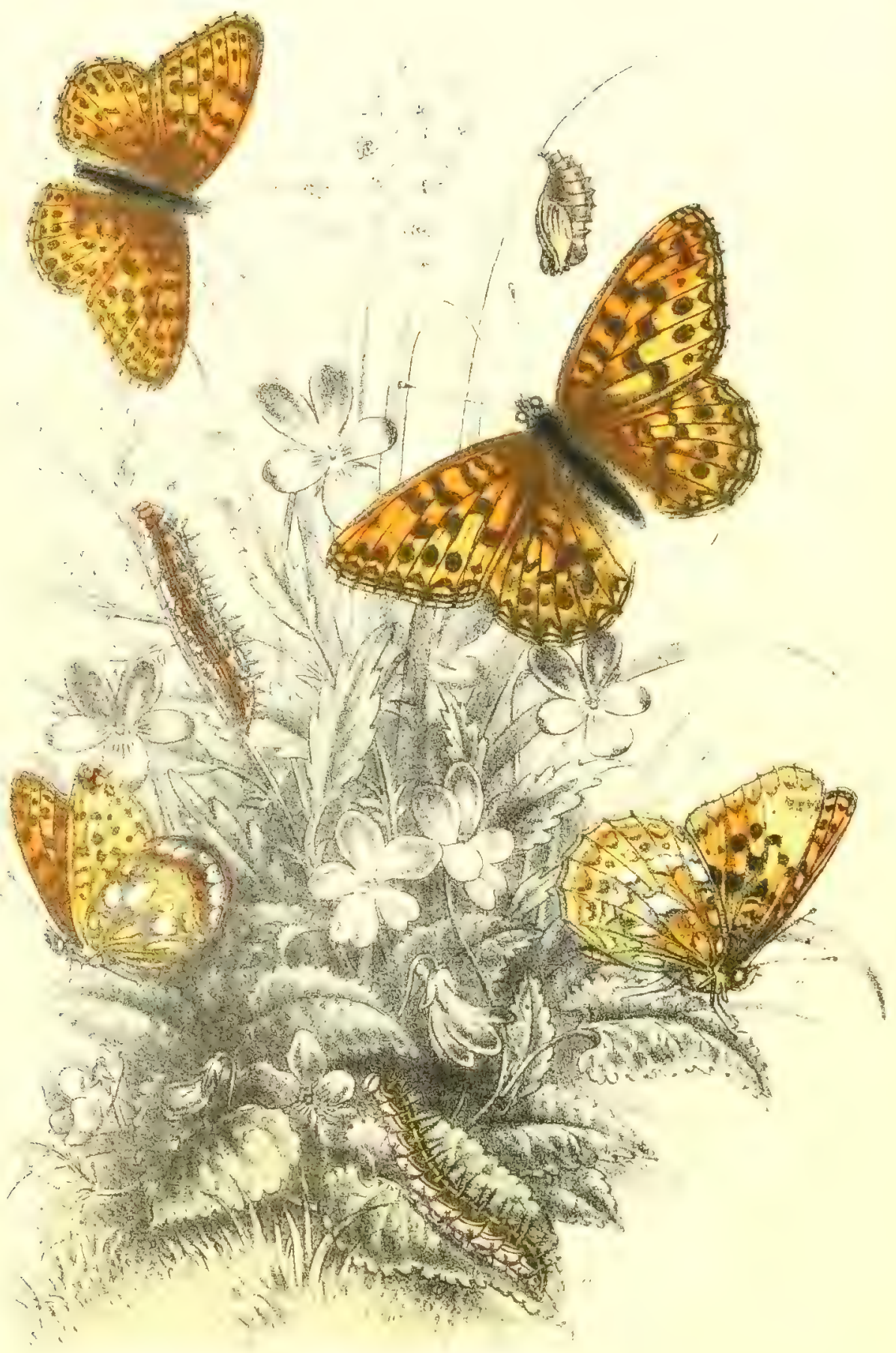




\section{PLATE XVII.}

No. 1. The High-brown Fritillary Butterdy (Argyn. nis Adippe).

No. 2.-The High-bromn Fritillary Butterfly (show. ing the uncler side).

No. 3.-The Caterpillar of the High-brown Fritillary Butterfly.

No.4.-The Queen of Spain Fritillary Butterfly (Argynnis Lathonia).
No.5.-The Queen of Spain Fritillary Butterly (shorving the under side).

No.6.-The Caterpillan of the Queen of Spain Fritillary Butterfly.

No. 7.-The Chrysalis of the Queen of Spain Fritillary Butterfly.

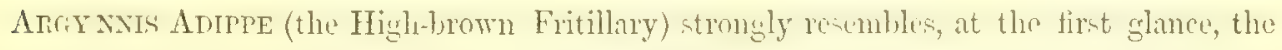
last described species, $A$. Aglaia, but a closer examination enables the observer to detect the more angular character of the black markings. The colour also is different, being of a moro orange tawny tone, which is the same in both sexes; the female being, however, rather paler. and larger in size, while the male is distinguished by thickening of the three posterior veins of the front wings. On the under side (No.2), it may be distinguished at once from Aglaia by the absence of the rich green from the lind wings, which are only varied with tones of buff and brom, and nearly alike in both sexes.

The Caterpillar (No. 3) is, when young, red undernenth, but in its later stages assumes an olive green colour. It feeds on the Heartsease and Violet, on the foliage of which it should be sought in May and early in June.

The Chrysalis is reddish brown with silver specks, and the perfect insect appears in June and July, in woods, and also on heaths. It is much less common than A. Aglaia, but has been taken recently in some abundance at Lyndhurst, at York, and in other northern districts, though it was formerly considered to be almost exclusively confined to the southern counties, where, in fact, it is still found more generally distributed than in the north. There are varieties, as in the preceding species, in which the black marlings run into each other, giving the wings a darker appearance.

Argynnis Lathonia (the Queen of Spain Fritillary, No. 4) is by far the rarest of our large

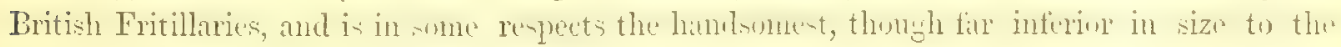
three species previously described.

The males may be distingui-hed hy the dilation of the postering nervures of the front wings; in other respects the colouring and markings are alike, or very nearly so, in both scxes.

The under side (shown at No. 5) has the pearly patches more symmetrically distributed than in any of the other species, and of a more brilliant character, both as to their gloss and their more metallic appearance. In some Continental specimens which I have seen, these markings are enlarged so as to cover the whole of the surface of the hind wings, which thus assume the aspect of a burnished plate of silver, marked at intervals with dark streaks formed by the nervires.

The Caterpillar feeds on the Borage, and also on Heartsease and Violet. There are said to be two broods, one most probably appearing in April or early in May, the other in July. 
The Chrysalis is dark brown, with one large metallic mark of a silvery colour, and several

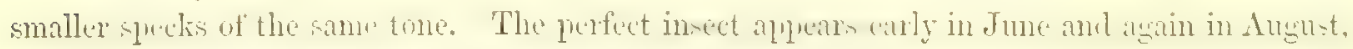
but is very rare in England, though so common on the Contiment as to possess no value in the cyes of ordinary collectors. I recollect taking several specimens in a few minutes while walking up one of the steep portions of the roal over the Mlount Cenis by the side of the Diligence. According to Mr. Stainton, the places in England most recently cited as localities in which it

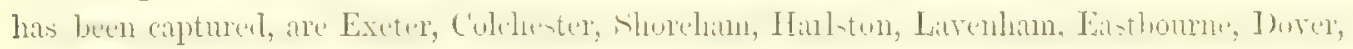
Bristol, and Peterborough.

This beautiful insect should be sought in May or the beginning of June, and again in August. Its favourite launts are at the borders of woods, on sunny banks, where if seen it may be easily captured, as it is so fond of basking in the sun when settled, that the collector may approach within a secure distance for the use of the net, without alarming it. Very few speci-

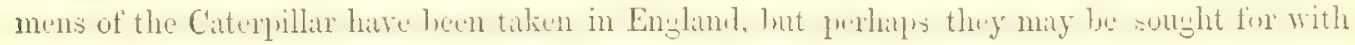
success if the proper season and proper situations be selected. 



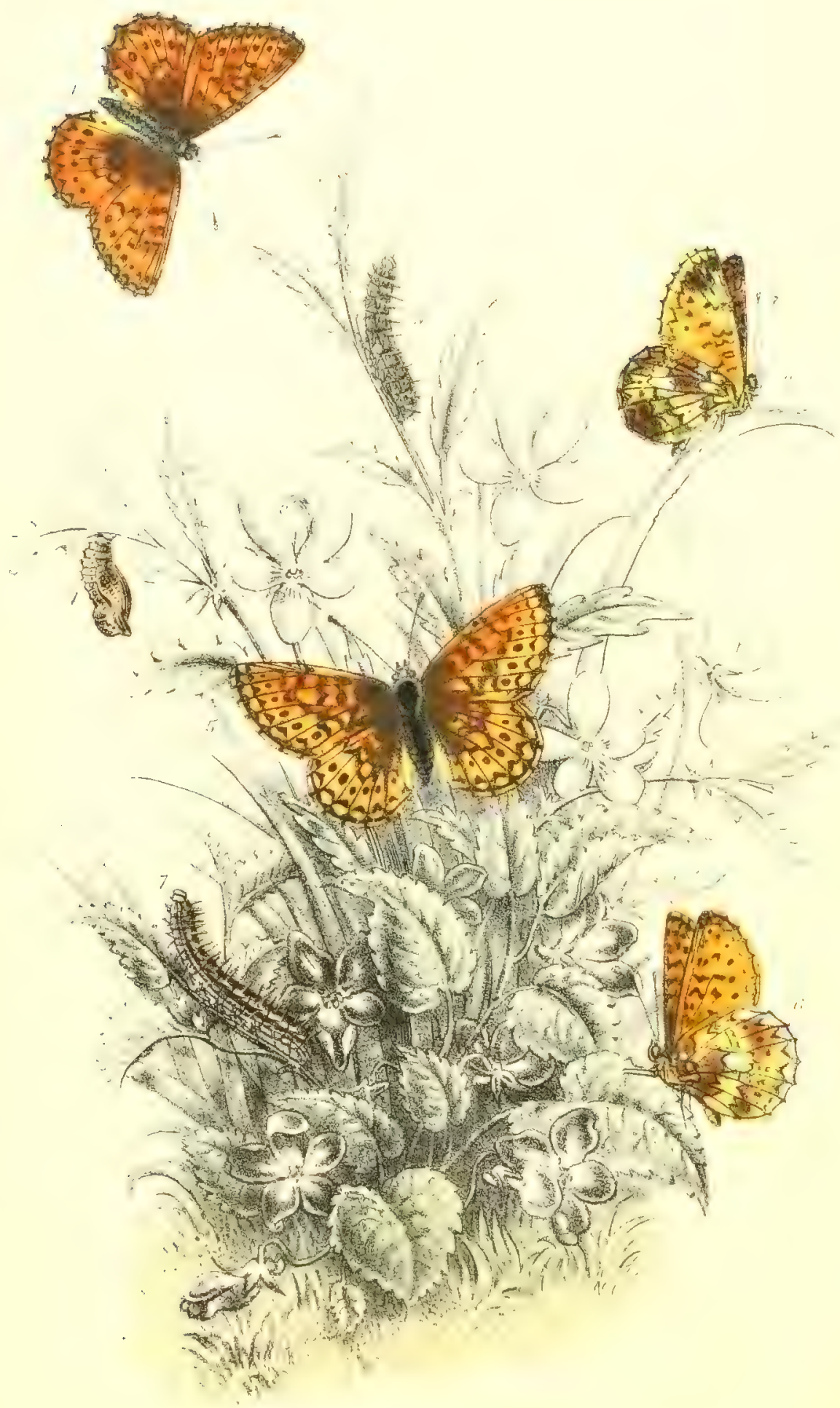




\section{PIATE XVIII.}

No. 1. - The Suall Pearl-bordered Fritillary Butterfly (Argynnis Selene).

No. 2.-The Under side of the Small Pearl-bordered Fritillary Butterlly.

No. 3.-The Caterpillar of the Small Pearl-bordered Fritillary Butterfy.

No. 4.-The Chrysalis of the Small Perrl-bordered Fritillary Butterfly.
No.5.-The Pearl-bordered Fritillary Butterny (Argynnis Euphrosyne).

No. 6.-The Under sille of the Pearl-bortered Fritillary Butterfly.

No. 7. The Caterpillar of the PearI-bordered Fritil. lary Buttertly.

THE two species of Argymis represented in this Plate form a very distinct section in the genus, being both considerably smaller than any of the other species. They were formerly placed in the genus Neliteu, as according in size and general appearance with the species still retained in that genus; but their metallic markings (entirely absent in the species still regarded as belonging to IIctitcea) and other characteristic distinctions, lave caused their being located in their present pasition.

Argymis Selene (the Small Pearl-bordered Fritillary, No. 1). This species is common, though rather local. It is said by some entomologists to be double-brooded, being occasionally captured both in May and July, while Mr. Nerrman states that it appears fifteen days later than A. Euphrosyne, and continues till the end of July, after which it never re-appenss. Mr. Dale, however, describes it as double-brooded, and states that the two broods differ, the second being always slightly different in colour to the first.

The hind wings are generally marlsed as shown at No. 2, but varieties occur in which the under side of the front wings is entirely pale buff, with the black marks rery slight and delicate, and the hind wings of a greenish tone, with slender rays of the metallic claracter running down between the veins, beyond which are a few metallic spots.

The Caterpillar (No. 3) should be sought at the end of April or in May, when, in farourable situations, it will be found feeding upon the Viola ceniuu, the common Dog Violet.

The perfect insect quits the Chrysalis (No.4) at the end of May or early in June, liut there may be, as stated, another and a later brood. It is most common in woods and thickets, especially in the South of England. It has been taken nenr Teignmouth in great numbers. It

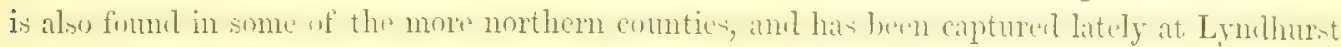
in some abundance.

Several varieties are occasionally found, and the species described in English cabinets as Melitce Dia, is probably one of the varieties of this pretty insect. Mr. Stephens has described a singular variety in which the ground colour of the upper surface of the wings is nearly white.

Argynnis Euphrosyne (the Pearl-bordered Fritillary, No. 5) is generally larger than the last described species, and of lighter colour. The distribution of the metallic markings on the under side of the hind wings (No, 6) is also different, though of similar character, being generally less distinct. These markings of the under side vary, however, very considerably.

The Caterpillar (No. 7) feeds on various kinds of Violet and Heartsease, and there are two broods in the season, the first being found in April and the second in July. 
The perfect insect of the first brood generally leaves the Chrysalis in May, and the second in August. It is a very common species, being found in all parts of the country, even far

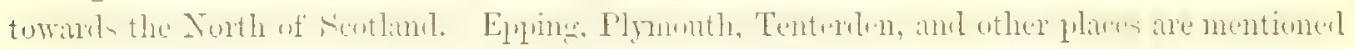
as localities in which it has been recently taken in alundance.

There are varieties in which the dark marks on the upper side of the wings are nearly united, giving the whole surfice a rich deep mottled brown appearance.

Consilerable additional interest might be gained in forming a collection of the British Fritillaries, by the study, at the same time, of some of their foreign relatives, many of the exotic species being extremely beantiful. The study of foreign genera, at the same time with the British, also gives the student a better general idea of classification and clearer notions upon the scientific location of our native species; the foreign linds frequently forming links whick exhibit, in an instructive manner, the methods upon which the classification of Lepidopterous insects has been pursued. 



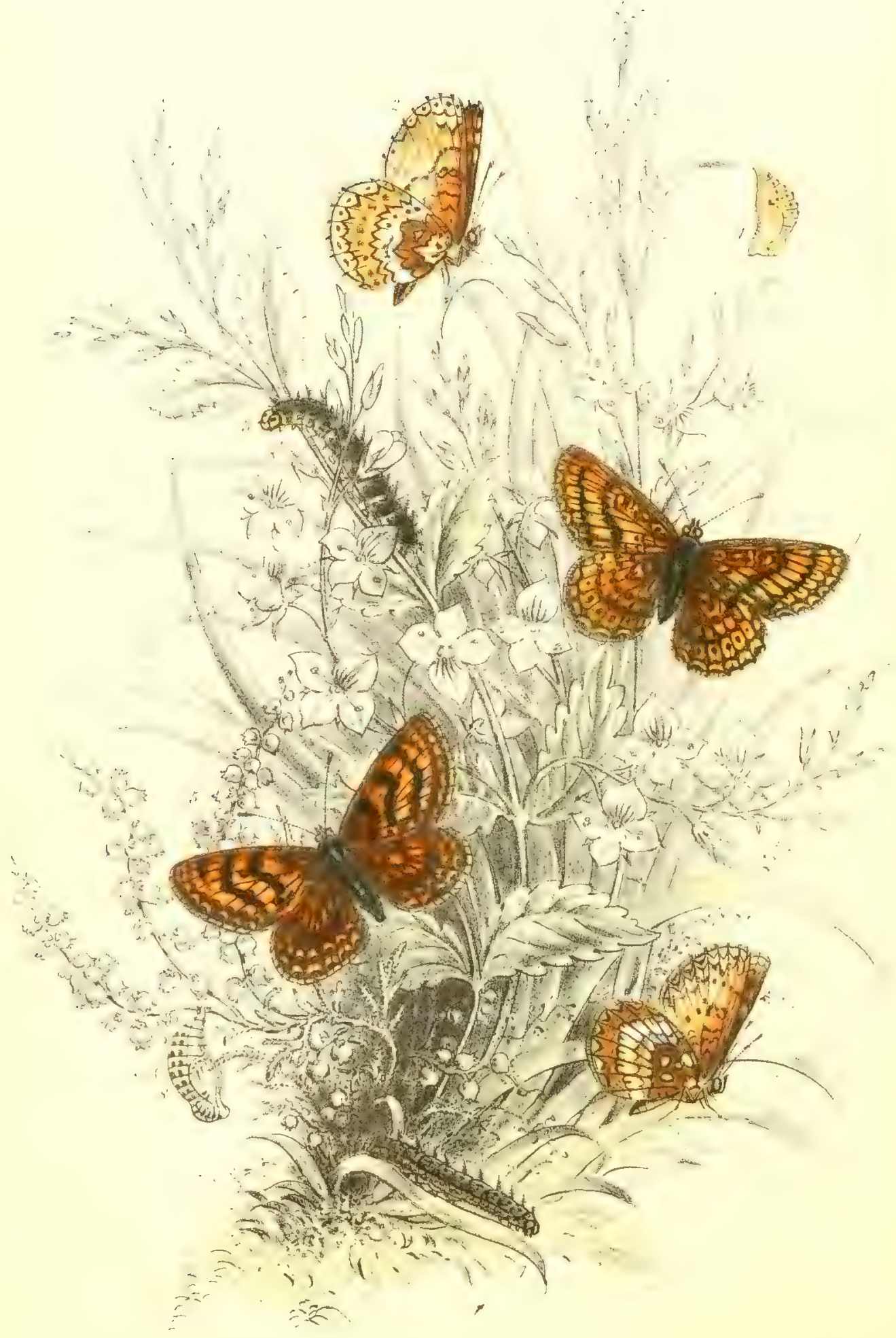




\section{PLATE XIX.}

No. 1. The Glanville Fritillary Butterfly (Melitax Cinxia).

No. 2.-The Under side of the Glanville Fritillary Butterfly.

No. 3. -The Caterpillar of the Glanville Fritillary Butterfly.

No. 4,-The Chrysalis of the Glaurille Fritillary Butterfly.
No. 5.-The Heath Fritillary Butterfly (Melitca Athalia).

No. 6.-The Under side of the Heath Fritillary Butterfily.

No. 7.-The Caterpillar of the Heath Fritillary But= terifly.

No. 8.-The Chrysalis of the Heath Eritillary But. terfly.

THE genus IIelited. The insects contained in this genus, according to the system I am

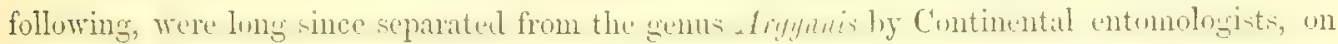
account of the absence of the pearly or silvery patches from the under surface of the wings. It is but recently, however, that this arrangement has been followed in English collections, thongh such an arrangement, with other molifications in the dacification of the Fritillaries, was suggented hy Mr. Westwool in my formen work, pulbinherl in 1811. Of the three species now assigned to the genus, the following are the chef charateristics. The antemnit are of moderate length, and have the club of a rather chongated form. The palpi are rathere long, point-

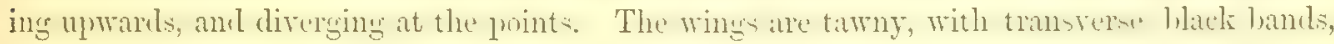
and black streaks down the nervures. The continuous black bands may be cited as a character which distinguishes the species of small fritillanies still retaind in the ginuts ilclitere from those tran ferred to Arymnir: the last having the bands broken up into detached marks or rounded spots. The insects now assigneel to the genus Blelitere are distingatingel moreover by the absence of the silvery maks as before stated, and by a greater degree of correspondence between the marlings of the upper and nether surfaces. The front pair of legs are spurious, or unsuited to walking, in hoth sexes; there of the female having. however, jointml tarsi, while those of the male are without joint in this portion, and much more covered with hair. The

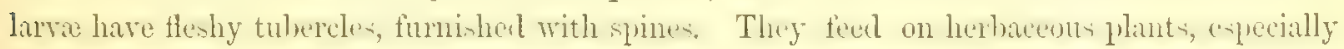
the common Plintain, or the Devil's-lit Scalfions; and are, it is sail, always hatcher in the autum, living through the winter in clusters, protected loy a wer), and attaining their full growth in early spring. The Chrysalis is suspended by the tail.

Meliene Cineres (the Glanville Fritillary, Xo. 1) in the rarent of the three British species, and is extremely local. Where it does oecur, loweres, it is gemerally found rather alumedutly, eppecially in some localities in the Isle of Wight. The Rev. J. F. Dawsin, in a communication to the "Zoologist," has given a very interenting account of the halbits of this pretty insect als he has observed them at Sandown, where, as it would appear from his aceont, they only frequent wild portions of the elitls, in which cultivation does not threaten their hames with unsuitable imovations. The exges are generally depusiten on the leaves of the narrow-leared Plantain in low and protected situations, where the young brood when hateTed pass the winter heneatl the protection of a family awning of silky webbing. In the spring, when the growing caterpillars disperse, they invariably seck the higher gromed, as more sumy and better suited to the develupment of the Chrysalis; which is generally fomed surpended to the lower portions 
of stunted Plantains, or to the under sirle of an angular stone, where they an senerally fomm in pairs. Last season it is stated that but few appeared in that locality, the writer informing us that they have insect foes which clestroy many of the larve; and that even in the perfect state one of the hunting spiders, a large round-bodied species, preys upon this butterfly, lying in wait till the victim alights upon some low plant, and then flarting upon it with unerring aim. I believe that human enemies, in the shape of indefatigable collectors, have also had a share in decrensing the supply; for since the study of Entomology has become a fashionable pursuit, professional collectors have sprung up, who drive a pleasant and profitable trade-hurrying off to any newly discovered locality favourable to some rare species, and not leaving the spot while a single specimen is to be secured. The perfect butterfy appenrs in May, in farourable seasons; but in cold springs the Caterpillars are still feeding at that time, and it is not seen till the middle of June. It is found also at Sandrock, and near Rycle in the Isle of Wight, and at several places in Hampshixe and Devonshire; also at Dover and Birch-Wood in Kent, and at Leamington in Warwickshire; and even as far north as Yorkshire, where it has been taken in more than one locality.

Melitece Athalia (the Heath Fritillary, No. 5). This insect is rare near London, but in other districts it is sometimes abundant; and always much more so than the preceding species. It may be distinguished from MI. Cinxiw by the rather deeper ground colour of the upper surface of the wings, and by the broader but rather more irregular character of the transverse bands. On the under side (No. 6) it differs also by the much stronger colouring of the markings, by the narrower proportion of the exterior brown band of the hind wings, and by the albsence of black and brown spots. The Caterpillar, (No. 7) feeds upon the Plantains, and also upon the common Heath, as represented in the plate. There are many interesting varieties of this insect, especially the very pretty one supposed to be the M. Pyronic of Hübner. This variety has the upper surface of the front wings almost without markings, except a dark border, while the hind wings are entirely black, with a fow tawny dots. On the under side, the light parts are nearly white, with brown markings; the lower half of both pairs of wings being also nearly black, with veins and a few marks of obscure tawny. The Pupilio tesselutu of Petiver, is also considered to be a variety of this species. In this variety the upper surface of the wings is pale, and marked with extreme regularity; the marks having a much more even and tesselated ap-

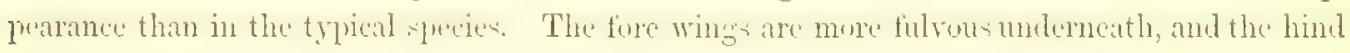
wings entirely straw colour, with black veins, having at the base three large yellow spots bordered with black; also a broad band of deeper straw colour, bordered with black, running across the centre of both wings, \&c. This elegant variety appears to have been pretty constant in Petiver's time, and was found each season in some plenty, in Caen Wood, at Hampstead, whence it was formerly called the Hampstead Bearty.

Several places in the metropolitan counties, and also in Devonshire and Bedfordshire, aro

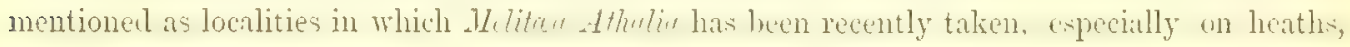
and in open places in wouls. It lias alsu been taken at Tenterden in considerable numbers. 



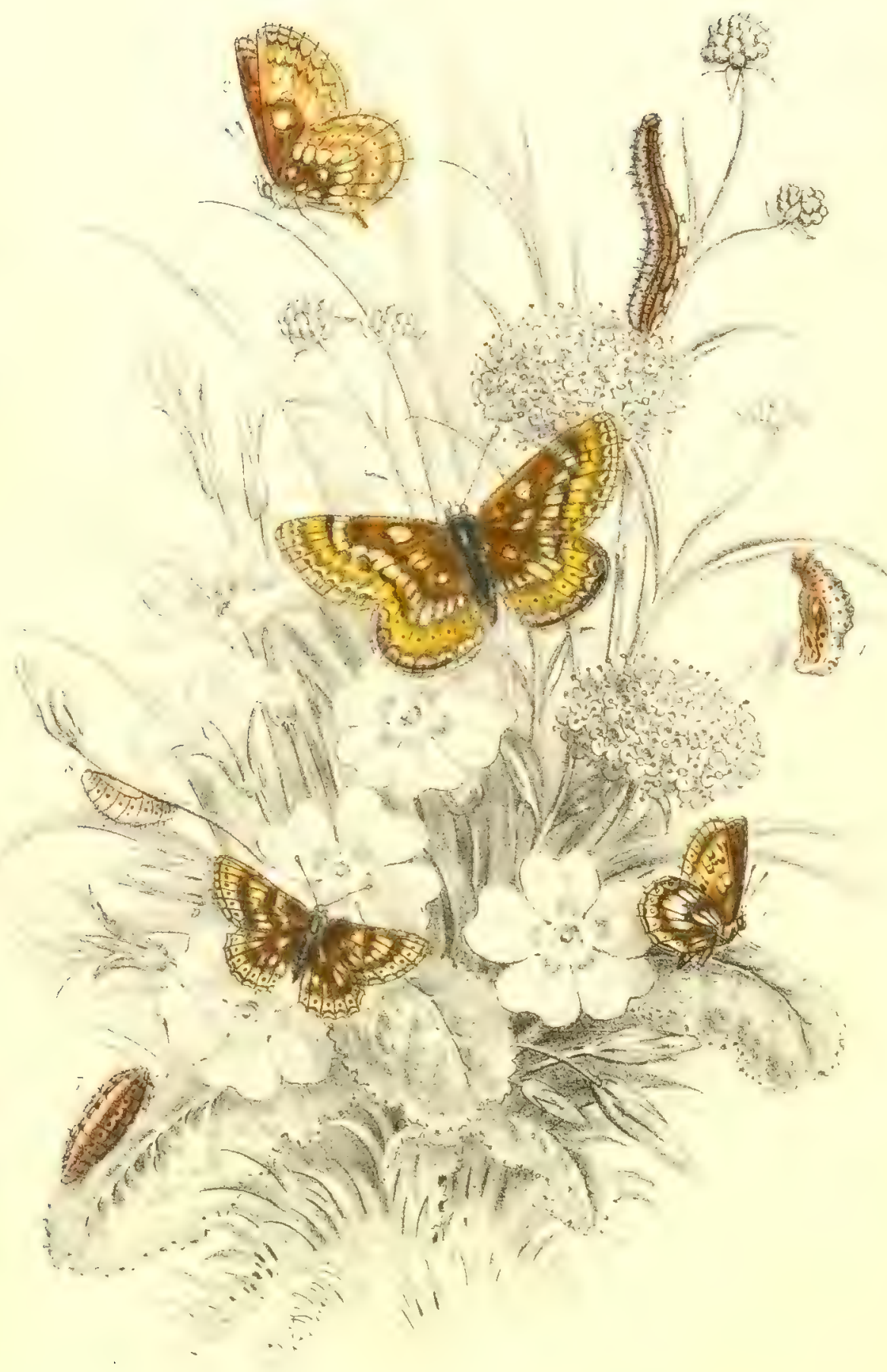




\section{PLATE XX.}

No. 1.-The Greasy Fritillary Butterfly, (Nelitoca Artemis).

No. 2.-The Under side of the Greasy Fritillary Butterfy.

No.3.-The Caterpillas of the Greasy Fritillary Butterfly.

No. 4.-The Chrysalis of the Greasy Fritillary Butterfly.
No. 5.-The Duke of Burgundy Fritillary Butterfy. No. 6.-The Under side of the Duke of Burgundy Fritillary Butterfly.

No. 7.-The Caterpillar of the Duko of Burgundy Fritillary Butterdy.

No.8.-The Chrysalis of the Duke of Burgundy Fritillary Butterfly.

Melitea Artemis (the Greasy Fritillary, No. 1) is perhaps the commonest of the genus, but is nevertheless very local. It is a very distinct species, two irregular bands of palish buf: between the bands of black rendering it distinguishable at a glance from either Cinxic or Athrlic. The under side (No. 2) is very similar to that of Athalia, but may be at once recognised by the paler character of all the markings, and the presence of a regular series of black spots circled with buff (in the broad band near the edge of the hind wings), which are absent in Athalict.

The Caterpillar (No. 3) feeds on the Devil's-bit Scabions, and on both the Plantains. Ac-

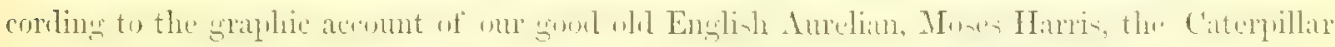
when full grown, draws together two or more blades of grass, fastening them at the top with a web, and suspending itself in the centre beneath; but as I have never seen the Caterpillar or Chrysalis when stannended in this manne', I have merely represented it ats attached by the tail in the usual way.

The Chrysalis (No. 4) is of a pale flexh-colour, prettily ormamented with dark and regularly

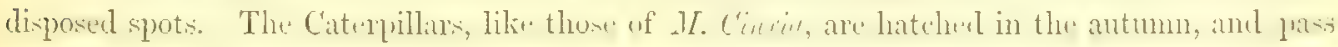
the winter in a similar manner. They become full grown in April, and the perfect butterfly appears in the following May or June. It is generally found in marshy places and has hence been termed by some entomologists the Marsh Fritillary. Specimens of M. Artenis vary considerably in the intensity of their markings, some of the varieties having been mistatien for M. Cinxic. Near Brighton, and also near Bristol, this species has been recently taken in great abundance; and Carlisle, Charnwood Forest, and Weston-super-Nare are also cited by Mr. Stainton as localitie's in which it is often captured, as well as Fork, Winchester, and Irorecenter. Meliter Diu, a closely allien species, was formerly found in our English catalosutes as a native species, on the strength of specinens taken at sutton Park, near Binninghan, and at Alikerly in Cheshire, but it is now omitted. It is the Argynnis Dia of Hübner and Ochsenleimer.

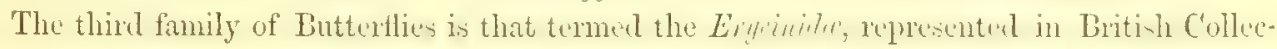

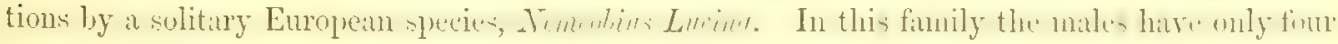
perfect feet, like those of the Argynnidi, but the females have all six feet perfect. The Cater. pillars are oniscifom, like those of the Lygenide, to which fimily, therefore, this genus, in its present position, forms an appropriate link.

The genus Nemeobius has the antennæ slender and the club short; the wings are tawny;

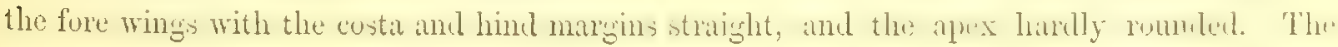


male, as above stated, having only four legs fitted for walking, and the female six. The Caterpillar is onisciform, or woodlouse-shaped. The Chrysalis is attached by the tail, and also secured by a loop romd the middle.

Nemcobius Lucina (the Duke of Burgundy Fritillary, No. 5) is the IItmearis Lucina of Hïbner, but Mr. Stephens's name Nenculizs will be preferred, in consequence of the new and more appropriate location of the insect in its present position by that accomplished entomolo. gist. Mr. Curtis lias quoted the following interesting description of the transformation of this pretty little Butterfly from the clabonate and accurate work of Hübner :- "The eggs are found solitary, or in pairs, on the under sufface of the leaves of Primulu reris, and clutior at the beginuing of summer; they are almost globular, smooth, shining, and pale yellowish green. The Caterpillar feeds on these plants; its heal is roundish, heart-shaped, smootl, shining, and bright fermginous, black only on the mouth and about the eyes: its body is almost oral, but long, depressed, and set with rows of bristly warts; the other parts are set with feathery hairs; on the back, at least from the fourth joint to the tail, there is a black dot on each joint, and on the sides similar but less distinct spots, the colour is pale olive orange; its feet are rusty brown; the spiracula black; the claws and belly whitish. It moves very slowly, rolls itself up when disturbed, and remains in that state a long time. Soon after the middle of summer it becomes a pupa, not only fastening its body by the apex, but also by spinning a cord across its miclde ; in this state it remains until the end of the following spring:" Hiibner, who reared it from the egg, says also that the Caterpillar throws of five skins before it becomes a pupa, and its appearance, at different ages, varies considerably. The larva from which he made lis drawing, and from which my representation (No.5) is taken, he found on a Primula in his own garden. This pretty insect is not uncommon in the south of England, but more rare in the nortl.. At Halton in Buckinghamshire it has recently appeared in great numbers; and Brighton, Oxford, Plymouth, Winchester, and Dursley in Gloucestershire are cited as localities in which it is not unfrequent; while even at York and Lyndlinrst, in the north, persevering collectors have succeeded in taking it in some plenty. 



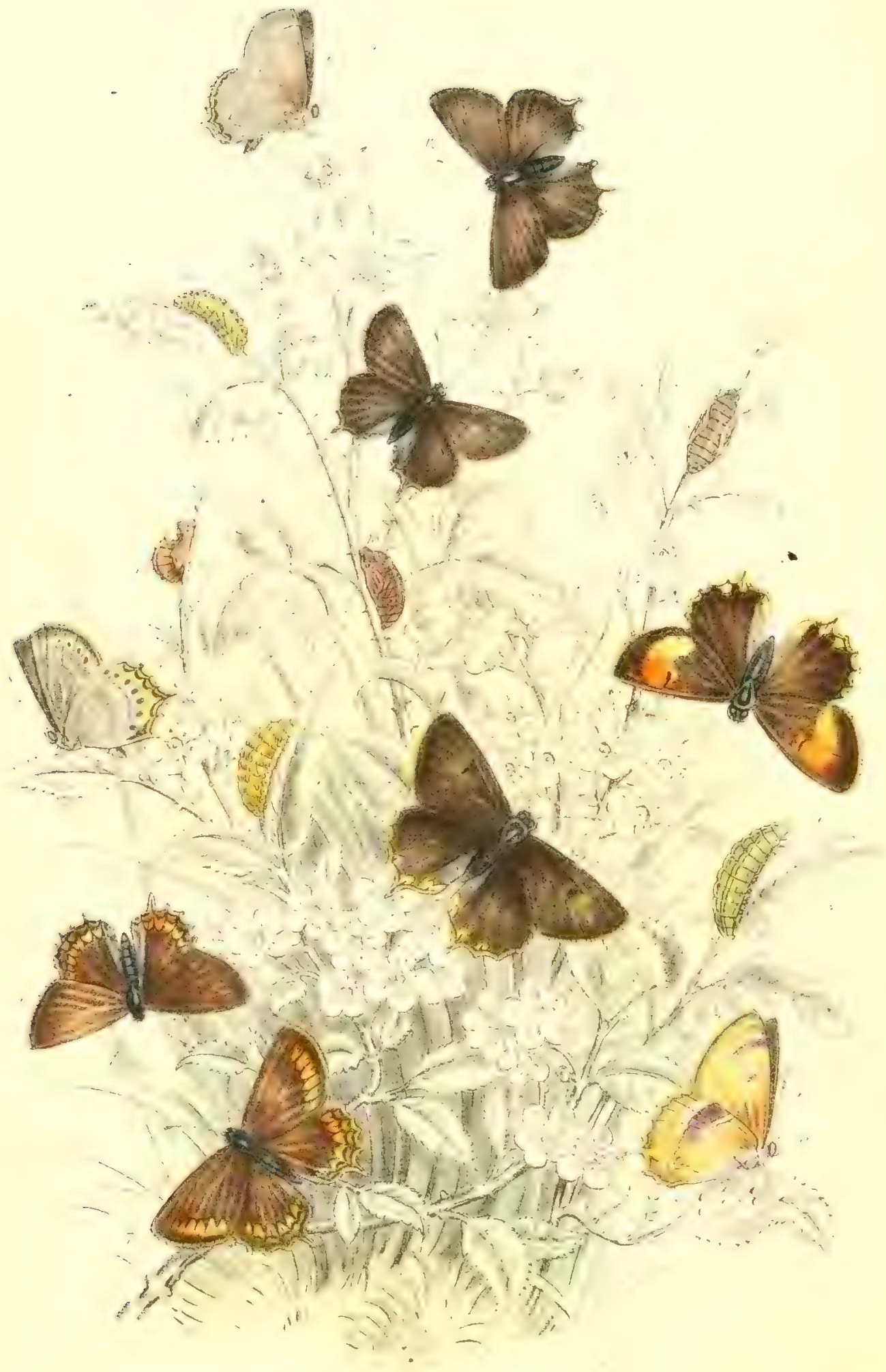




\section{PLATE XXI.}

No. 1.-The Brown Hair-streak Butterfly (Thecla Betule).

No, 2.-The Female of the Brown Hair-streak Butterly.

No. 3.-The Under side of the Brown Hair-streat Butterily.

No. 4.-The Caterpillar of the Brown Hair-streak Butterfly.

No. 5.-The Chrysalis of the Bromn Hair-streak Butterfly.

No. 6.-The Dark Hail-streak Butterfly (Thecta Pruni).

No. 7.-The Female of the Dark Hair-streak Butterily.

No.8.-The Wpder side of the Dark Hairostreak Butterfly.
No, 9.-The Caterpillar of the Dark Frair-streak Butterffy.

No. 10.-The Chrysalis of the Dark Hair-streak Butterfly.

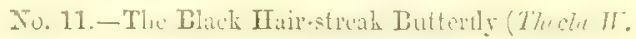
album).

No. 12. - The Female of the Black Hair'streak Butterfly.

No. 13.-The Under side of the Black Hair-streats Butterfly.

No. 14:-The Caterpillar of the Black Hair-strcak Butterfly.

No. 15.-The Clurysalis of the Black Hair-streak Butterfiy.

THE fourth family of the Rhopalocere, or Diumal Lepidoptera, is that of the Lycanide, containing three genera and twenty-one species, being above a fourth of the total number of

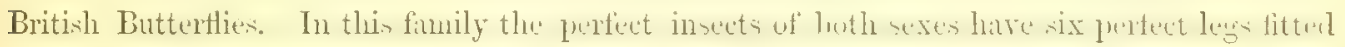
for walking. The larve are short and onisciform. The Chryalis in fistened ly the tail, and also secured by a threal round the midelle. The insects are generally unch smillew than in the preceding families.

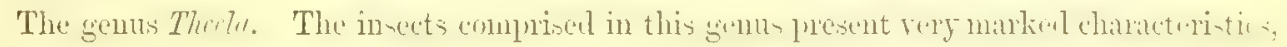
and group very homogeneously together. The hind wings have nearly always a narrow tail.

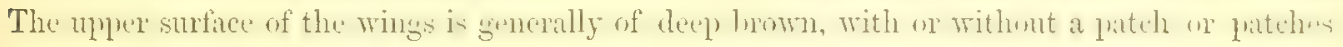

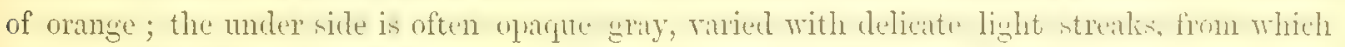

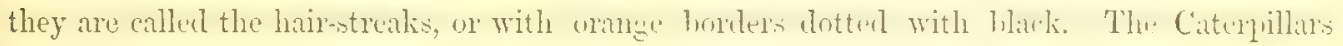
and Chrysalides of all the species accord with the characters assigmed to the family.

Thecla Betula (the Brown Hair-Streak, Nos. 1 to 5) is the largest of the genus. The male (No. 1) is smaller than the female, and the uniform deep brom of the upper surface of the wings is only varied hy a somewhat paler mark adjoining the howt tran-reres black line in the centre of the anterior wings; while the female (No. 2), which is much langer, is di-tingul-nel

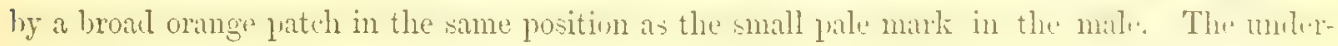
side (No. 3) is the same in both sexes. The Caterpillar (No.4) feeds upon the foliage of the Birch and Blackthorn, \&c., towads the ent of June and hegining of July; the purfect insect appearing in August. It frequents hedgerows, particularly in the southern counties. It is however a local, though far from a rare species. It has been recently taken at Blandford,

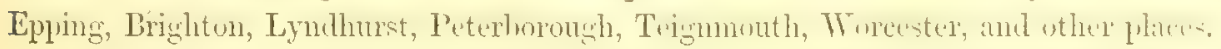

Theck Pruni (the Dark Hair-Streak, Nos. 6 to 10) is smaller than the preceling, and the male is distinguished by an orange border on the hind wings. The female (No. 1) has an additional orange band near the edge of the front wings. The under side (No. T) has the

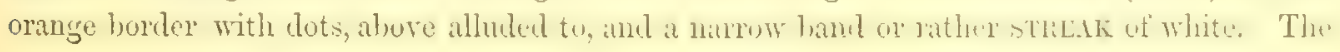


Catepillan (No. 9) fecels on the fuliage of the Plum in May, and the prefect insect appears in July. The Chrysalis (No. 10) is marked with two patches of white, as shown in the illustration. This is, comparatively speaking, a new British species, not having been noticed, and Thecle $W$. album, having been described as T. Pruni, before Mr. F. Stephens detected the error in 1827; previous to that time it had evidently been confused with the other species, from which however it is very distinct. At Monk's Wood, and at Overton Wood, Herts, it is sometimes taken in abundance, but in other localities it is extremely rare.

Thectu $W$. allum (the Black Hair-Streak, sometimes called the W. Hair-Streak, Nos. 11 to 11). This pretty species las the upper surface of the wings entirely of a deep full brown, with the exception of a small pale speck in the front wings of the male. On the underside (No. 13) the white streak forms a strong zigzag towards the posterior angle of the hind wings, from which the specific name is derived. The Caterpillar (No. 14) feeds on the Elm and Blackthorn towards the end of May or begiming of June, and the perfect insect appears in July. This insect, as above remarked, was confused with T. Pruni previous to the remarks of Mr. Stephens on this genus; Villars and other entomologists having described the two species as identical. Previous to its discovery by Mr. Stephens in great abundance, at Ripley, in 18:6, where he captured two hmolred specimens without moving from the spot where he first noticed them, the insect was considered rare. Its appearance there in such vast numbers in that season is one of the curious entomological facts not easily accounted for, and like the strarm of Tunessi Antiopa at Camberwell, and the occasional swarms of Picris Brassica, it still puzzles our entomologists. It has been recently taken at Brightun, Epping, Petuljorungh, Yurk, and other places, but sparingly. 



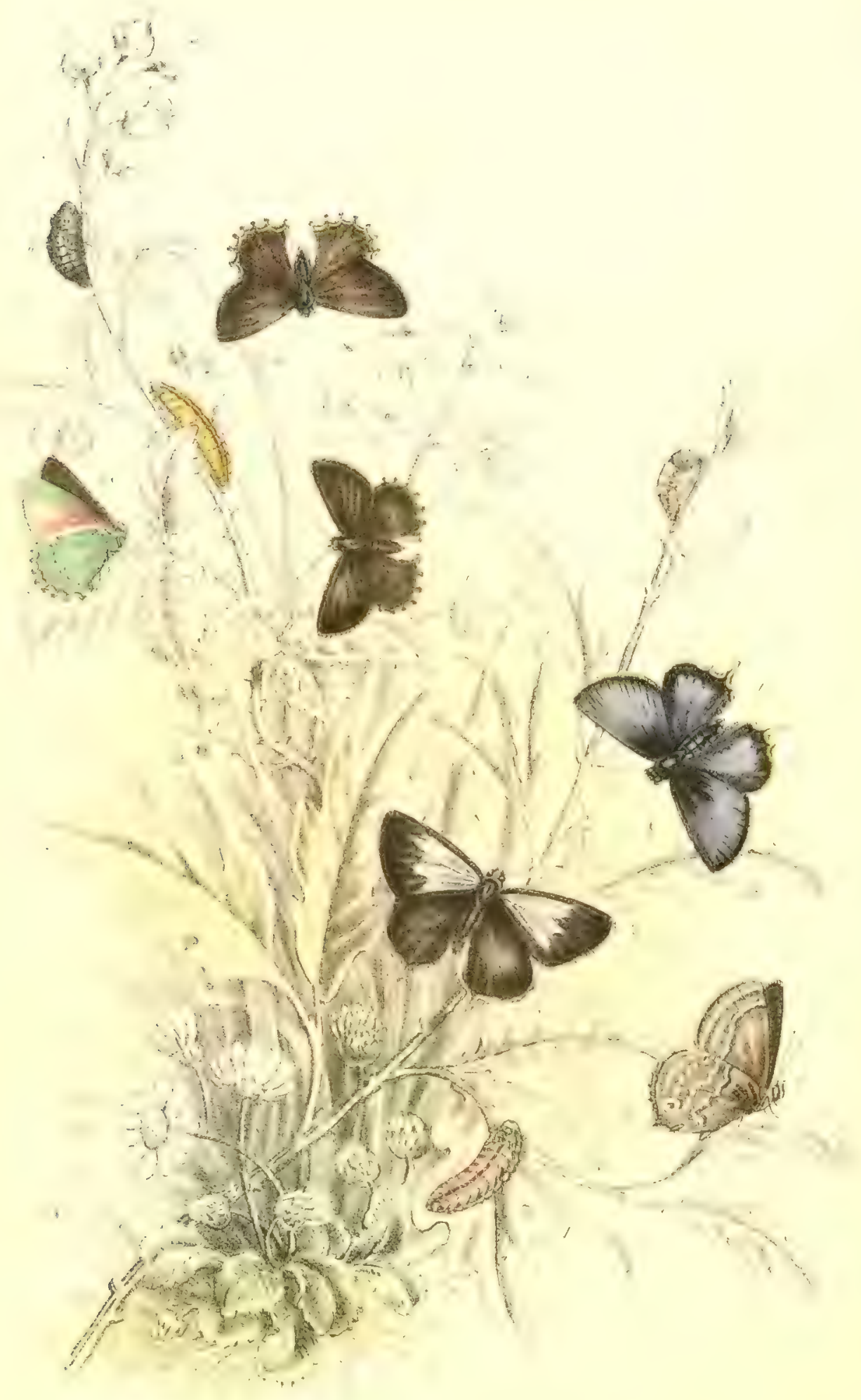




\section{PLATE XXII.}

No. 1. The Purple Hair-streak Butterfly (Thecla Quercits).

No. 2.-The Female of the Purple Hair-streak Butterfly.

Fo. 3.-The Under side of the Purple Hair-streak Butterfly.

No.4.-The Caterpillar of the Purple Hair-atreak Butterfly.

No. 5.-The Chrysalis of the Purple Hair-streak Butterfly.
No. 6.-The Green Hair-streak Butterfly (Thecla Rubi).

No, 7.-The Female of the Green Irair-streak Butterfly.

No. 8.-The Under side of the Green Hair-streak Butterlly.

No. 3.-The Caterpillar of the Green Hair-streak Butterfly.

No. 10.-The Chrysalis of the Green Hair-streak Butterty.

THecla QUerets (the Purple Hair-itreak). This sprecies is by far the handsomest of the British Therles. It is also a rery interesting species, as exhibiting most strikingly a peculiarity that distinguishes this genus. This peenliarity consists in the characteristic markings of the females, which, contrary to those of most other gencra, are more conspicuous and hrighter than those of the male. In Thecla Betule (Plate xxi.), we have seen that the female is distingmished by a fine patch of orange on the anterior wings, which is not found on those of the male. In Thecle Prini the female has a border of orange on the fore wings, while thuse of the mile are entirely brown. In the species now under description, the markmgs of the female are atill more conspicuously different from those of the male-and of much greater comparative brightnens, as they consint of large patches of the brightent metallic azure, while the wings of the males ares of unvarying dusky purple, rexing towards brown. The bright metallie blue rearembles that which forms the ground colour of the wings of the male "Purple Emperor ;" the female of which species has the ground coloux of the wings of dusky l, mown-lyeing. in fact, much lens brilliant in its colouring than the male; and this and other similar instances lerl our English entomologists to conclude that the most dusky toned of the sexes in Therle Guerits was necessarily the female, This supposition has been now satisfactorily dinproved, as the individuals with the

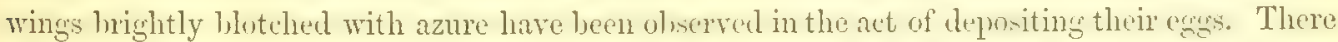
are also distinctions in the form of the anterior feet of the two suxes, analogons to these of some preceding fumilies, which also serve to prove that the largest and most lightly culoured indivirluals in this genus are invariahly the females. The character of the feet in the genus Thertu was first noticed by Dr. Horsfied, in his description of some of the magnificent The lis of the island of Java. The male is represented at No. 1, the female at No. 2, and the under side at No. 3. The Cateppillar (No. 4) feeds upom the fillage of the Oak in May and June, ant sometimes hurrows in the gromed at the time of its changere to the C'hrysalis state, thengh it is mot frequently found attached to a branch or the under side of a leaf, by a silken web. Réaumu gives a most interesting and a detailed account of the manner in whirh the Caterpillars of this genus attach the wels round the body, which secures them during the Chry salis state. The perfect insect appears in July.

It is pretty generally dispersed, and plentiful in the Southern countie, and is also found in 
several localities in the North; but is very rare in Scotland. It has been recently taken in sreat abundance at Brighton, Epping, Exeter, Tenterden, and other places.

Thecla Rubi (the Green Hair-streak). This is the least Thecla-lilie of any of the British species, being nearly without the elongation of a portion of the hind wings, which is one of the

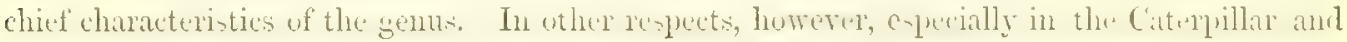

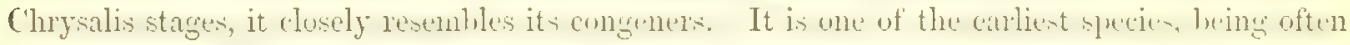
fonut in Miry. The male, the female, and a specimen showing the umler sirle of the winge, are figured at Nos. 6, 7, and 8 .

The Caterpillar (No.9) feeds on the common Bramble, and also on Papilionaceons, or Peaflowered, plants. It may be found in May and June, and again in August. The antumnal

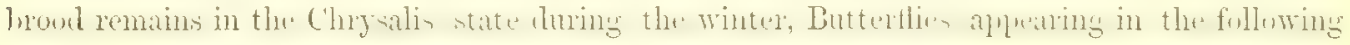
May. The perfiect insects resulting from the sumg hood of Caterpillars, alldear aljout the beginning of August.

It is very generally distributed, and rather common-being found in some abundance in most of the English counties, and in the south of Scotland, but rarely further North.

Mr. Stephens describes a varicty in which the white dots on the under side are much more conspicuous; and also one in which the anterior wings of the female hare a pale whitish spot near the centre of the anterior wings. It has been recently taken at Teignmouth in great numbers.

The other species-Thech Spini and Thedu Ilicis-were formerly considered British by some collectors, but they are both omitted in recent catalogues. 



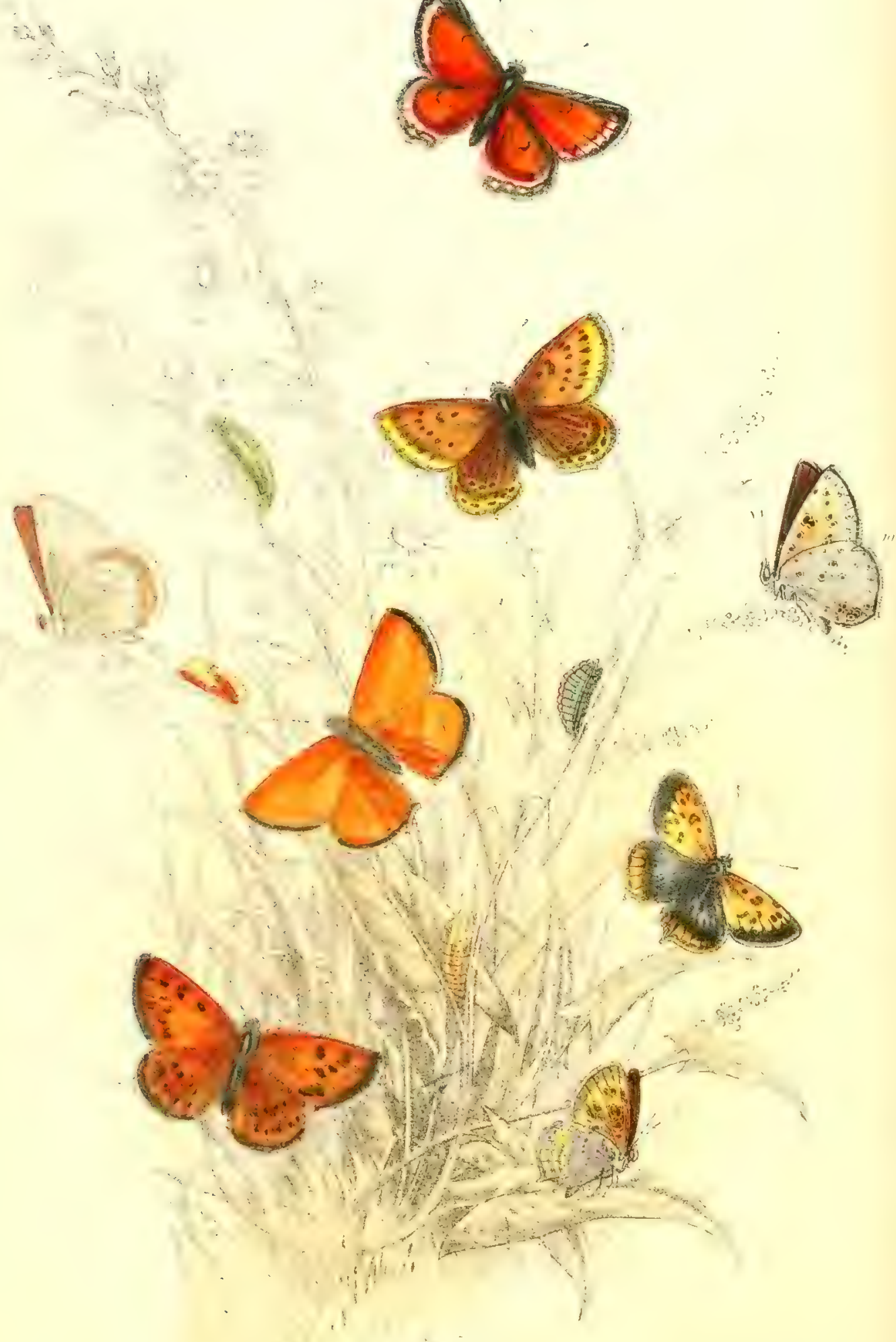




\section{PLATE XXIII.}

No. 1.-Tho Copper Butterfy (Chrysophames Phlceas). No. 2.-The Copper Butterfly, showing the Under side.

No. 3.-The Caterpillar of the Copper Butterfy.

No. 4.-The Chrysalis of the Copper Butterfly.

No. 5.-The Dark Under-winged Copper Butterfly (Chrysophanus Hippothoë).

No. 6.-The Female of the Dark Under-winged Copper Butterfly.

No. 7.-The Dark Under-winged Copper Butterfly, showing the Under side.
No. 8.-The Purple-edged Copper Butterly (Chrysophanus Chryseis).

No. 9.-The Female of the Purple-edged Copper Butterily.

No. 10.-The Purple-edged Copper Butterfly, show. ing the Ender side.

No. 11.-'The Caterpillas of the Scarce Copper Butterfly. (The Butterly in Plato xxir.)

No. 12.-The Chrysalis of the Scarce Copper Butter. fly. (The Butterfly in Plate xxiv.)

THe genus Chrystphemus, which follows Thecte in the heautiful family of Lyecnite, is so distinct from its predecesor in many reapects, that it would seem almost to mark the commencement of a new family. The Theclas, so peculiar in regard to the superior brightness of the colouring of the females, and also in the tail-like appentige to the hime wings which is always present in good typueal suecies, which seem to distmeniwh them as a serparate fanily, misht be donominated the Thectida; while the genus Chrysophanus, along with Polyommatus, might be formed into a separate family by Swainson's title of the Polyommatide, as both genera exhibit the numerous cye-like ringed spots on the under surfice of the wings, to which the dercriptive

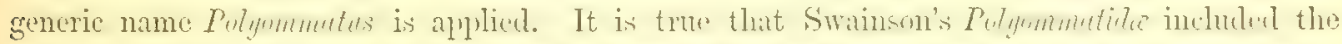
Thedes, which might however be separated, renerving the fimily tith only for the two senera to which its meaning applies. This, howerer, is a mere slesestion to the collector to incite hin to consider any system of classification with resard to its merits, and not receive it withont exanination; for I am hound in this volume to the systom now alopterl in the British Musem, as

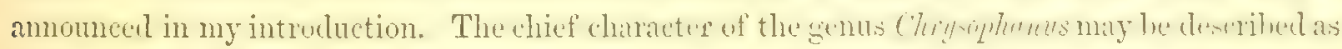
follows: First, the rich gold-like colouring of the wings of the miales, which has given line to the

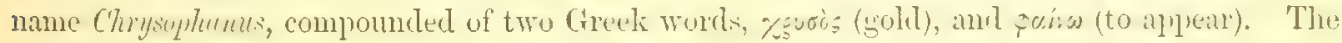
metallic golden he is, however, of a deep red tone, which has sugegestert to onr native collecturs the popular name of "Coppers." Secondly, the slight pointing of the lind wings, which in the first species, Phleuts, extends into a short tail, which makes that species form a convenicht gratation from the genus Thecte to the present genus. Thirdly, the wings of the males are the most brilliantly coloured, those of the females being of more dusky tone, and always varied by black spots which (with the exception of the rery rlistinct species ('. Phlares) never oceur in those of the males. Fourthly, the Caterpilliur, thongh more or less onisciform, are lomerer ancl not so

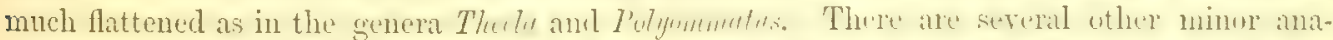
tomical characters connected with the knohs of the antenna, the forne of the pallit, and the veining of the wings, the detailed description of which would be out of plues in a strictly pepular work.

Chrysophanus Phlceas (the Copper, No. 1). This pretty species is common in all parts of the comtry. There is no difference in the markings of the two sexes in this species, thumbh they are so distinct in the others of the genus; the hind wings liave also short tails resemijling those of the Theclas, as stated above. 
The Caterpillar (No. 3) is green, with a red stripe on each side. It feeds upon the common Sorrel, Pumce acefosa; and there are most proluably sereral broods, as the perfect insect appears in April, June, and August.

The Chrysalis (No. 4) is foumd attached to the stem of the Sorrel. This pretty Butterfly is common everywhere, especially on heaths and commons; where, being a pugnacious insect, it is observed giving battle to intruders upon its domain, often engaging in combat with some of the largest of the Buttertly tribe. There are sereral striking rarieties of this pretty species. The one in which the copper border of the hind wings is wanting, is perhaps the commonest. In another variety, the copper colour on both the surfaces of the wings is replaced by milliy white, leaving the dark spots. Another has the deep copper colour reduced to a pale orange, and the black spots and black portions of the hind wings are white. These rarieties are more or less rare, and, as I am informed by Mr. Bond (whose well known collection of British Lepidoptere is one of the finest in the country), such varieties are in most instances confined to particular districts, in each of which not more than one of the rarieties is found.

Chrysophanus Hippothoe (the Dark Under-winged Copper, Nos. 5 to 7 ). This species is omitted in many Catalogues of native Lepidopterc, the ground for supposing it a British insect being considered doubtful. "The best-known "Britislı' specimen," writes Mr. WTestwood, "was obtained from an old collection made in Kent, which was lnown among collectors as the "Kentish Cabinet." Some have supposed the species identical with C. dispar"; but a comparison with the figures will sufficiently prove their distinctness. The true Hippothoe of the Continent is invariably much smaller than our $C$. disper, and is of lighter colour in the centre of the wings, shading to deep purplish on the edges; while in C. dispur (in the males) the intensity of colour is the same all over the upper surface of both pair of wings.

Chrysophumus Chryscis (the Purple-edged Copper, Nos. 8 to 10). This species has also become of extreme rarity, though formerly taken near Epping, from whence Dr. Leach is said by MIr. Stephens to have received fresh specimens during several successive seasons. It was also taken at Ashidom Forest, Sussex. On the Continent both this and the list species are plentiful, in marshy places in some districts, where they appear towards the close of summer. 



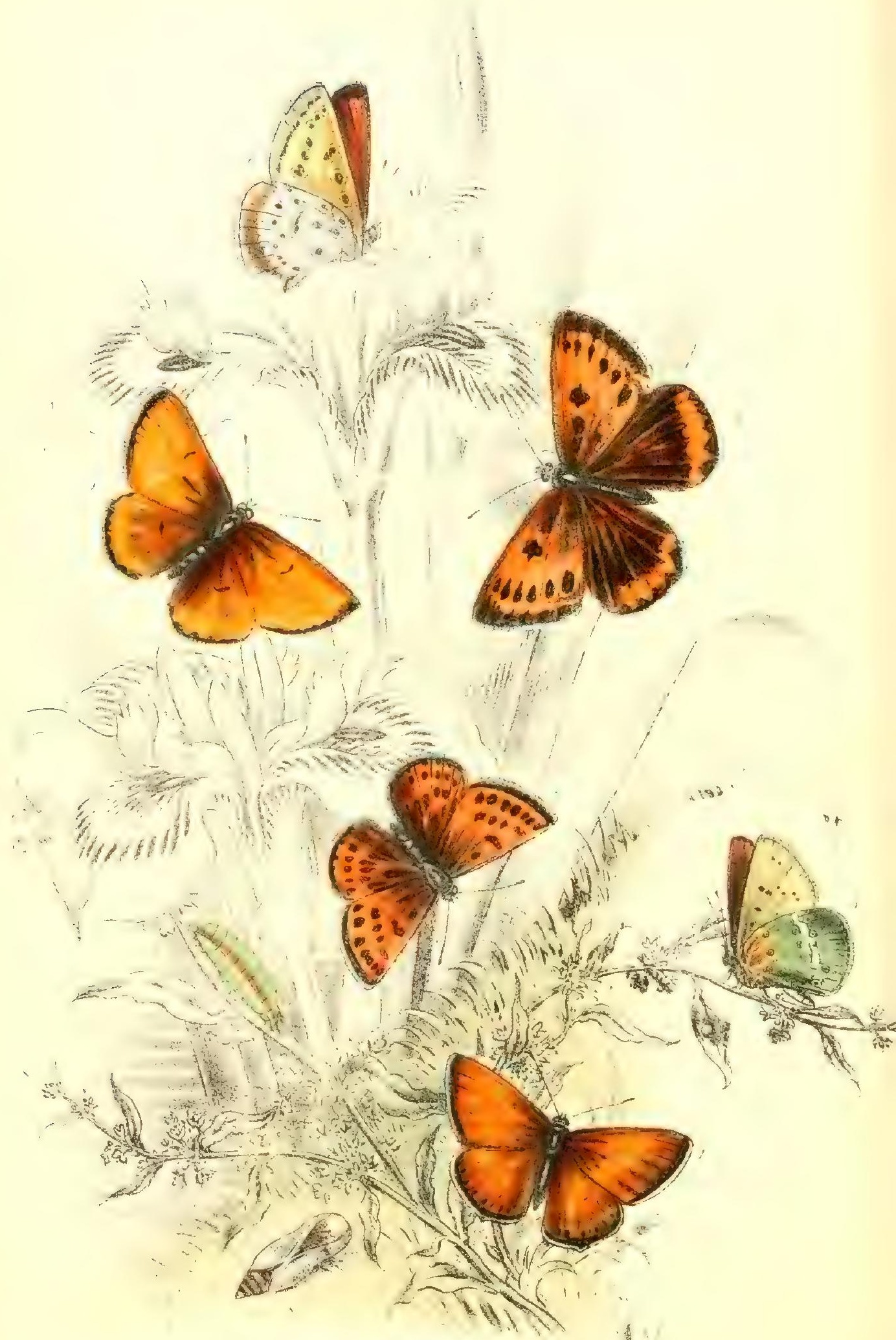




\section{PLATE XXIV.}

No. 1. -The Scarce Copper Butterfly (Chrysophanus Virgaurece).

No. 2.-The Female of the Scarce Copper Butterfly. No. 3. The Scarce Copper Butterly, slowing the Under side.

No. 4, -The Large Copper Butterly (Chrysophanus dispar).

(Tho Caterpillar and Chrysalis of the Staree Copper Butterly are represented in Plate sxiii. at Fos. 11 and 12. )

Chrysopilanus Virgauree (the Scarce Copper, Nos. 1 to 3). This species is the first of the true Chrysophani. The rich copper-coloured wings of the male (No. 1), are free from black spots, except close to the border of the hind wings; those of the female (No. 2), having numerous large black spots. The Caterpillar (No. 11, Plate xxiii.) is onisciform, but not flattened; and the Chrysalis (No. 12, Plate xxiii.) is secured to a leaf or stem by a knob of web at the tail, and a girth at the middle. The under side (No. 3), is less distinctly marked than any of the old species by the ocellated spots which distinguish the genus.

The Caterpillar feeds on the Golden-rod (Solidago Virgarucece. This species has not been recently taken, and is considered by some to be doubtful as British, notwithstanding the

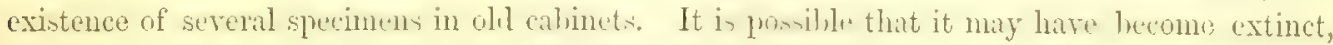
as we have seen $C$. dispar entirely disappear within the last few years.

Chrysophanus dispar (the Large Copper, Nos. 4 to 8). This beautiful and conspicuous

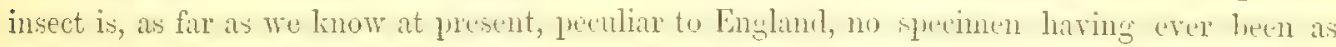
yet taken on the continent of Europe, or in any other quarter of the world. M. Boisduval, however, thinks it a large local variety of the Contin'ntal C. Ifipmother. Howerer this.may he, there has been so great a demamel for this heatiful insect wince the appearanee of the figure of it in Donovan's work, that the species is supposed to he extirpaten-recently captured specinens

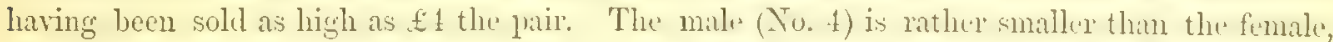
but of much more brilliant colour. The female (No. i) is marked with large black sputs, and the hind wings are nearly black, with a copper-coloured border. There is a female variety in which the borker of black on the front wings is much nawner than in the speeinen figured, and in which the copper-eolonerel boreler of the himel wings is much more duaky. The under side (No.6) has the ocellaterl spots much mone strongly and clearly manked than any uther species of the genus, and is the same in both sexes.

The Caterpillar (No. T), which feeds on the Creat Water Dock (Timudis aputicus), is pale green, thickly powdered with white specks, and appears in June.

The Chrysalis (No. S) is at first green, then galv arle coloured, and eventually (in some specimens) deep brown.

The perfect insect appear's in July and August, and was formerly abmelant in the Fenny districts of Huntingdon and Cambridge shires ; and it has been taken at Benacre in Suftulk, and 
Bardoly Fen in Norfolk. So actire has been the pursuit of this beautiful insect during the last twenty years, that, as above stated, it is now sought for in vain in the haunts but recently so brilliant with its metallic hnes towards the close of each summer. It is thought, however, by some entomologists that it may reappear in some favourable season, as insects occasionally do, in a manner which has not been satisfactorily accounted for. It is possible, by a provision

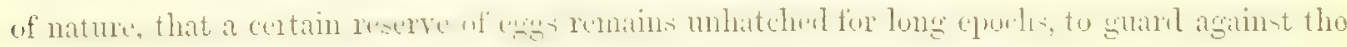
extinction of species by unfavourable seasons; but whether from this or other causes, it is

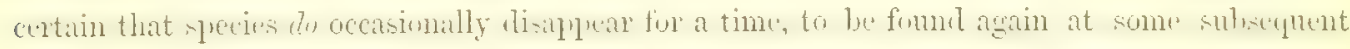
period. It has been noticed by Lacordaire that in common species of Lepidoptera, a certain portion of the eggs frequently remains unhatched the first season, which, so far from being

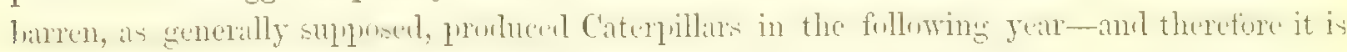
possible that in some cases the vital principle may remain domant for longer periods.

Mr. Bond, who has frequently chased the C. dispar on the wing in the Fens of Cambridge and Huntingdon, says, "It is difficult to capture, seldom affording an opportunity for a second stroke of the net if the first have been unsnccessful." This, horrever, is of little consecuence to young collectors, as matters stand; for it seems they are not likely again to have an opportunity of exerting their skill in the capture of this coveted prize of the British Lepidopterist. 



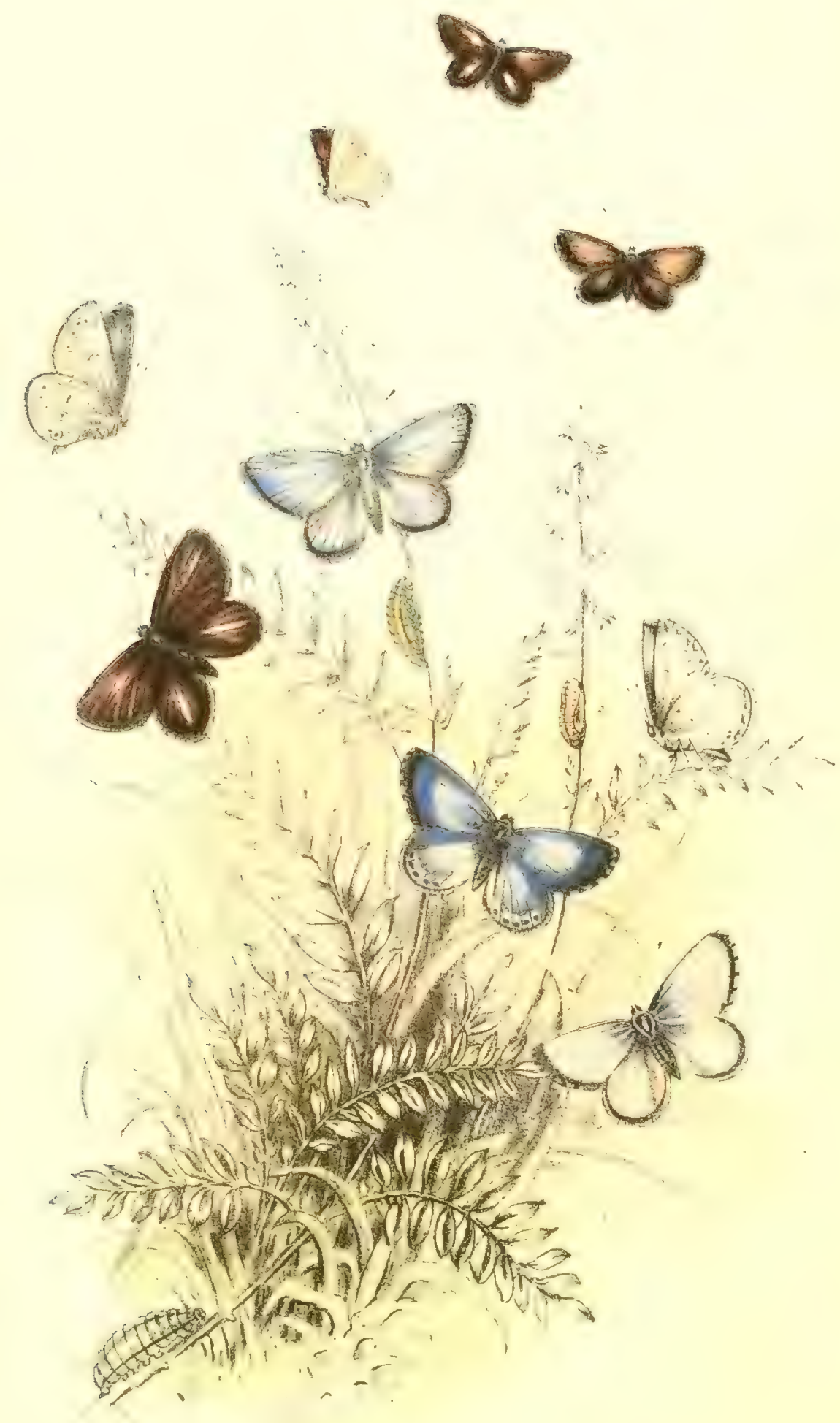




\section{PLATE XXV.}

No.1.-The Azure Blie Butterfly (Polyommatus Argiolus).

No. 2.-The Female of the Azure Blue Butterfy.

No. 3. -The Azure Blue Butterly, showing tho Under side.

No.4.-The Small Blue Butterly (Polyommatus Alsus).

No. 5.-The Femalo of the Small Blue Butterly.
No. 6.-The Small Blue Butterfly, Bhowing the Uncler side.

No. 7.-The Caterpillar of tho Small Blue Butterfly. No. 8.-The Chrysalis of the Small Blue Butterly.

No. 9.-The Jazarine Blue Butterily (Polyommatus Acis).

No. 10.-The Female of the Mazarine Blue Butterfly. No. 11.-The Mnzarine Blue Butterify, sliowing the Uncler side.

TrE genus Polyommatus. This genus is principally distinguished from Chrysoplumus by the bright blue colour of the upper surface of the wings of the males. The females are generally brown, or at all erents of a cluller colour than the males, and in a few species both sexes havo the upper surface of the wings brown. The under sides of the wings closely resemble those of the insects assigned to the genus Chrysophanus, presenting, however, certain differences to be described in speaking of the respective species.

The Caterpillars are onisciform, the head and feet very small, and scarcely observable witlout minute examination; they are generally yellowish-green, variegated by markings of red, brown, or yellow. They feed generally on the foliage of Papilionaceous, and other low growing plants; that of $P$. Argiolus, however, feecls upon the Holly, preferring the flowers. The

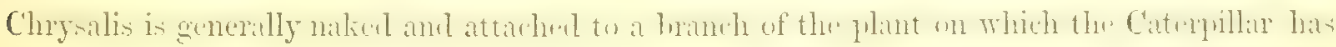
fed; but in some cases the Caterpillars burrow in the earth to undergo their transformation. This genus has representatives not only in all parts of Europe, but in North and South Africa, the East Indies, and North America, while but very few of the species are lnown in Soutl America.

Polyommatus Argiolus (the Azure Blue, No. 1). This is a very delicate and benutiful little Butterfly. The azure of the upper surface is of a soft and pleasing tone of light blue, and the

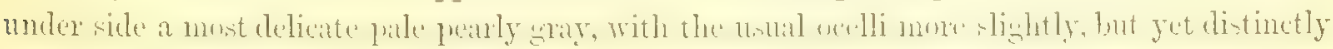
marked. The female differs in size, not as in the genus Chrysophanne from being larger than the male, lut on the contrary smaller. In addition to the smaller size, the female may be at once distinguished by the more dusky colour, and by the deep black border of the anterior wings, and the dotted border of the hinder pair.

The Caterpillar is described by Ochsenheimer as being of yellowish-green, with a clouble line along the back. It feeds on the flowers of Holly, and also it is said on those of the Iry. The later brood probably do, as the Holly is out of bloom when they appear; some entomologists, however, assert that there is only one brood of this pretty species, though specimens of the perfect insect are taken as early as April, and as late as $\Lambda$ ugust.

The Chrysalis is brown, with a deep dorsal line.

The Butterfly is very distinct in its haljits, most of its congeners being generally found in

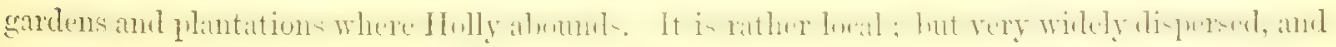
in some places plentiful, being found quite in the North of England, but not in Scotland. 
Polyommatus Alsus (the Small Blice, No. 4). This is the smallest of our native Buttertlies. Though termed by collectors one of the "Blnes," the upper surfaces of the wings of both sexes are brown; those of the male, however, laving a flush of blue near the base. The under side resembles that of the other I'olyommoti. The Caterpillar of this species (No.7) feeds upon the Alpine Milk Vetch (Astragalus Ciccr), the Clnysalis being attached to a stem of the same plant. The Butterfly appears in MIny, and again in July and August. It is most plentiful in chalk and limestone districts, but is often found in some abundance in other localities.

Polyommatus Acis (the Mazarine-Blue, No. 9). This handsome insect is conspicuously different from the other species in its deep full blue, which has a satin-like gloss that gives it great brilliancy. The upper surface of the wings of the female are dark brown, with only a light purple flush towarcls the base.

The Caterpillar is unlinown.

This is a rare species; but it is in some seasons talien in some plenty in challiy districts. It appears in May and June, and again in August, being double brooded. Mr. Newman states that it was formerly plentiful in Herefordshire, and supposes it to be still plentiful there; but Mr. Allis writes to Mr. Stainton that he knows of no capture within the last seven years. 



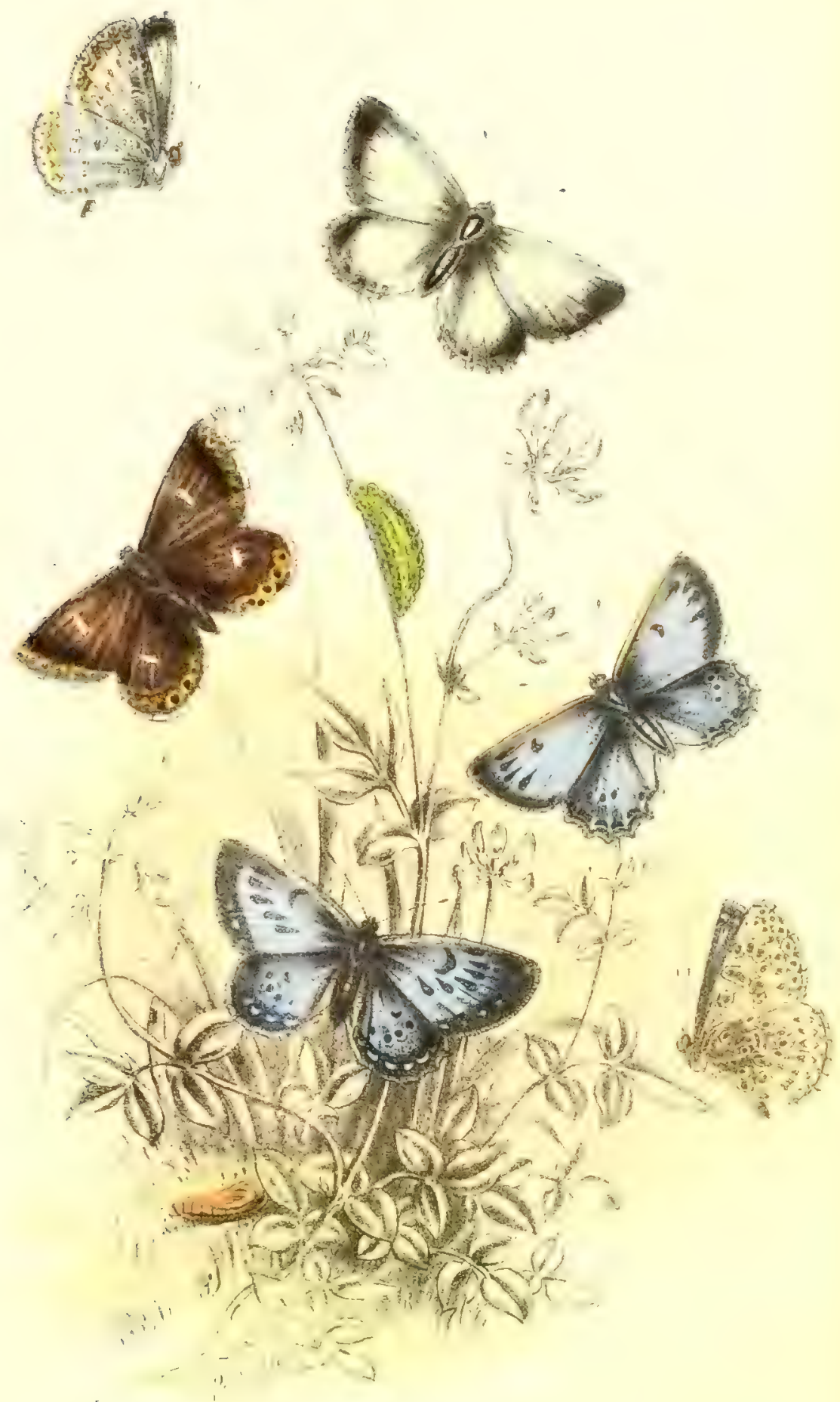




\section{PLATE XXVI.}

\section{No. 1.- The Large Blue Butterfly (Polyommaius Arion).}

No. 2.-The Female of the Large Blue Butterilf.

No. 3. - The Large Blue Butterlly, slowing the Under side.

No. 4. -The Chalk-hill Blue Butterfly.

No. 5.-The Female of the Chalk-hill Blue Butterfly.
No. 6.-The Chalk-hill Blue Butterfy, showing the Under side.

No. 7.-The Caterpillar of the Chalk-hill Blue Butter. Aly.

No. 8.-The Clurysalis of the Chalk-hill Blue Butterfly.

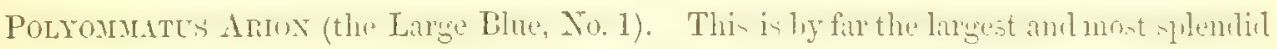
of the "Blues," as the blue section of the Lycenidce are popularly termed by our collectors. It was at one time considered extremely rare, and by some scarcely believed to be a true British

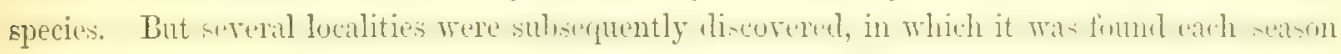
in some plenty, and the further discoveries of more recent lepidopterists have removed all doubts as to its being a native species. The spots on the wings of the male differ rely cunsiderably both in size and intensity of colour; the figure (No. 1) being taken from a specimen of medium strength in the marking. The Frmale (No. u) is generally rather linger than the male, and has the spots and dark borders broader, but less strong in colour; and the blue ground is

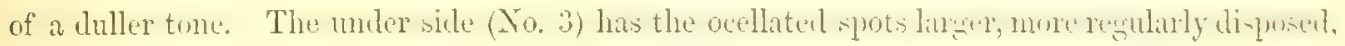
and more sharply defined than any other of the genus.

The Caterpillar is unknown.

The perfect insect appears in July, and the lecalities in which this entomological prize in

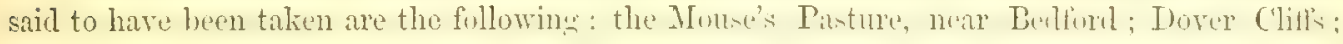

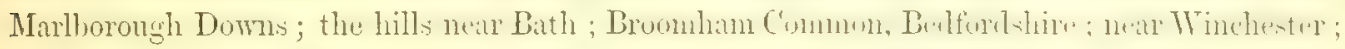
and in one or two localities in North Wales. But the most celebrated locality, and one in which

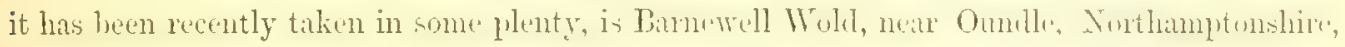
in which place the Rev. W. Bree states in a communication to the "Zoologist" for 1852, that

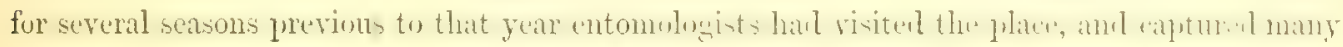

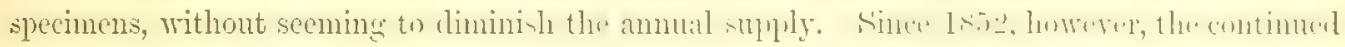
pursuit appears to have grievously diminished the numbers of this beatiful insect in this locality; and we may therefore look forward to its becoming extinct in Barnewell Wold, as C. dispar has done in its once favourite fens of Cambridge and Huntingdon. In the yen alove

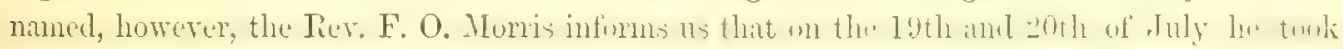
no less than eleven specimens.

Polyommatus Corydon (the Chalk-hill Blue, No.4). This species is the next in size to $P$.

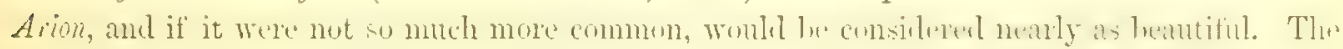

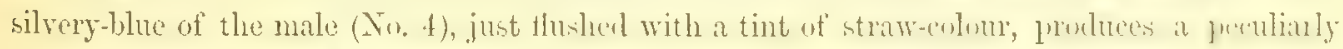
delicate effect, which is hejghtened loy the dark homler, hecoming nearly black at the law of the fringe. The wings of the female (No.5) are of rich brown, with a slarp touch of white near the centre of each; and an ochreous border with black lots, both border and dots being much more conspicuous in the anterior wings than in the hinder pair. 
The under side (No. 6) is not so symmetrically decorated with the usual ocelli as P.Arion, but it is, nevertheless, very distinctly and beautifully marked.

The Caterpillar (No.7) is said to feed on severn species of Vetch, and also on the wild Thyme (Thymus Sermyllum).

The perfect Butterfly appears in July, and is tolerably plentiful in the localities which it favours, principally in chalky districts. Some of the localities in which it has been found most regularly and atomdantly are the following:-Dover, and many other places along the southern coast; Newport in the Isle of Wight; Darenth. Wood, Kent; sereral places in Suffolk, and Oxfordshire; and abundantly near Newmarket, Cambridgeshire. It is also found in the Prestbury Hills, near Cheltenham, and in some localities in the neighbourhood of Winchester and near Great Bedwyn, Wiltshire. It must formerly have been much more abundant than now; as it often ontmumhers many species in the Butterfly pictures, or rather stars, and ofler similar devices formed by the Spitalfields wenvers in years gone lyy, with the specimens which they then captured for no other murpose. I purchased a small collection of Buttertlies in a rough home-made cabinet a few years ago, in which one entire tray was filled with specimens of $P$. Corylon, among which were many rather striking rarieties, but all in a bal condition. The male is sometimes so strongly suffused with brown, that it closely resembles the female, for which it might easily be inistaken ly an inexperienced collector. 



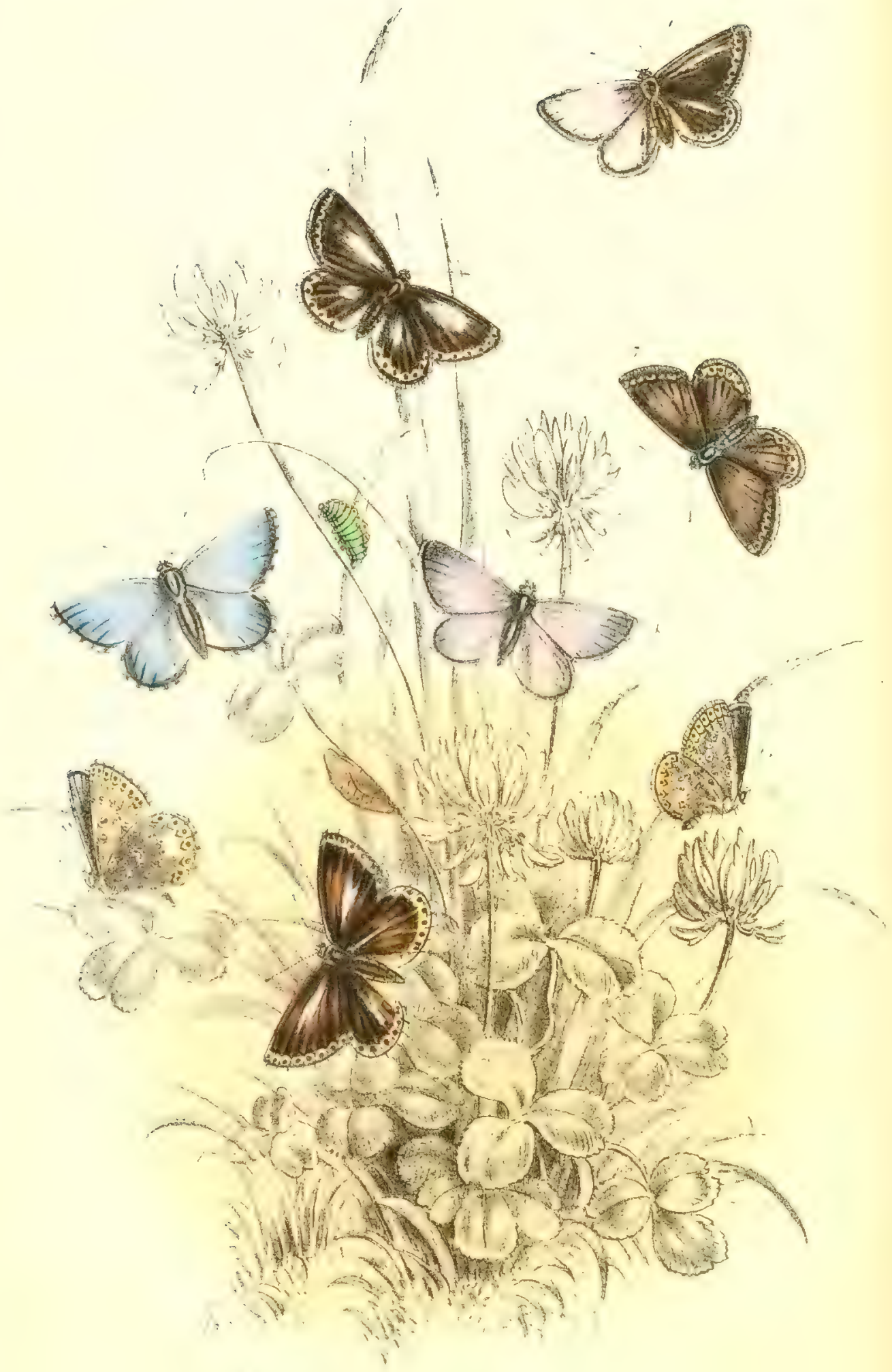




\section{PLATE XXVII.}

No. 1. The Clifden Blue Butterfly (Polyommatus Adonis).

No. 2. The Female of the Clifuen Blue Butterfy.

No.3.-The Clifden Blue Butterfly, showing the Under side.

No. 4.-The Common Blue Butterfly (Polyommatus Alexis).

No. 5. - The Female of the Common Blue Butterfly.
No.6.-The Common Blue Butterfly, showing the Under side.

No. 7. - An Iermaplurodite rariety of the Common Blue Butterlly.

No. 8.-The Caterpillar of the Common Blue Butterfly.

No. 9. The Chrysalis of the Common Blue Butterfly.

Potyomatus Adons (the Clifden Blue Butterfly, No. 1). This insect, in so far as the colour is concerned, is the most beautiful of the "Blues." The azure of the upper surface of both pair of wing is of the most delicate silvely hlue, the eflect of which is at the same time heightened and refined by the snowy whiteness of the fringe.

The female (No. 2) has the upper surface of the wings of rich deep brom, but having towards the base a flush of rich violet blue, which is much brighter and more distinct in some

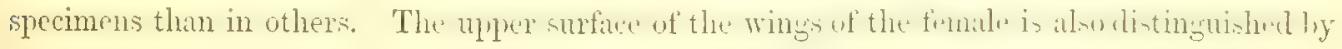
borders of a lighter colour, containing a row of black spots; the borders of the hind wings being of a dusky orange colour, while those of the anterior wings are merely of a pale brown. It is rather difficult to clistinguinh the female of this species from that of $P$. ('orytue, lut $P$. Corydon has a black spot on the upper surface of the hind wings which is absent in Adonis. The female has also, occasionally, white specks in the centre of the fore wings.

The under side (No. 3) is rery delicately enriched with the nsual ocelli, and is distinguished from that of $P$. Coryten ly the small and more delicate eharacter of buth groment colour and markings.

The Caterpillar, according to Freyer, is of the mslitl oniwiform character ; of rlark green colour, with two rows of short yellow streaks on the hack, and a yellow longitulinal stripe at cach end. Ochsenheimer describes it as feeding on several species of pea-flowered plants.

The perfect insect appears in May and June, and is chiefly found in chalky districts. Dartforl, in Kent, was formerly a farourite lecality with Lomdun collector's fur this beautiful insect. It has been recently taken at Brighton in great abundance.

Polyommatus Alexis (the Common Blue Butterfly, No. 4). This, though one of the most ahundant of our native Butterlies, common in almot every clistrict of the country, is a remantiably pretty insect; and though inferior to $P$. Allonis or $P$. Arion, has yet beauties of its om which seldom fatil to attract even the minitiated observer. The l, lue of the mper surface of the

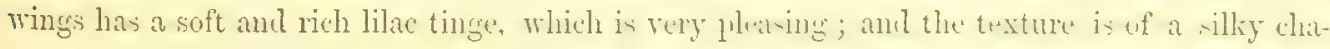
racter, which shows off the colum to the greatest alvantage. "The one reperented at Xo. 1 is rather a dark specimen, the colome varying consilerably in ditherent indivilnals. The female

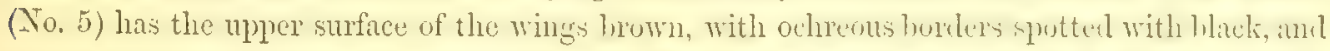
with a slight flush of blue turarls the hase. The under side reperentiel at Nu. 6 is of the usual character, and like that of all the other species nearly alike in both sexes. 
The Caterpillar (No. 8) feeds most commonly on Lucerme, in April, and again in September, there being two broods in the year. It also feeds on Clover and Bird's-foot Trefoil.

The Chrysalis (No.9) is attached by a girth round the middle to a stem of the plant on which the Caterpillar has fed. There are many varieties of this pretty species, principally among the females. Some of these have the brown scales of the upper surface of the wings so thickly intemingled with blue ones that the blue coloni almost preponderates, and the females have almost the appenrance of very dark coloured inales. But the most singular variety is that lnown as the Hermaphrodite (No. 8), which has the brown wings of the female on one side, and the azure wings of the male on the other. Other varieties were thought distinct species both by Lewin and Ilaworth, and Jermyn, and distinguished as P. Ifyacinthus, P. Thestylis, and P. Lucon. Some of these varieties are so constant in some localitics that one of our most accomplished entomologists (the late Mr. Stephens), even within the last few years was inclined to consider them distinct species. But recent observations of exotic Buttertlies have shown such extraordinary aberrations in the usual specific characters, that such distinctions as those alluded to must cease to be regarded as anything more than variations produced by some local influence, such as soil, climate, food, or some such other disturbing cause. Arnong the most remarkable aberrations in size and colouring of exotic Butterflies, evidently of the same species, those of the magnifcent Papilio Driamus may be cited. This gorgeous insect in its ordinary character, has the ground colour of the upper surface of the wings, of a full deep metallic green, while in a specimen just received at the British. Musemm the green is replaced by a perfectly distinct tone of rich orange yellow.

No. 7 is one of the more usual varieties of the female of $P$. Alexis, in which the wings are nearly as blue as those of the males, but have the distinctive borcler which is found in brown specimens. 



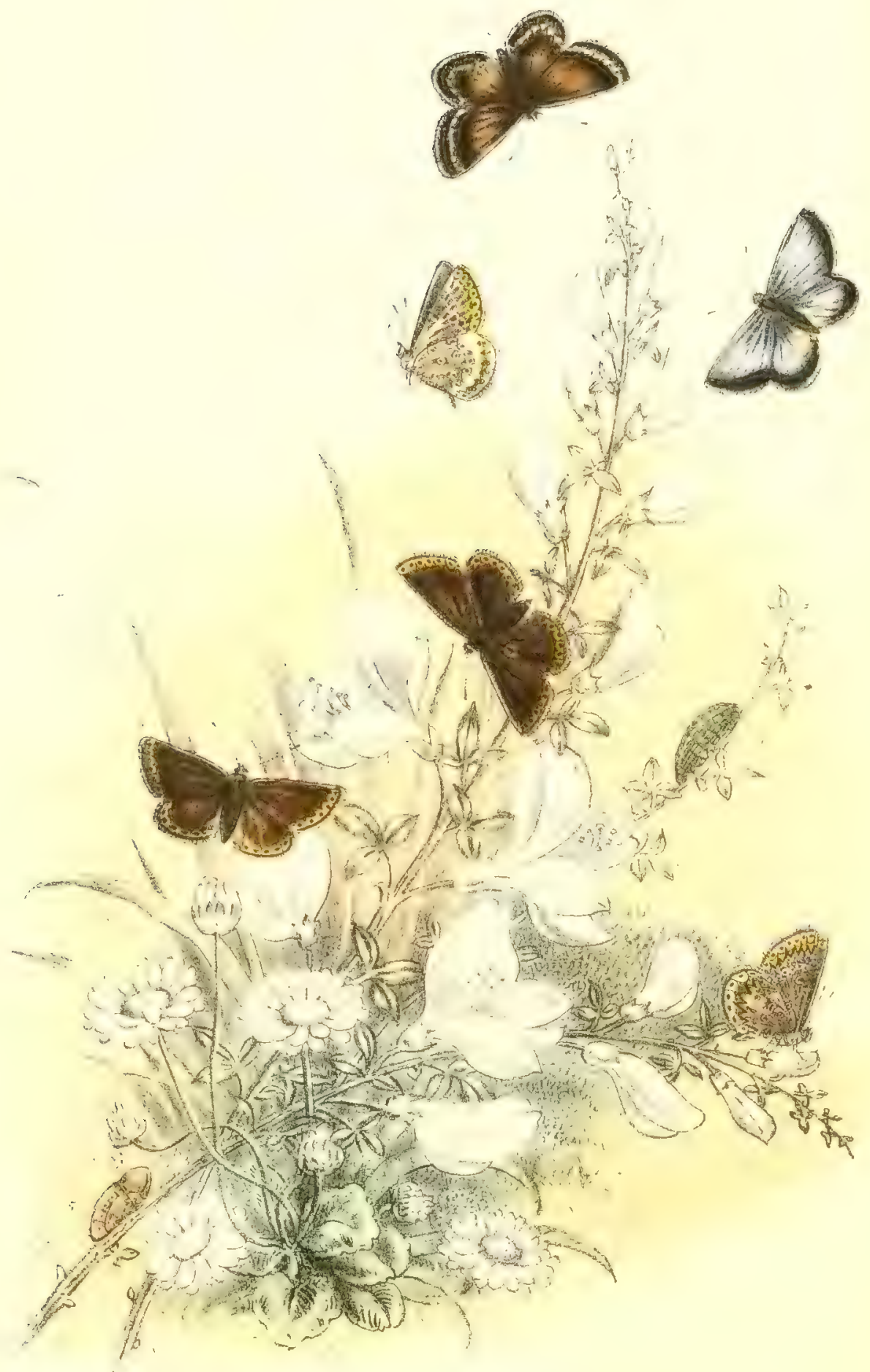




\section{PLATE XXVIII.}

No. 1. The Silrer-studded Blue Butterfly (Polyommatus Egon).

No. 2.-The Female of the Silver-studded BIto Buttertly.

No. 3.-The Silver-studded Blue Butterfly, showing the Under side.

No. 1.-The Caterpillar of the Silrer-studded Blue Butterily.
No. 5. -The Chrysalis of the Silver-studded Bluo Butterily.

No. 6.-The Brown Argus Butterfly (Polyommalus Agestis).

No. 7.-The Female of the Brown Argus Butterty.

No. 8. -The Brown Argus Butterfy, showing the Under side.

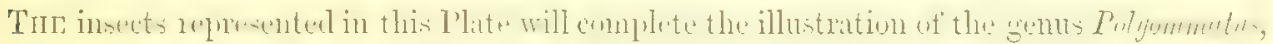
which has occupied the three preceding ones.

Polyommatus Egon (the Silver-studded Blue Butterfly, Nos. 1 to 5). This pretty species is

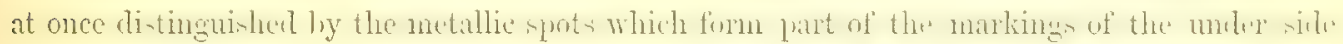
of the hind wings, and also by the dark blackish border to the blue on the upper surface of the wings of the male. The female (No.2) is rather larger than the male, and of a warm coppery

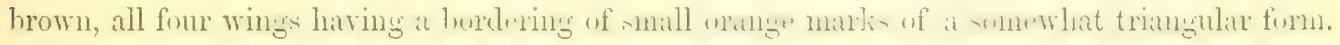
The under side of the wings, which is very nearly alike in both sexes, is shown at No. 3. The

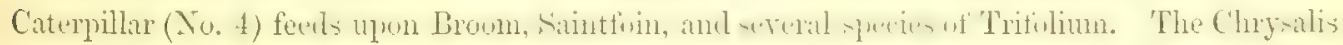
(No.5) is at first of a bright green colour, but as the shell hardens it becomes brown. The perfect insect is found on marshy commons or damp fields in July. It is very rarely found in the North of England, but in the Southern counties it is not uncommon, especially in certain

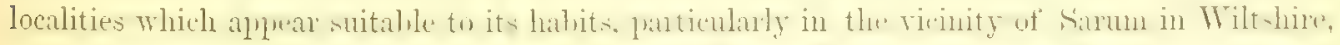

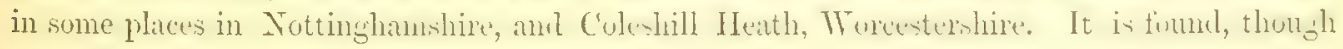
rather sparingly, in the metropolitan counties.

There are several rather remarkable varieties of this pretty species. One is a brown variety of the male-the upper surface of both pairs of wings being of a pale tawny colour. Another variety, formerly consilered a separate species under the mame of $P$. Alife, has the wings rery narrow, and the pale blue is bortered hy a much ialiex and mure distinct hand at the entgers. A third variety has the two rows of dots on the under surface running into cach other, and forming a series of dark stripes which give it a very distinet apleatrance. This specter war named $P$. meritimu, as having been fomm in the silt marshes near Holt, in Norfolk. There are several other varieties of this pretty species, but of a less remarkable kind.

Polyommatus Agestis (the Brown Argus Butterfly, Nos. 6 to 8). This rery distinct species has all the characteristics of the "Blues" except the blue colour of the upper surface of the

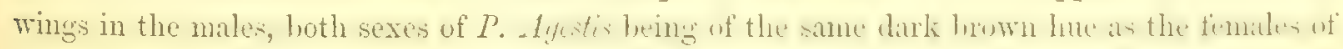
most of the other species. The male (No.6) is of a darker and brighter brown than the femalo.

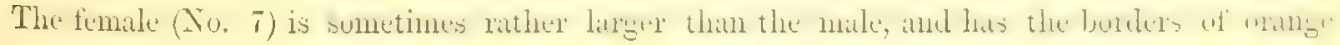


marks more conspicuous, the black spots within them being very strong in the lind wings. The under side of the wings, which is similar in both sexes, is shown at No. 8 .

The Caterpillar is described as being green, with a row of angular dorsal markings of a paler tone, and a central line of brown. It is found botl in April and June, the perfect insect appearing in June and August, this species being double-brooded.

Some anthors consider $P$. Sulmacis and $P$. ditarcmes as mere local varieties of the species

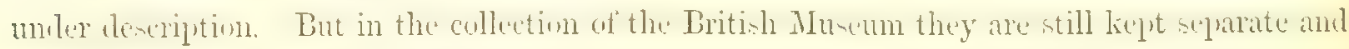
distinct, and will therefore be described as clistinct species in this rolume. 


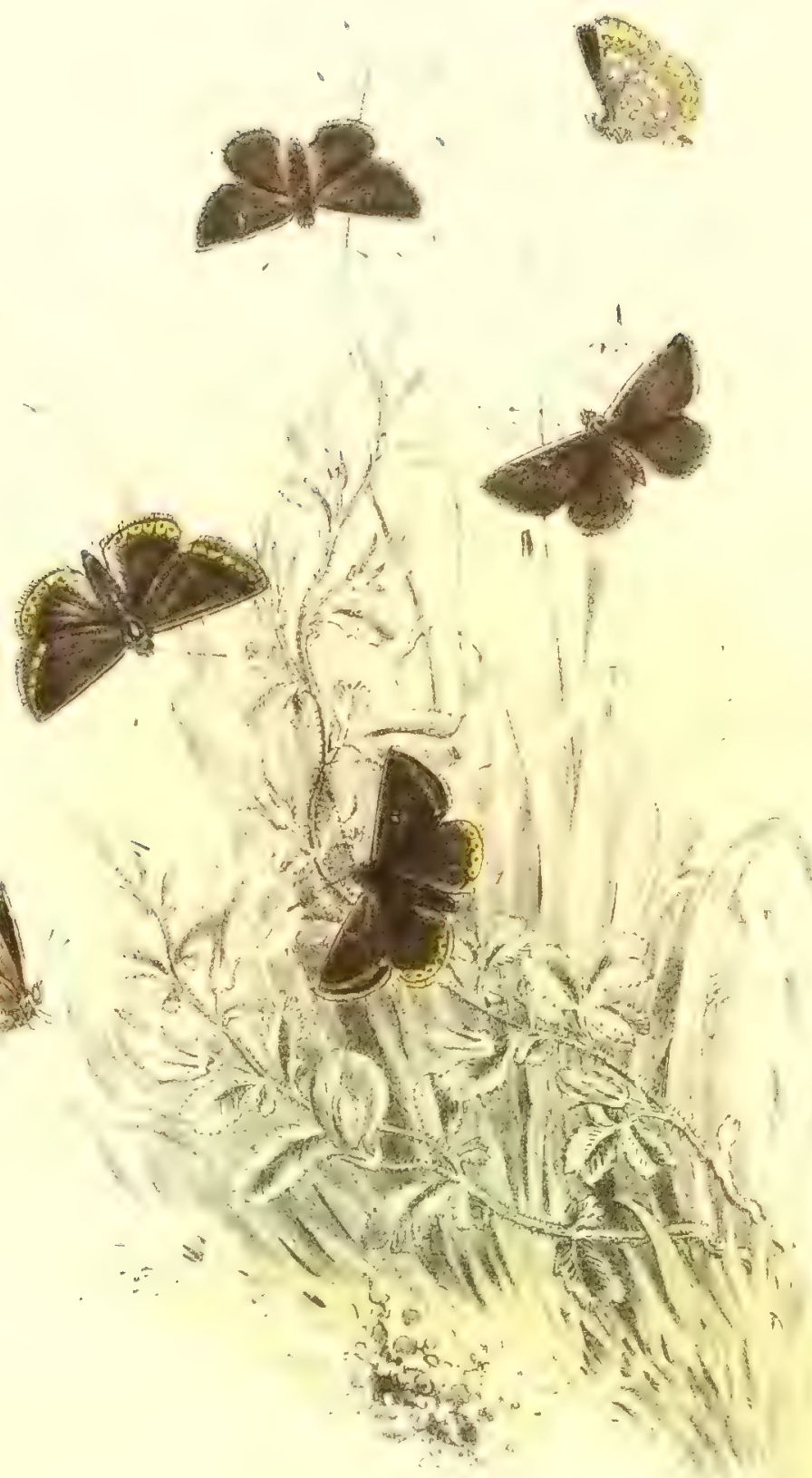


\section{PLATE XXIX.}

No. 1.-The Dark Argus Butterfly (Polyommalus Sal. macis).

No. 2.-The Female of the Dark Argns.

No. 3.-The Dark Argus, showing the Under side.
No. 4, The Scotch Argus Butterfly (Polyommatus Artaxerxes).

No. 5.-The Female of the Scotch Argus.

No. 6. -The Scotch Argus, showing the Under side.

By many British Entomologists the two species figured in this Plate are considered mere varieties of Polyommatus Agestis. It is, however, very dificult to draw a line which shall cor. rectly and satisfactorily separate certain slight deviations from a generic type, into distinct "species" on the one hand, and mere "varieties" on the other. In some cases the distinctions produced merely by climate and other local causes are allowed to constitute perfect and specific characteristics, while in others, equally striking differences are treated as mere variations. It would seem that where paticulat chateteristics are con-tantly and linglanly tran-nitted from

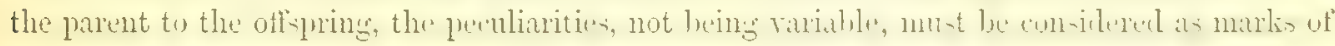
distinct species. On the other hand, when any such peculiarities of colour or structuro are evi-

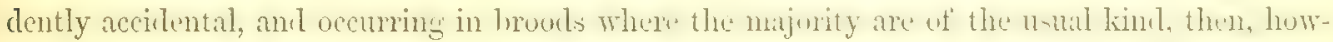
ever striking the differences may appear, they can only constitute "varieties." To meet tho first of these cases, the term "permanent variety" has been invented, while the insects clearly belonging to the second catenory are termerl simply "rarieties." But it may le farly asument that a "permanent variety" is precisely equivalent to a species. Such "permanent varieties" might be tested as to their claim to be considered species by removing broods of them to tho

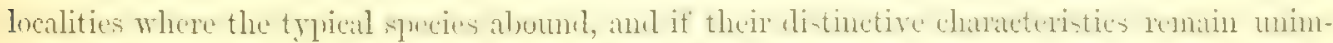

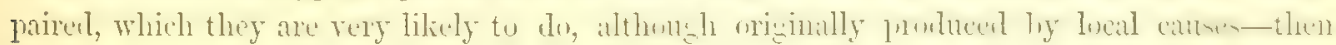
there could be no longer any doulbt as to their claim to be considered distinct species, for it is no doubt to local influences, acting throun a long series of ages, that many of the most striking "specific" characteristics have been produced.

If such a line of argment he almisihle, then, till further investigation throws more light on the subject, Polyommatus Sulmacis, which is only found in our northern counties, must bo

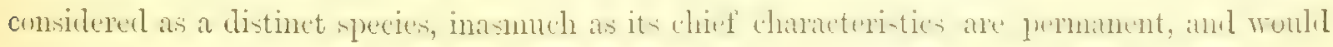
probably remain so, at all events for a long serics of generations, if a colony of it could be cstablished in a more southem situation. The same may be said of $P$. Arturerres. It is, how-

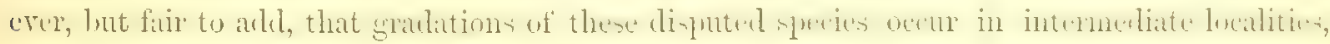
seeming to afford links between these two kinds, which would prove a very close relationship.

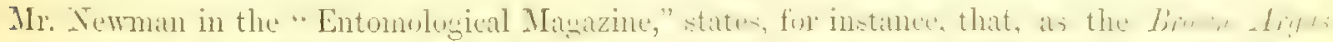

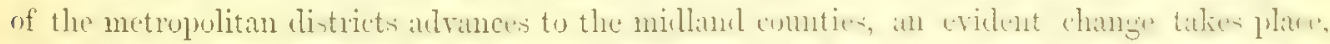

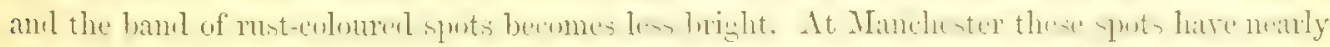

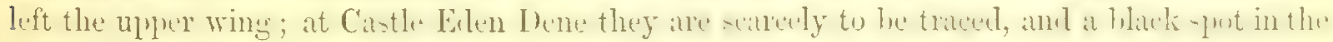
centre of the upper wing becomes fringed with white, being in some specimens quite white;

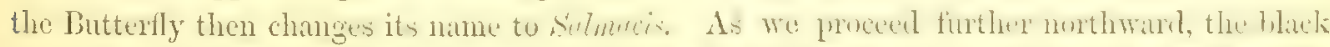
pupil leaves the "eyes" on the under side, mutil, at Eclinburgh, it is quite gone, and then thes insect is called Artaxcries.*

* Mr. Gardner informs us that all three specios lare been taken at Custle Eden Dene. 
It is probable that almost all other specific variations from a generic type might be traced in a similar manner through successive gradations, and the only question would then be, as to whether the term "species," or "permanent variety," should be the one adopted. Being myself

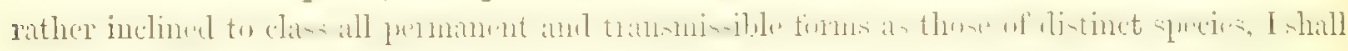
describe $P$. Sulmacis and $P$. Arturerres as distinct species, according to the arrangement adopted in the British Musenm.

Polyomatus Satmacis (the Dark Argus, No. 1). This species is generally conspicuously darker than the Brown Argus ( $P$. Agestis), and is further distinguished by an obscure black spot near the centre of the fore wings. The borter of dull orange markings of the fore wings are without the black spot in each which distinguishes a similar borter in the fore wings of Agestis; but in the hind wings the orange border has also the black spots. The female (No. 2) is only distinguishable by a white spot in the centre of the fore wings, and this mark is not a permanent distinction, as it sometimes occurs in the males, while the black spot appears equally transferred to the wings of the females. The under sile (No. 3), though slightly differing from $P$. Agestis, as will bo seen, presents no very striking distinction.

The Caterpillar stage of $P$. Sulnucis is mknown, or it might tend greatly either to establish or destroy its claim to be considered a distinet species. The perfect insect appears in July, and has only been found in the neighbourhood of Durham and Newcastle, seldom above half a mile from the sea. A single specimen has recently been talien near Brighton, which, though describer as $P$. Ayestis with an unusual white spot on its fore wings, is most probaluly a specimen of $P$. Sulmutic, which may yet be found at other points of the coast, if diligently sought for, as a marine species.

Polyommatus Artureres (the Scotch Argsus, No. 4). It was formerly thought that this pretty insect was only to be taken at Edinburgh, and in the sole locality of Arthur's Seat. It has, however, been recently captured in many other places in the north of England, as well as Scotland. The white markings on the under sile of the wing (No. 6), which are entirely without the usual black pupil, render it at a glance very distinct from all the other Polyommati, and the discovery of the larva by Mr. Logan, which is of a blueish green, with a dark dorsal line and a pale lateral one, and in other respects differing from the larvo of all other species of the genus, appears to establish its claim to be considered a distinct species. The female (No.5) may generally be distinguished from the male by the greater breadth of the border of orange

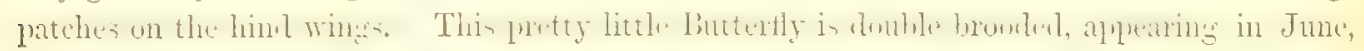
and again in August. There is some reason to fear that dealers, in their anxiety to procure as many specimens as possible, for which they get a gool price, will ultimately extinguish this species as they have done the beautiful C. Dispar; in the Fens of Huntingdon, for they have

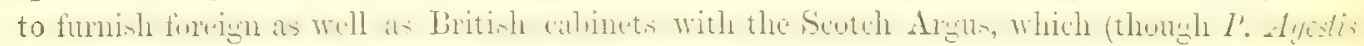
is plentiful,) is certainly unkmown on the Continent.

Mr. Logan, the enthusiastic Scottish entomologist, expresses himself very energetically on the probable extinction of the race of this elegant little insect, and in defence of his cause has even found out an objection to roadmaking, certainly never dreamed of by speculative proprietors, namely, that the one in question is likely to destroy the best known locality for Polyommatus Artareracs. He thus writes to Mr. Stainton,- "Government has agreed to construct a carriage-road between Edinhurgh and Duddington, much to my disgnust, as it is to come along the line of the present footpath, and will clestroy all the best localities for "Avlurerics." If the Govermment could be made aware of the serious injury it is about to inflict, in causing the destruction of the lest known locality for the capture of Mr. Logan's farourite Butterfly, it might yet clesist from its purpose.

* Mr. W. P. Russel has this season taken a fine fumalo specimen of C. Dispar, in St. Osjth Woods, Esser. 


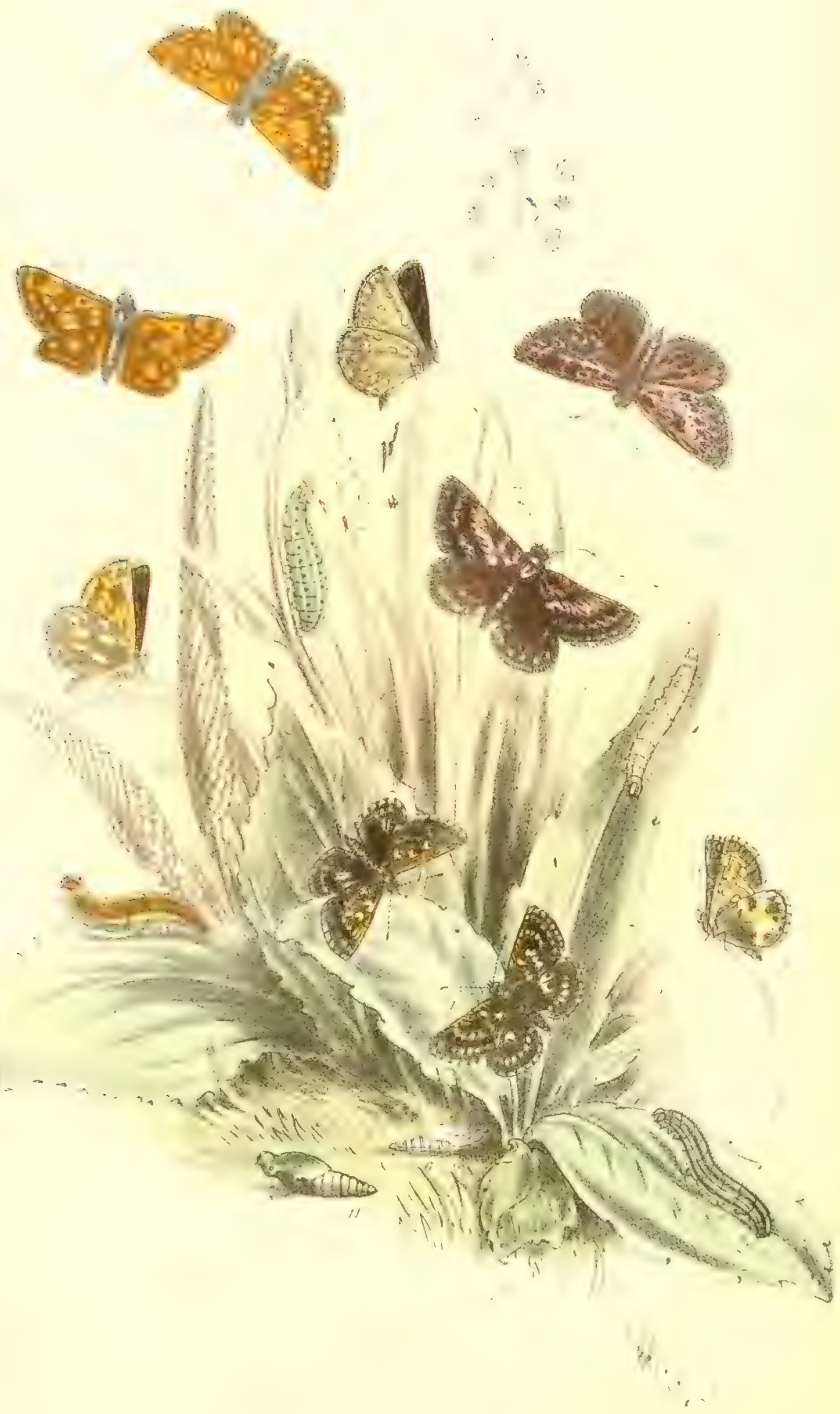


\section{PLATE XXX.}

No. 1.-The Grizzle Butterfy (Pyrgus Alveolus).

No. 2.-The Female of the Grizzle.

No. 3.-The Grizzle, showing the Under side.

No. 4.-The Caterpillar of the Grizzle.

No. 5.-The Caterpillar of the Grizzle preparing to undergo the clange to the Chrysalis.

No. 6.-The Chrysalis of the Grizzle.

No. 7.-The Dingy Skipper Butterfly (Nisoniades Tages).

No. 8. -The Female of the Dingy Skipper.
No. 9.-The Dingy Skipper, showing the Under
sile.

No. 10.-The Caterpillar of the Dingy Skipper.

No. 11. -The Chrysalis of the Dingy Skipper.

No. I2.-The Chequered Skipper Butterly (Cyclopedes Paniscus).

No. 13. -The Female of the Chequered Skipper.

No. 14.-The Chequered Skipner, showing the Under side.

No. 15. - The Caterpillar of the Chequered Skipper.

THE Fifth Family of Rhopalocere, or Butterflies, is that of the IIspericle, contrining a small group of insects, which by the structure of the antemna, and other characteristics, form a natural link between the last group of Butterflies and the first group of Moths. The IIesporilce have the head remarkably broad, and the antemme inserted on eaclı sicle, instead of being very near together as in other Butterflies. Some of the species also carry their wings horizontally when in repose, after the manner of Moths. The Caterpillars have the heal large, as in the perfect insect, and they live in rolled leaves, in the manner of certain Moths; and they also resemble them in forming a slight cocoon, which is rarely the habit of the larvo of true Butterflies. There are four British genera, containing seven species. All thesc are of comparatively

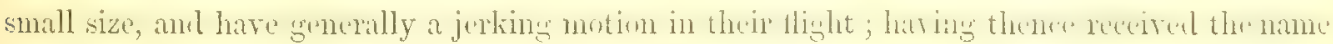
of "skippers," by which they are popularly lnown to collectors.

The genus Pyrgus. The antenure of this genus have the club gradually formed, but not hooked at the tip like some others. The wings are rounded, have deep chequered fringes, and are deflexed in repose. The Caterpillars are leaf rollers, and the Chrysalicles are formed in a slightly webbed cocoon within the curled leaf that has served as the abode of the Caterpillar. There is but one British species.

Pyrgus Alrcolus (the Grizzle, Nos. 1 to 6). This is a common insect, especially in and near woods. The Caterpillar feeds most commonly on the wild Raspberry (Butus Itleus) in April, and again late in the summer, and is to be found within rolled leaves held together by a wel).

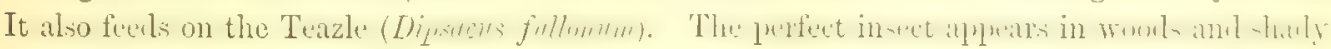

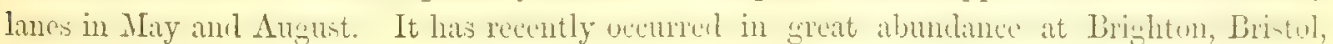
Epping, and other places.

There are several rather curions varieties of this species, the most permanent of which is one in which the white marks towarls the tips of the fore wings rum into one great irregular patch leaving only the veins dark, while in the lind wings the white marks are smaller and

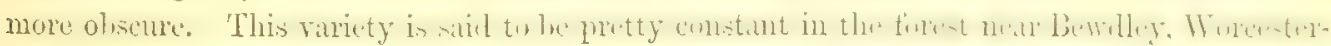
shire, and occurs oceasionally in many other localities more irregularly and more sparingly.

The genus Nisoniudes. In this genus the antenna are rather longer and more slender than 
in the preceding, and have the club attenuating to a point at the tip. The wings are horizontal or deflexed in repose, never being held erect, as is common with true Butterflies. We have but one British species.

Nisoniades Tages (the Dingy Skipper, Nos. 7 to 11). This insect is not nenr so common as the preceding, but is yet found in some plenty in various localities. It is double brooded. The

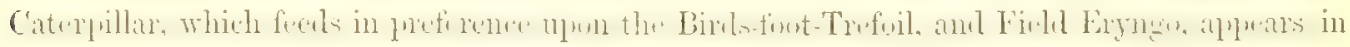
June and September; the perfect insect in May and August. It is found most frequently on the slopes of hills, and in dry exposed places near woods. Bromsgrove, in Worcestershire, and Dovedale, in Derbyshire, are mentioned as places where it has been recently captured in sufticient plenty. The Rev. F. O. Morris informs us, that it is found in great abundance in Ireland, at Artrahan, near Galway.

The genus Cyclopedes. The antennio of this genus are short and stont, and the club thick but not hooked at the tip. The front wings are long in proportion to the hinder pair. The sexes do not differ in colour.

Cyclopedes Paniscus (the Chequered Skipper, Nos. 12 to 15). This pretty species is very local, but occasionally abundant in its favourite localities. The Caterpillar (No. 15) feeds upon the Plantain (Plentugo major), and appears in September. The Chrysalis remains dormant during the winter, the perfect insect appearing in the following June. It is said to be still found in profusion in its old locality, Monk's Wood, Hants, and in a wood near Oundle, Northamptonshire; and many other localities are recorted in which it may be taken in most seasons. 



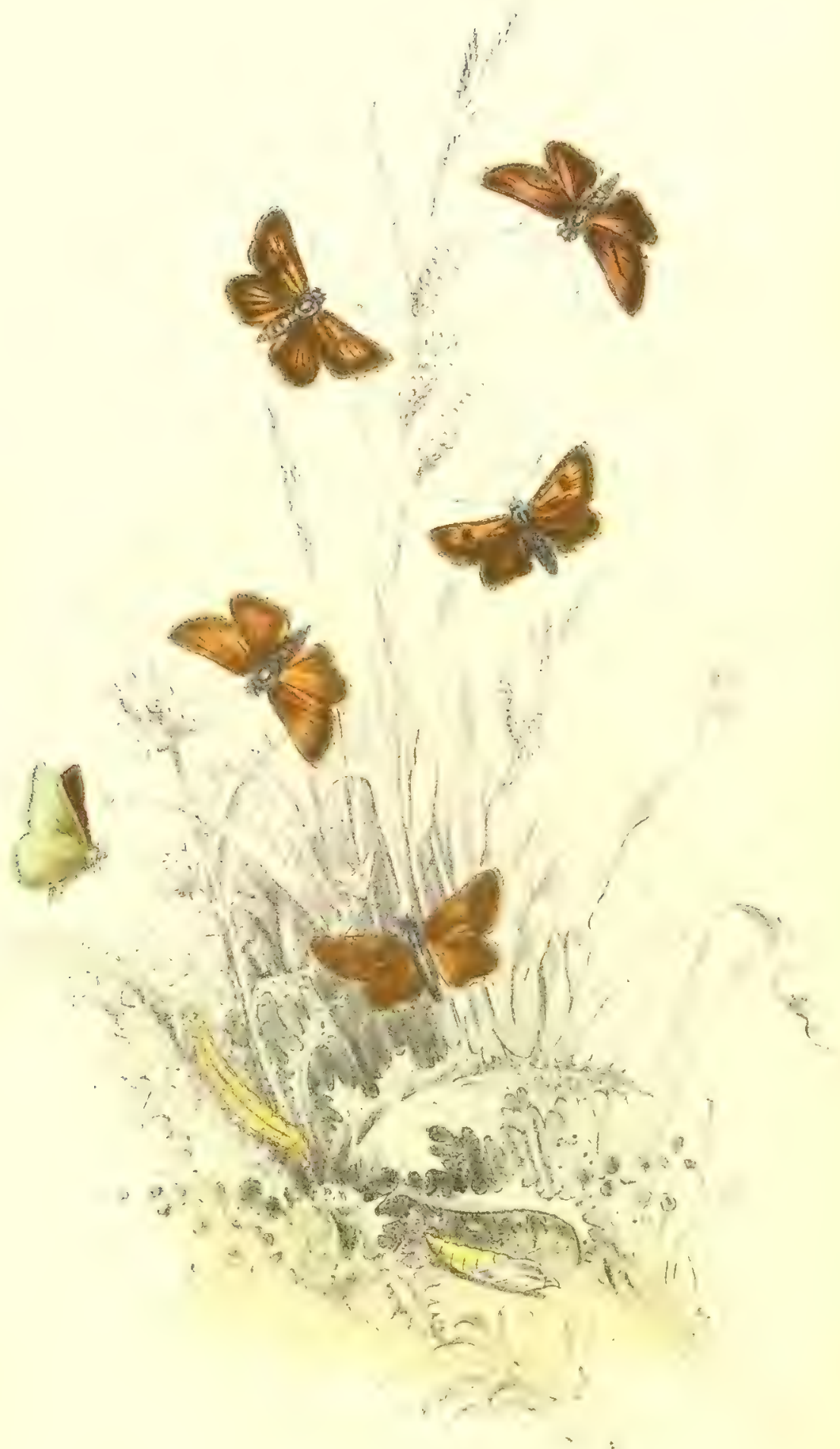




\section{PLATE XXXI,}

\section{No. 1. The Lulworth Skipper Butterfly (Pamphita Actoon).}

No. 2.-The Female of the Lulworth Slipper.

No. 3.-A dark variety of the Lulworth Shipper.

No.4.-The Small Skipper Butterfly (Pamphila Linea).
No. 5.-The Female of the Small Shipper.

No.6.-The Small Skipper, showing the Under side.

No. 7.-The Caterpillar of the Small Skipper.

No. 8. -The Chrysalis of the Small Skipper.

Trie genus P'amphile. The insects assigned to this genus are distinguishable at once from. the other Skippers by the conspicuous diagonal line of velvety black which marks the wings of the males; also by the generally paler colours of the females, and the absence in that sex of the black mark above allucled to. The female of $P$. Linco has both pairs of wings paler than thoso of the male. The female of $P$. Syzums has the wing more chequered, as well as paler than those of the male, and the same may be saict of the female of $P$. Actcon. There is mucl less

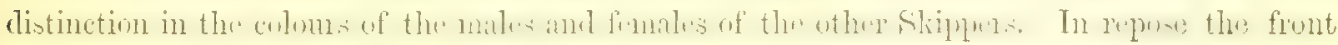
wings are often held erect, while the hinder pair remains in a horizontal position.

Pamplitic Actcon (the Lulworth Slipper, Nos. 1 to 3). This rare British insect cannot for a moment be mistaken for the common $P$. Linea by an experienced collector, though when I first took specimens of it at Shenstone, nenr Lichfiell, many jears ago, being a very young entomologist, I inadvertently placed the specimens in my collection as varieties of $P$. Linca, not being at that time acquainted with the other species. The Caterpillar is mknomn, but, as Mr. Stainton states, the female has been seen to deposit its egrgs on the Woad-reed (Culamargrostis epigejos). The perfect insect appears in July and August, and with the exception of the specimens taken by myself at Shenstone in 1835, (where I have not hearl of any sulbsequent specimens being captured, none have been taken in England except at one particular spot on the coast of Dorsetshire, Lulwortli Cove, where it was first discovered hy Mr. Dale, in August, 1832. As an entomological prize, it was no doubt pursued there pretty actively by the

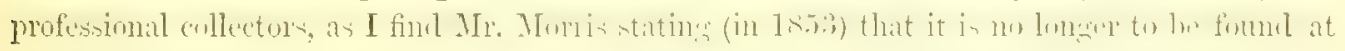
the precise part of the coast where it was first discovered, but that it was still plentiful at the

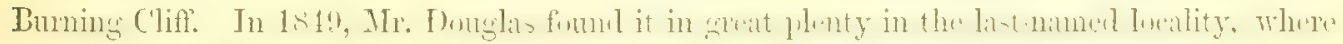
he captured above a hundred specimens in a very short time, often sweeping five or six into his net at once. Ho states at the same time that he ras unable to trace the cruse of the appearance

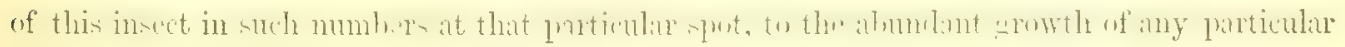
plant suitalule for the food of the larve.

The ground colour of the wings of $P$. Actaon is mucle darker than in $P$. Lined, the bright orange brown of the last-named only appearing in lighter patches in the centre of the fore wings. The female is much lighter than the male, and the wings of a nearly equal tone of orange brown all over, very closely rescmbling the colour of the female of $P$. Lined. No. 3 is a curious dark variety of the male, which, exeept in the general dark colour, approaches very nearly to dark varieties of $P$. Linea. 
Pamphila Linec (the Small Skipper, Nos. 4 to 8). This common and pretty species is abundant everywhere at the season of its annual appearance. It often finds its way even into

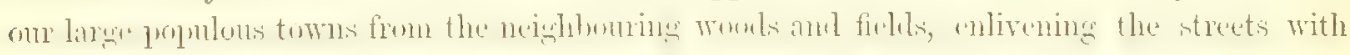

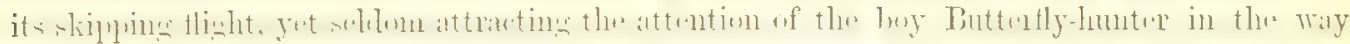
that a stray specimen of one of the Garten Whites never fails to do.

The Caterpillar (No. T) is said to feed on Grisses; and possibly also on the foliage of Thistles, as the perfect insects are generally found thuttering in great numbers over places where those plants are abundant. It is found in July.

The perfect insect appears in August, being rather Iater than the rare P. Actcon. Plymonth, Brighton, and Worcester, are places where it has been recently observed in the greatest abunrance. 



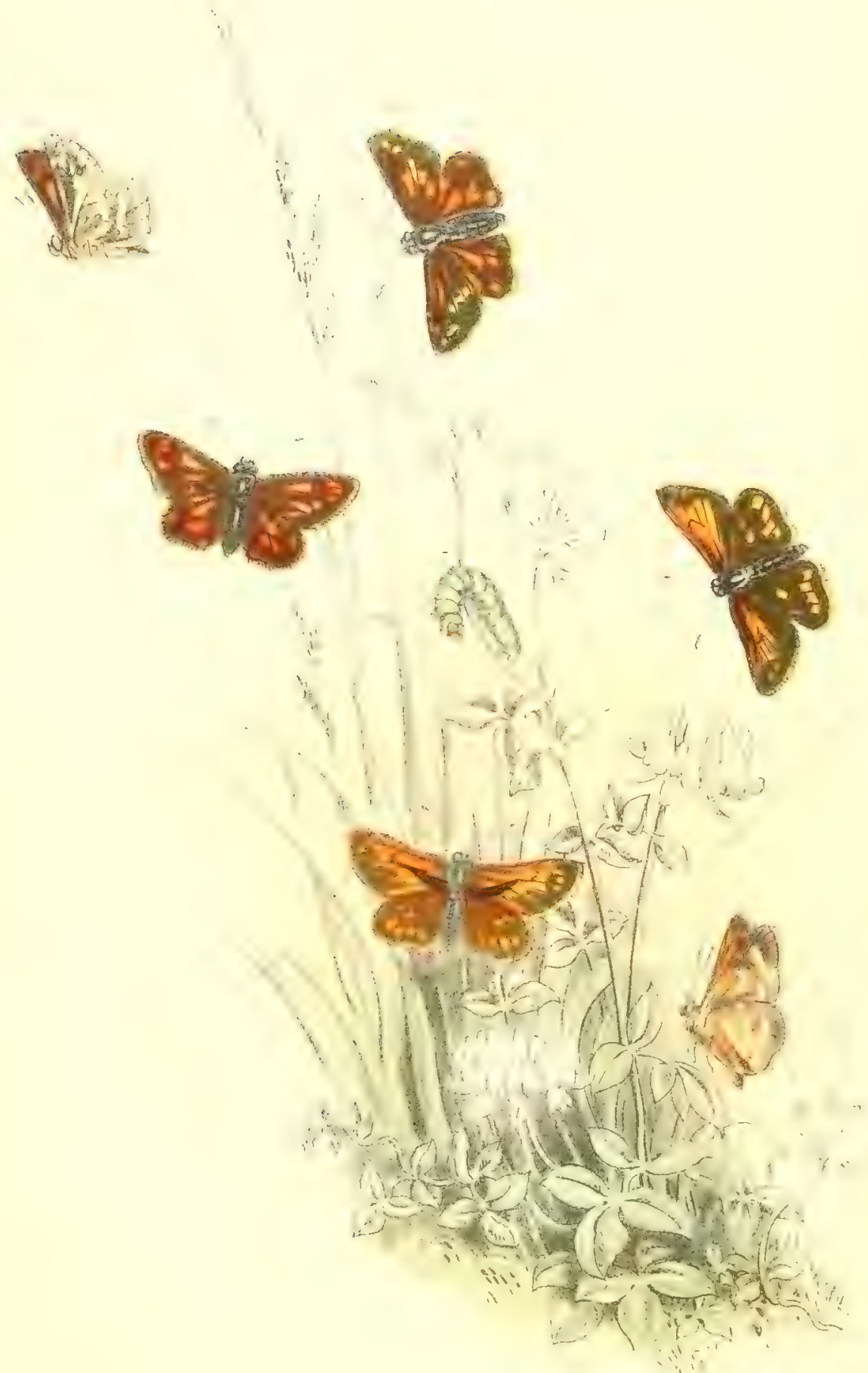




\section{PIATE XXXII.}

\section{No. 1.-The Largo Skipper Butterfly (Pampkila \\ Syluanus).}

No. 2.-The Female of the Large Skipper.

No. 3.-The Large Slipper, showing the Under side.

\author{
No.4.-The Perl Skipper Butterfly (Pampliza \\ Comma).
}

No. 5.-The Female of the Pearl Skipper.

No. 6.-The Pearl Skipper, showing the Under side. No. 7.-The Caterpillar of the Pearl Skippor.

Pamphila Sylvanus (the Large Skipper, Nos. 1 to 3). This species, which is the largest

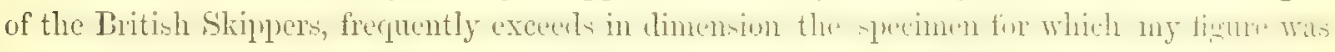
drawn. I have seen specimens measuring fully an inch and a-half from tip to tip across the front pair of wings.

The Caterpillar is described by Zeller as being of a dull green, speckled with black, with a dorsal line of darker colour, and having underneath, on the tenth or eleventh segments, white transverse spots. It feeds on the Meadow Soft-grass (Holcus lanatus), and also on other Grasses, in May; and probably appears again in the autumn, as the species is undoubtedly double brooded.

The perfect insect appears in May and again in August, the early brood resulting from the

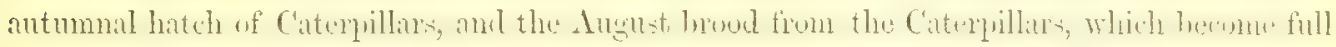
fed towards the end of May.

It is very widely distributed, and always more or less abundant, frequenting in preference the borders of woods and shady lanes; but being also found in open parts of the country. It

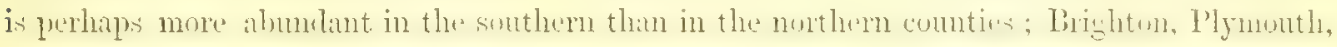

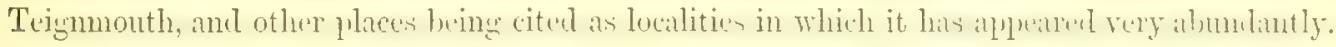

Pamphila Comma (the Pearl Skipper, or Silver-spotted Skipper, Nos. 4 to 7 ). This is a very local species, but plentiful in places where it occurs. It is clistinguished from all the other species of this pretty genus hy the pealy or silvery spots by which the mule side of the wing; (No.6) are conspicuously marked. It however accords perfectly in general character with its congeners, the male being distinguished by the short black diagonal streak, and the female (No. 5) by the lighter tone of the ground colotr of the wings, their more speckled appearance,

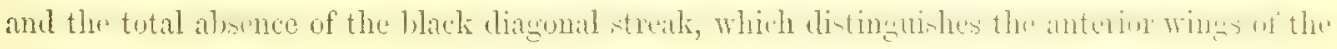
other sex.

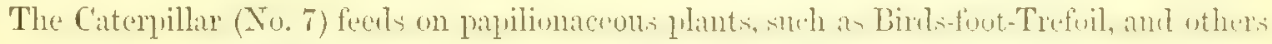
of that family. On the Continent it is known to feed on the Coronille varic. It first appears early in June, and is full fed about the middle of July.

The perfect insect is found in Augrust; frequenting in greatest abundance chalky districts in open or elevated situations. The clalk downs in the neighbourhood of Lewes, Sussex, are recorded as a locality in which it has been recently very abundant. Towards the north it is

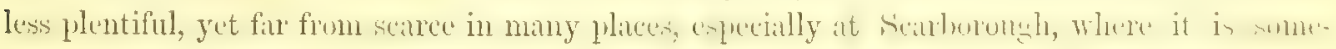
times tolerably plentiful.

Having now completed the description and illustration of the whole of our Xative Butter-

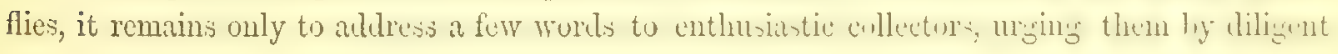


olservation and research, to cmlenvour to fill m, tho lacmir which still cxint in the listory of the preparatory stages of some of the most conspicuous species.

Considering that we can scarcely reckon more than sixty species, and that we have perhaps donble that number of good field Entomologists at work every season, (that is about two or perhaps more to each butterfly,) it appears strange that any stage of development of any single species should still remain unknom to us. Yet such is the fact, for we are as yet totally macquainted with the Caterpillar stage of the beantiful and conspicuous insect, lnown as the "Small Copper," and several other species which are equally common and well known in their

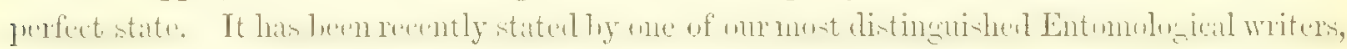
that we positively know more of the tranformations of the obscure and minute British Moths,

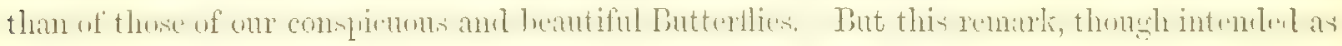
an honest incentive to research, is rather a bold exaggeration; for while we are ignorant of the larvo and pupa stages of our Butterflies only in a small mumber of instances, in the case of the small Moths, we know nothing of the preparatory stages of much more than half their number.

Mr. Logan, in Scotland, has recently done much to investigate the transformations of some of the species which are in Scotland, and has published figures of the Caterpillars of several, which were not before lnown. I hope that his successful example may stimulate the exertions of some of our English Entomologists, and that before many more seasons hirre passed, we shall be able to produce a really "complete" history of our British Butterllies in all their stages.

H. N. H. 


\section{INDEX OF TIIE GENERTO AND SPECIFIC NAMES OF BRITISII BUT'TERFLIES.}

$\Lambda$.

ApATURA Iris, I9, 20

Aporia Cratregi, 5

Arge Galathea, if

Argymis Adippe, 33

$\begin{array}{ll}" & \text { Aglaia, 2I } \\ " & \text { Euphrosyne, 35, 36 } \\ " & \text { Lathonia, 33, 34 } \\ \text { "Paphia, 29 } & \text { Selene, 35 }\end{array}$

C.

Chrisopitanus Chryseis, 46

$$
\begin{array}{ll}
, & \text { Dispar, } 48 \\
, & \text { Hippothoë, } 46 \\
, & \text { Phleas, } 45,46 \\
\text { Ë } & \text { Virgatrer, } 47
\end{array}
$$

Colias Ëdusa, 3

, Hyale, 3, 4

Coenonymplia Iavus, I7 I'amplilus, 17

Cyclopides Paniscus, 60

Cynthia Cardui, 2 I

E.

ENODIA Hyperanthus, I5

Erebia Blandina, I6

, Cassiope, I6

,2 Ligea, 15, I6

Euchloe Cardamines, Io
G.

Gonepteryx Rliami, 2 Grapta C-album, 27, 2S

II,

Irpparcira Janira, I4

$$
\text { ", Semcle, I3 }
$$

L.

LAsiomata Egeria, I I, 12 Megara, I2

Leucophasia Sinapis, ro

Limenitis Sibilla, Is

M.

Melitas Artemis, 39

, Athalia, $3^{8}$

" Cimxia, $37,3^{8}$

N.

Nemeorius Lucina, 40

Nisoniades Tages, 60

$\Gamma$.

Pamphila Actron, 6r

$\begin{array}{ll}" & \text { Conma, 63 } \\ , & \text { Linea, 62 } \\ & \text { Sylvanus, 63 }\end{array}$

Papilio Machson, I, 2

Picris Brassicre, 6

, Daplidice, 9

, Napi, 8

, Tape, 7

Polyommatus Acis, 50

$\begin{array}{ll}, & \text { Adonis, 53 } \\ , & \text { Agon, 55 } \\ " & \text { Agestis, 55, 56 } \\ , & \text { Alexis, 53, 54 } \\ " & \text { Alsus, 50 } \\ " & \text { Argiolus, 49 } \\ " & \text { Arion, 51 } \\ " & \text { Artaxerxes, 5S } \\ " & \text { Corydon, 51, 52 } \\ \text { Salmacis, 57, 5S }\end{array}$

Pyrgus Alveolus, 59

\section{T.}

TiIecla Betula, 4I

, Pruni, 4i

,2 Quercus, 43

,, Kubi, 43

,, IV-album, 42

V.

VANEsSA, Antiopa, 23, 24

, Atalanta, 22

, Io, 23

"I Iolychloros, 25

Urticre, 27

\section{INDEX OF POPULAR NAIES OF BRITISII BUTTERFLIES.}

$\Lambda$.

ARGUS's, 55-5S

Azure Blue, 49

1..

BLACK FIair-streak, 42 Black-veined White, 5

Blues, 49-55

Brimstone, 2

Brown Argus, 55, 56

Brown IIair-streals, 41
C.

Cambertvell Beauty, 23, 24

Chequered Skipper, 60

Clifden I3lue, 53

Clouded Vellow, 3

Comma Butterfly, 27, 28

Common Blue, 53, 54

Chalk Ifill Blue, 51,52

Copper Buttertly, 45

Coppers, $45-4 \mathrm{~S}$

D.

DARK Argus, 57, 5 S

Dark Green Fritillary, 3 I
Dark IIair-streak, 4I

Dark Under-winged Copper, 46 Dinsy Skipper, 60

Duke of Burgundy Fritillary, 40

F.

Fritillaris, 29-40

G.

Gate Keeper; I4

Glanville Fritillary, 37

Grayling Butterfly, 13

Greasy Fritillary, 39 
Great Cabbare-White, 6

Great Swallow-tailed, I

Great Tortoise-shell, 25

Green Chequered White, 2, 10

Green Hair-streak, 44

Green-veined White, 7, S

Grizzle Butterlly, 59

II.

IIAIR-STREAKS, 4I-44

Ieath Fritillary, $3 \mathrm{~S}$

Iigh Brown Fritiliary, 33

L.

LARGE Blue, 51

Large Copper, 47-4S

Large Skipper, 63

Luworth Skipper, 6I

MI.

MARbLed White, II

Minsin Ringlet, I 7

Mazarine Iilue, 50

Micadory liown, 14
O.

ORANGE-TIS, IO

P.

PAinted Laty, 2I

l'ale Clouded Y'ellow, 3

I'cacock, 23

Penrl-Burclered Fritillary, 35, $3^{6}$

Pearl Skipper, 63

I'urple-etgerl Copper, 46

l'urple Emperor, in, 20

I'urple Ifair-stronk, 43

\section{Q.}

QUEEN of Spain Fritillary, 33, 34

li.

RED Admiral, 22

Ringlet Butterly, I5

Ringlets, $15-17$ $\therefore$

Scarce Copper, 47

Scotch Argus, 15, I6

Silver-studded Blue, 55

Silver-washed Fritillary, 29, 30

Skippers, 6o-n-63

Small Blue, 5o

Small Cablage-White, 7

Small IIeath, I 7

Small Pearl Dorclered Fritillary, 35

Small Ringlet, If

Small Scotcl Argus, 59

Small Skipper, 62

Small Tortoise-she1l, 27

speckled Wood, I2

T.

TorTOISE-SIIELLS, $25-27$

IV.

WALL Butterfly, I2

White Admiral, is

Whites, 5-II

IVood White, Io

\section{INDEI OF FAIILIES AND SUB-FAMLIES OF BRITISII BUTTERELIES.}

\author{
Argyrunicli (Sul-Family), ag \\ Erycinicloc (Family), 39 \\ Hesperikle (Family), 59 \\ Lycenicle (Family), AI
}

Nymphalidx (Family), II
Nymphaluli (Suls-Family), it
Papilionida (Fannily), I
Papilionicli (Sub-I'amily), I

Nymphalidx (Family), II

Papilionici (suld-Imily),
Pieridi (Sub-Family), 5

Rhodoccridi (Sub.Family), 2

Satyricli (Sub.F amily), I I

Vamessidi (Sub-Family), 2 I 


\section{TIIE BEST METHODS OF PRESERVING BLTTERFLIES AND MOTIS ;}

$\triangle N D$ OF

\section{REARING THEM FROM THE CATERPILLAR OR THE EGG.}

To capture Butterflies and Moths in their perfect or winged state, it is necessary that the cullector he provided with a small gatuze net, attached to a hop of strong iron wire at the end

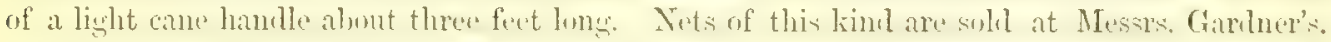
in Hollum, and Mesice. Shepherd's, in the Straml; who manufueture articles of this kind of better quality than can possibly be the result of home faluriention. Boxes lined with cork for securing the insects when taken, as well as many other entomological conveniences, are to be purchased at those establishments, and also at many others of the same kind.

The collector will soon find out the hour of the day at which the insects he is seeking generally appear on the wing; and it is almost useless to seek them at any other. It is also in vain to attempt collecting insects on the wing in a cold casterly wind, especially such as fly early in the moming, or towards the hours of evening. Butterflies, with very few exceptions, will be found more plentiful in the sumy hours preceding, and those immodiately following the heat of the day: while for a short period, during the sun's greatest heat, they disappear for a short time. Some fly principally in half shade of woods and deep lanes, w'ille others seek in preference the bright nem sunlight. Others take their flight high ahowe the tons of the luftiest Oaks, as the Purple Emperor, and these must either be secured by means of a small light net at the end of a very long rod, or some little stratagem must be had recourse to in order to effert a capture. I reollent an experiencerl Lepirtopterist telling me that he took his two fine specimens of the Purple Emperor in an Oak wood, rather Iate in the day, after a morning of fruitless attempts, by watching the trunks of the trees as a storm was coming on. He had hearl that these insects, on the approan of a storm, descented from the recrion of their lofty flight to seek shelter on the trunks and beneath the lower branches of large trees; and as the sky darkened, and the thunder hegan to rumble in the distaner, he fomm that his information

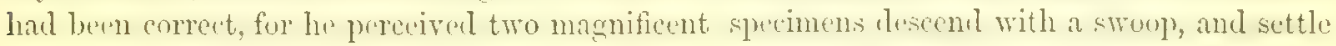
upon an old gray trunk close to him, where he was so fortunate as to capture both.

As an example of what an earnest collector may expect in an excursion of a few days, even without much experience, I append a letter received this season from a young collector, in which it will be seen that, as far as Purple Emperors are concerned (from knowing a good locality to go to), he was loy far more succesful than my friend of the thundrestorn ; ant his other captures form a very tempting list.

"I captured on Friday last, in St. Osyth Woods, Essex, a very fine specimen of I Tuncssa Antiopa; the borders of the wings are a rich cream-colour, the points of the upper wings are slightly marked with blue. I took it off a bramble. I also took at the same place a female specimen of the Large Copper (Chysophanus Dispar). In the neighbourhood of this place (Monk's Eleigh) and Savenham, I have found this summer a greater number of varicties than usual; amongst others, Chrysophanus Phtcas (female); C. Virgaurex; Thecla IV-album ; Meliten Cinxia; Argynnys Adippe; A. Lathonic, A. Paphiar; Grapte C-album; Vanessa Urtice; Cynthia Curctui; Apatura Iris (of which I also took thirty at St. Osyth); Limenitis Sililla; Arge Galathea; Leucophasia Sinapis; Papilio MTachaon; Colias IIyale (two taken this morning); and Aporia Cratogi. The Vanessa $I_{0}$ is extraordinarily numerous this year, as much so as Picris Brassice."

To take Moths on the wing, other devices must be had recourse to ; a few, it is true, fly by lay in the hright sunshine like Butterflies, hut hy far the greater mumber take their thish at early dawn, in the dusk of the evening, or during the successive hours of the night, each species having a special-period of activity, from which it does not depart.

The following are a few of the species which may be attracted, in succession, by a lighted

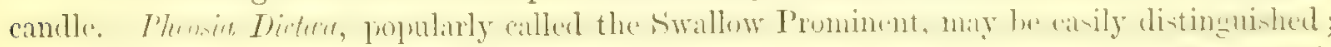
in its fitful flight when agitated by the candle, this inscet continually larts towards the gronnd, 


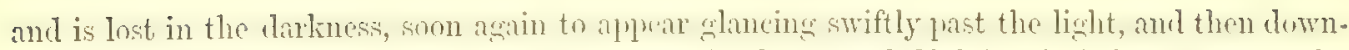
ward into the shade, as before. Agrotis corticea, the Heart and Club Moth, is less fleet on the wing than the preceding, and instead of flying downwards towards the floor, invariably rises

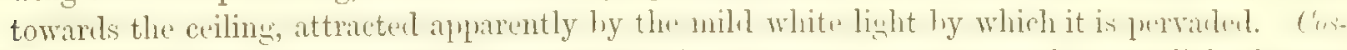
mia Pyoline (the Lunar-spotten Pinion IIsth), if it enter a room attracterl ly the light, is very wild and irmegular in its thight, hashing from the candle to the ceiling, and from the ceiling to the floor. Thongh this insect is by no means common, I lave taken it more than once in a lighted room, always, I believe, on a miny evening, and towards the end of July. Clisiocompo Neustria, the Lackey Moth, is as abundant as the last described species is rare, and yet it is seldem seen in the perfect form, as it is a swift night-flyer. This moth, on entering a room,

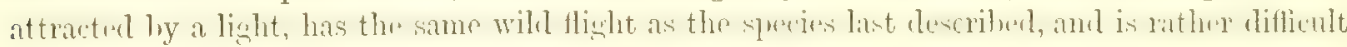
to capture, even with the aid of a proper net. Later in the season may be talien Petasia Cassinea, popularly known as the Sprawler, which, like the last, is much more rare in the winged state than in the Caterpillar stage of its existence. It is, however, often attracted by a light, when its flight becomes random, dashing heedlessly on all sides through the flame of the candle up to the ceiling, or down to the floor. This species seldom appears before November, and is often found as late as December. It is late in the hour of its Hight, as well as in the season of its appearance, often retarding its visit to the expectant candle till one or two in the morning. Still later in the year appears the remarkably elegant December Moth, Facilocampa Populi, which is ensily attracted by light, and, if any be in the neighloourhood, they will make their appearance hetween the hours of seven and ten on fivourable evenings.

Sitting in a well-lighted room, with the window open to the dark garden, a watcher, active with the net, may capture in succession many species in a single night. But before the shades of evening have sunk into darkness, the collector should have perambulated, net in hand, the most shady walks of his garden, beating the shrubs with a stick held in lis left hand; when he is sure, at the right season, to meet with the male Ghost Moth, flitting white and bright before him, and then vanishing as suddenly, as the dark under-side of the wings meet the eye instead of the snow-white upper surface. Then there will be the Phantom Moth, like the miniature skeleton of some delicate insect, haming the spot where it had once flitted in more substantial shape. This is the "White Plume," sometimes called the Skeleton Moth. These and many move rare and handsomer species will reward persevering pursuit on a favourable evening.

A very successful method of capturing night-flying Moths, is that of tempting them to settle in a certain spot by a bait of sugar. The sugar is reduced to a thick solution hy the addition of water, and then brushed upon the trunks of trees, old palings, \&c., in favourable situations. The baited spot must be visited once an hour or so, or the insect may have paid the visit, and again taken to flight. Some collectors place a light near the sugared trees as an additional attraction, and some add a large white sheet behind the sugared trees, upon which the light should be made to fall as brightly as possible.

At dawn of day, on a fine mild summer morning, some of the rarer Splhingitle may be taken fluttering over their favourite flowers. I took a magnificent specimen of Sphine Conrolvuli hovering over a bed of Petunias, this season.

The preservation of insects thus taken is very simple, and the best methods are perfectly known to all experienced entomologists. But I am writing for those who are at present without such experience. The Butterfly or Moth, while still in the net (which should be allowed to lie close together, so as to prevent as much as possible the movement of the insect), should be taken hold of by the thumb and finger underneath the chest, and suddenly pinclied with some little force, which immediately destroys all seusation. It may then be dropped lightly from the net, so as not to injure the delicate scales of the wings. An entymological pin* must then be passed through the thorax from the upper side, between the wings, in a perfectly

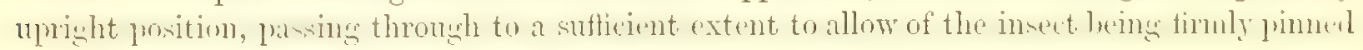
to the bottom of the cork-lined box. The same process will be followed in all subsequent captures, taking care not to place the specimens too close together in the box.

Some collectors put each insect, if a particularly fine specimen, or very rare species, into a

* Pins that do not corrode, and which are sold by all rendors of collecting apparatus. 
separate hox, touching the lowtom of it with a single drop of chloroform, which has hien fomnd to prevent any retum of wan-ation, or any fluttering af the wines hy which the ir heanty minht be seriously injured.

On arriving at home, the insects should be carefully set out in the form they are intended

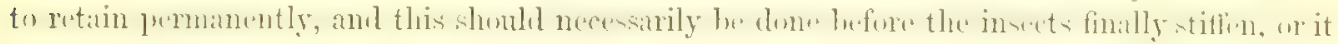
becomes difficult to manage them so well, though an exposure to the steam arising from a cup of hot water will generally restore a temporary limpness. The process of "setting out" must, of course, be done with neatness and care, so as not to injure the wings, or Treak the antenne. A board covered with a coating of cork must be provided, in which there are grooves ruming across of greater or lesser depth. The insect may then be fixed by the pin into the groove according to the thickness of the body. The body of a Butterfly being generally small, the groore need not be deep. The wings are then to be spreat ont on the hoard on either side, level with the body and fully expanded. They are to be fixed in that position by means of strips of thin and very smooth cardhoard, pinned down over them sufficiently close to hold them in the position required, but not so close as to injure the delicate scales of the wings. In a few days the insect will have stiffened in the position in which it has been fixed as described, and which it will permanently retain. It should then be removed to the cabinet in which it is to be preserved. In order to preserve the specimens in a cabinet from the attacks of minute parasitic insects, a small piece of camphor is generally fixed in the corner of ench drawer. If what is called the grease should attack the insects in a cabinet, the best mode of restoring the insects attacked to their original condition is the following. The grease generally appears in largebodied Moths or Butterflies, giving the bodies the appearance of having been soaked in oil ; and this appearance soon spreads to the wings, utterly destroying the beanty of the specimens. To restore an insect thus attacked, fix it on a piece of cork weighted with lead, or something heavy, and place it at the bottom of a saucer or any similar vessel. Then fill the saucer with benzone,* entirely covering the insect, which will not be injured by the wetting. After five minutes it may be taken out, and the benzone, being an absorber of grease, will carry off the oily matter in the course of its own evaporation, which is very rapid. The insect will then become as beautiful as when first "set out," and may be replaced in the caloinet.

The collection of Caterpillars may be commenced as soon as the leares begin to appear, and may be contimued till the end of September or October, as there are many double-brooded

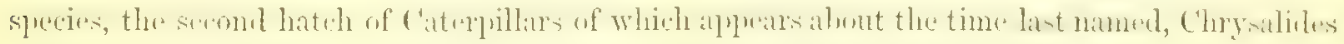
of which remain dormant through the winter. Detached trees may be well shaken after a white table-cloth has been spread beneath, and a number of Caterpillars, difficult to discover in any other way, may thus be secured. Hedgerows may be beaten over an inverted umbrella for the same purpose. A careful search among low-growing plants will, however, be necessary to secure

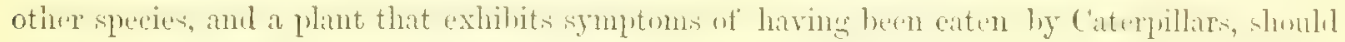
sometimes be pulled up by the roots, and the root well examined, as the night-feeding Caterpillars often take shelter beneath the surface of the soil during the day, and conceal themselves among the loose roots; or they may sometimes be found hidden among the decayed leaves about the base of the main stalk of the plant. The Caterpillars of most of the Meadow brown Butterflies and many Moths, are grass-feeders, and yet meadow after meadow inight be looked over in vain for a single larva, as in almost all cases they belong to the night-feeding class just alluded to. The truly magnificent Caterpillar of the Sword-grass Moth is, doubtless, a night-feeder, which accounts for its seeming rarity, few specimens having been seen by Lntomologists. The

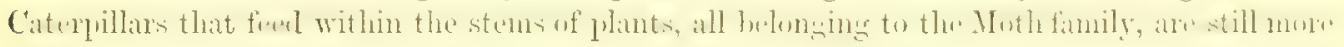
difficult to find, but their internal ravages may generally be traced by the paler or yellower green of the branch or stem, the sap of which is being consumed by an intruder; and on opening the branch he will be discovered at work; but it is better to leave him till his full growth is attained, marking the stem in some way so as to recognise it casily. The Leaf-rollers, Leafminers, and Bark and Lichen-feeders, and those that feed in cases-concealed like those of the Caddis-worm in particles of decayed wood or dead leaves, will have to be looked for very care-

* This remedy was first mentioned in a rery charming little periodical, entitled "Recreatire Science," which is always full of useful information. 
fully. When a Caterpillar or a lwool of a gregarions kimd has been discoveren, it is hetter to leave them on the branch or plant of their own selection-covering it securely with a piece of sanze-than to attempt their removal. But if at a distance from home this would le impracticable, and in that case a "rearing cage" or hox must be prepared. This is easily managed. $A$ strong box, about two feet long by one broad, should be sumk to about half its depth in the ground in some sheltered part of a garden; the lid is to be of wire-tissne such as meat-safes are made of, and ahove it is to be a sloping board or roof to shoot off the rain. The box is to be about lalf-filled with broken bits of tile and garden mould, partially covered over with moss. The food for each kind of Caterpillar placed in the box should, in order to leep it fresh, be placed in a glass phial of water in the box; and in addition to this precaution the food should he changed every day. If, however, the food be changed every day, the bottles of water may be dispensed with in most cases, though they are always of advantage. In a box of this lind, so placed, the Caterpillars have the advantage both of open air and shelter; and they either burrow in the ground at the bottom to undergo their change, or suspend themselves to some branch which should be fixed for that purpose; or they attach themselves to the sides of the box. Care must be taken to watch the box carefully at the time when Moths or Butterflies are expected to emerge from their chrysalides, as they would otherwise, when prepared to take flight, beat themselves against the wire lid and injure their wings. I have described boxes of this kind at much greater length in the "Butterfly Vivarium."*

The eggs of Butterflies and Moths may also be placed in this rearing cage, where they will hatch themselves at the proper season, and if the proper food be provided for the young brood of minute Caterpillars, they will thive well. The eggs of Moths and Butterflies may be found by watching the under side of leaves, \&c. ; when a mass of small and nearly spherical objects, somewhat less than a pin's head, are observed attached together on a leaf, placed in straight or diagonal rows with geometrical regularity, it may in most cases be taken for granted that they are the eggs in question. They are sometimes found in rings, encircling branches of slirubs, like double or treble rows of beals. But the collector will soon have an eye to perceive and recognise his game under very varied aspects and circumstances. Besides this mode of collecting the eggs, there is another. Almost every female Motlı or Butterfly that is captured, will deposit its eggs before dying; indeed, it appears almost impossible to extinguish life in the female insect till this main object of its existence-the deposition of its eggs-has been effected. Iare and beatiful Caterpillars may often be raised in numbers from the eggs of a captured Motl, which it is difficult to procure in any other way, their natural haunts and habits being unknown.

The great advantage of rearing Moths and hatching Caterpillars in this way is-first, that the specimens of the winged insect are necessarily much more perfect than those captured during their flight; secondly, that the Caterpillars of some kinds of Moths are very common, while the Moth itself is rarely seen, and can only be procured by rearing it from the larva; thirdly, that some larve may be obtained in this way from the egg which are, as stated above, seldom otherwise seell.

I succeded in procuring some magnificent specimens of the Death's-head Moth from the Caterpillar in a rearing cage of this kind. But an amateur Entomologist writes me that for this species his own method, as follows, is better:- "Last year I took three Caterpillars of the Death's-head Hawk Moth; one I kept in dry earth, one in a box buried in the garden, and onc in a box in my study, which I regularly watered twice a week: the last succeeded admirnbly, it emerged in March; the two others appeared in the beginning of May, and were almost wortlless." The eggs and chrysalides of many fine Continental species not found in England, may be procured at Mr. Gardner's, No. 52, High Holborn-such as the Great Emperor Moth, the handsome Iutterfly Pantio Podativius, and others. I lave found great amusement and interest in rearing some of the finer Continental Lepidoptera in this manner, and then letting them fly in my garden, where they have sported for several days, and then disappeared; for it does not seem possible to naturalise any new species in this way. Confined to a greenhonse they might, however, exist through several generations, forming a great additional ornament, and giving quite a new source of interest to an ordinary Conservatory.

H. N.H.

* Now published by Mr. Bohn, IIemrietta Street, Corent Garden. 





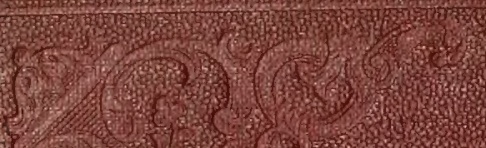

$(-5)+1$

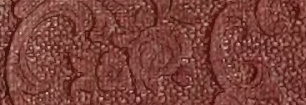

$2=0$

(5)

(

sest

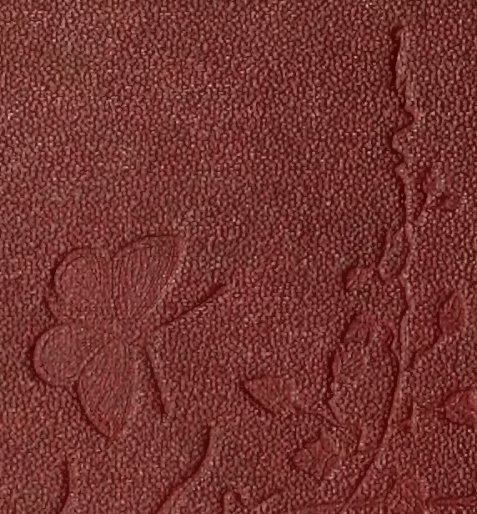

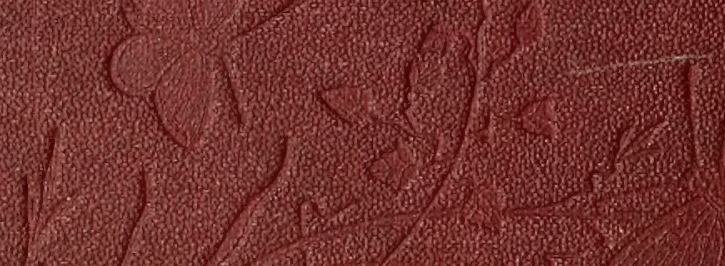

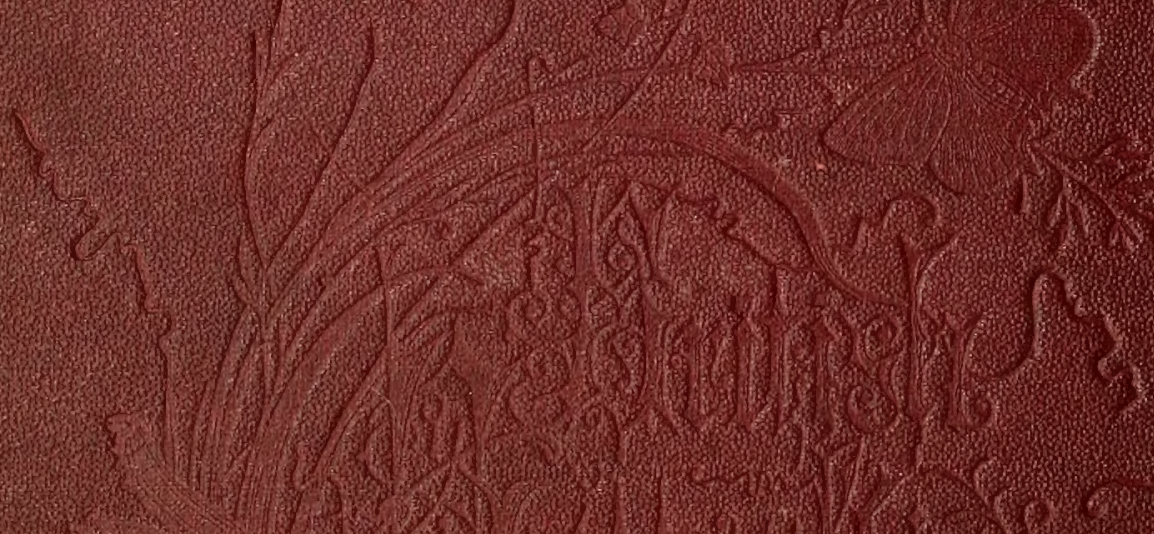

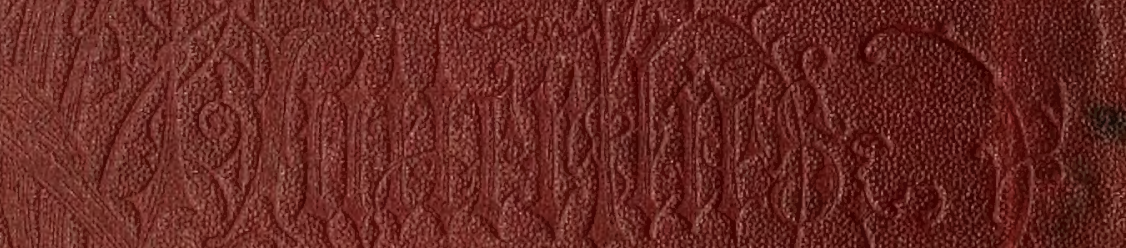

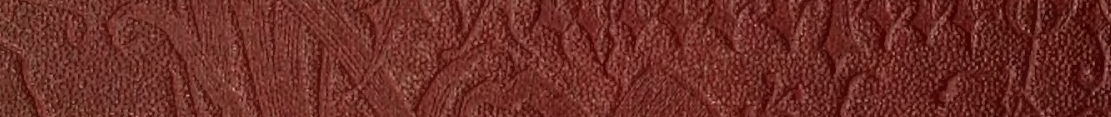

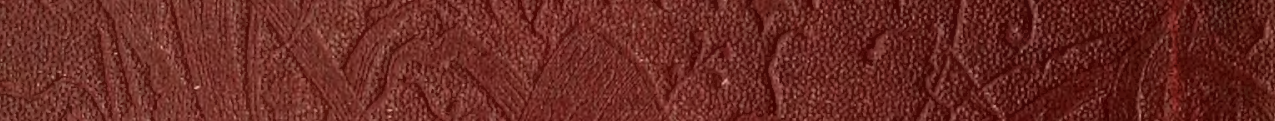

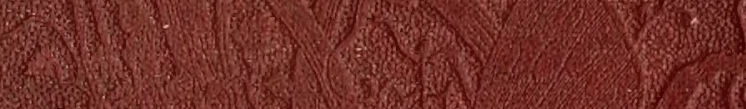

che 15.70

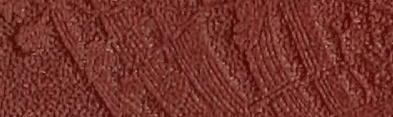

in

$(4,5)=2$

(11) 2010

3) $=12$

(7)

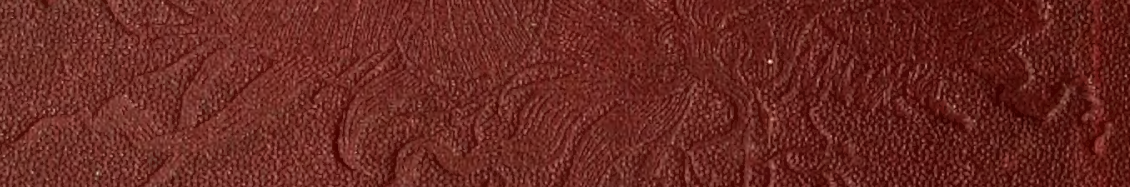
$\left(\begin{array}{cc}2 \\ 4\end{array}\right.$

$\{(-3)(3)$

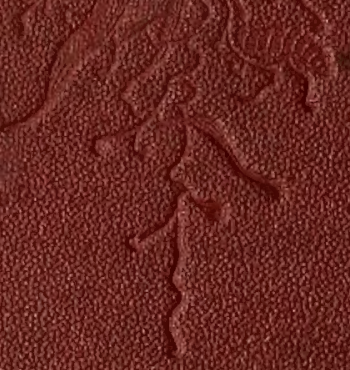

